\title{
DENITRIFICATION OF ACID WASTES FROM URANIUM PURIFICATION \\ PROCESSES
}

\author{
F. E. Clark
}

C. W. Francis (ORNL)

H. C. Francke

J. W. Strohecker 


\section{DISCLAIMER}

This report was prepared as an account of work sponsored by an agency of the United States Government. Neither the United States Government nor any agency Thereof, nor any of their employees, makes any warranty, express or implied, or assumes any legal liability or responsibility for the accuracy, completeness, or usefulness of any information, apparatus, product, or process disclosed, or represents that its use would not infringe privately owned rights. Reference herein to any specific commercial product, process, or service by trade name, trademark, manufacturer, or otherwise does not necessarily constitute or imply its endorsement, recommendation, or favoring by the United States Government or any agency thereof. The views and opinions of authors expressed herein do not necessarily state or reflect those of the United States Government or any agency thereof. 


\section{DISCLAIMER}

Portions of this document may be illegible in electronic image products. Images are produced from the best available original document. 
Reference to a company or product name does not imply approval or recommendation of the product by Union Carbide Corporation or the U.S. Energy Research and Development Administration to the exclusion of others that may meet specifications.

Printed in the United States of America. Available from

National Technical Information Service

U.S. Department of Commerce

5285 Port Royal Road, Springfield, Virginia 22161

Price: Printed Copy $\$ 5.45 ;$ Microfiche $\$ 2.25$

This report was prepared as an account of work sponsored by the United States Government. Neither the United States nor the Energy Research and Development Administration, nor any of their employees, nor any of their contractors, subcontractors, or their employees, makes any warranty, express or implied, or assumes any legal liability or responsibility for the accuracy, completeness or usefulness of any information, apparatus, product or process disclosed, or represents that its use would not infringe privately owned rights. 
Date of Issue: November 21, 1975

Distribution Category: UC-11

\title{
DENITRIFICATION OF ACID WASTES FROM URANIUM PURIFICATION PROCESSES
}

\author{
F. E. Clark \\ H. C. Francke \\ Materials Engineering Development Department \\ Y-12 Development Division \\ J. W. Strohecker \\ Facilities Engineering ( $Y-12)$ \\ Support Engineering \\ C. W. Francis \\ ORNL
}

Oak Ridge Y-12 Plant

P. O. Box Y, Oak Ridge, Tennessee 37830

Prepered for the US Eneryy Research and Development Administration

Under US Government Contract W-7405-eng-26 


\begin{abstract}
Laboratory and pilot-plant investigations have shown the technical feasibility of removing nitrates from neutralized acid wastes by biological denitrification, a dissimilatory process in which the nitrate ion is reduced to nitrogen gas by specific bacteria. The process requires anaerobic conditions and an organic carbon source, as well as other life-sustaining constituents.
\end{abstract}

These denitrification studies have produced process design information on a columnar denitrification plant and on continuous-flow, stirred-bed reactors. Denitrification, using packed columns, has been found to be desirable fur suluble salts, such as those of sodium and ammonium; denitrification, using stirred reactors, has been found to be desirable for mixtures containing insoluble salts, such as those of calcium and aluminum. Hacked columns have been found to have denitrification rates ranging up to 122 grams of nitrate per day per cubic decımeter of column volume; stirred-ued reactors have been shown to havc rcaction rates near 10 grams of nitrate per day per cubic decimeter of reactor volume. The continuous-flow, stirred-bed reactors were selected for scaleup studies because of the solids-removal problems associated with packed columns when operating on feeds containing high concentrations of insoluble salts or ions which form insoluble salts with the products of the denitrification reaction.

In order to determine the effectiveness of a biological process, the specific waste stream must be considered. Minor changes in the composition of the wastes can cause major changes in the biological denitrification process. 


\section{CONTENTS}

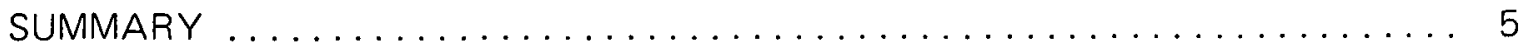

Feasibility of the Columnar Denitrification Systems $\ldots \ldots \ldots \ldots \ldots \ldots \ldots \ldots$

Stirred-Bed Reactors $\ldots \ldots \ldots \ldots \ldots \ldots \ldots \ldots \ldots \ldots \ldots \ldots \ldots \ldots \ldots \ldots$

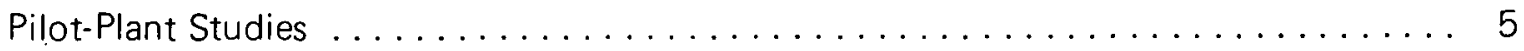

INTRODUCTION $\ldots \ldots \ldots \ldots \ldots \ldots \ldots \ldots \ldots \ldots \ldots \ldots \ldots \ldots \ldots$

ACID WASTE DENITRIFICATION $\ldots \ldots \ldots \ldots \ldots \ldots \ldots \ldots \ldots \ldots \ldots$

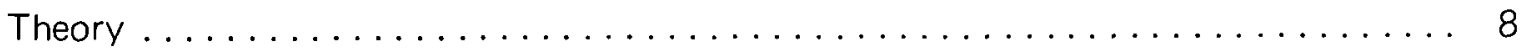

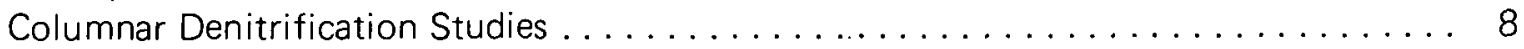

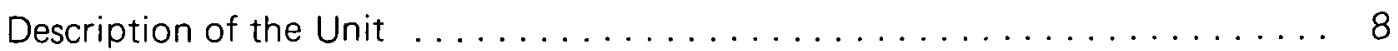

Materials and Methods ........................ 8

Method of Expressing Denitrification Rates . . . . . . . . . . . . . 9

Results and Discussion .......................... 10

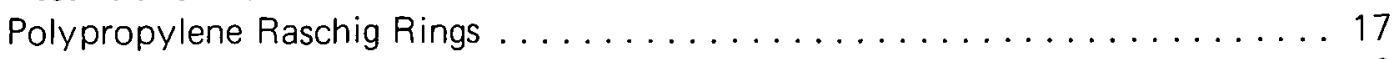

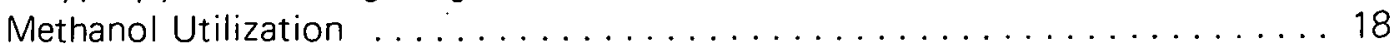

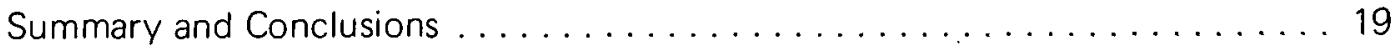

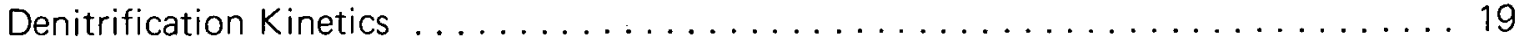

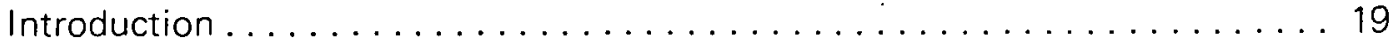

Methods and Materials . . . . . . . . . . . . . . . . . 19

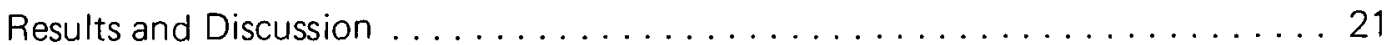

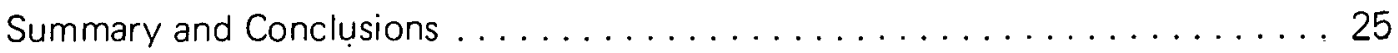

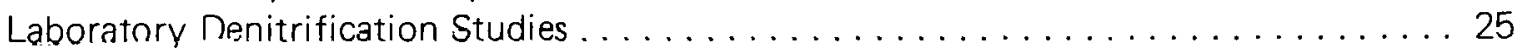

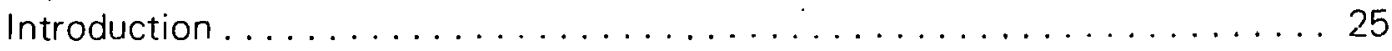

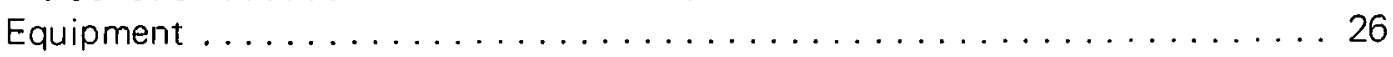

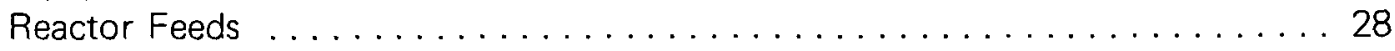

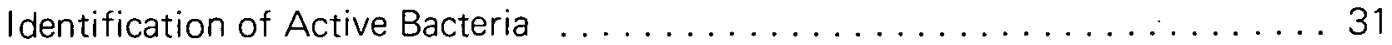

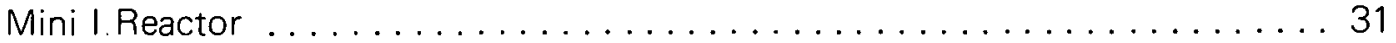

Mini II Reactor . . . . . . . . . . . . . . . . . . . . . . 35

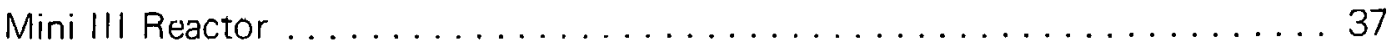

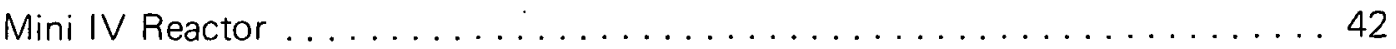

Removal of Solids ........................... 45

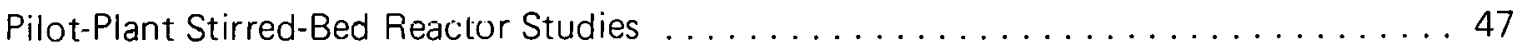

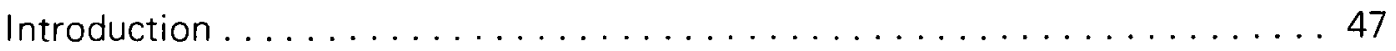

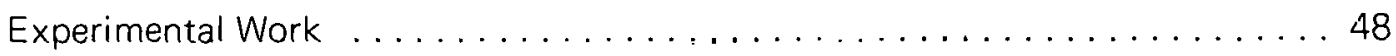

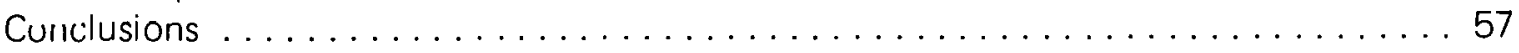

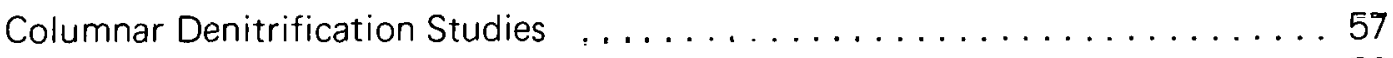

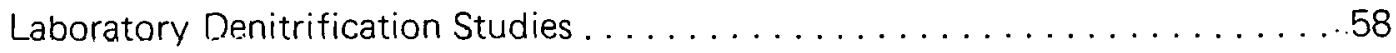

Pilot-Plant Stirred-Bed Studies . . . . . . . . . . . . . . . . . 58

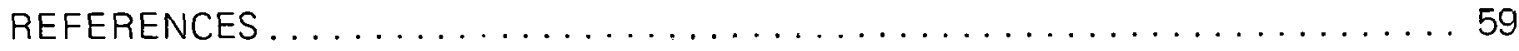

ACKNOWLEDGEMENTS $\ldots \ldots \ldots \ldots \ldots \ldots \ldots \ldots \ldots \ldots \ldots \ldots \ldots \ldots \ldots$ 


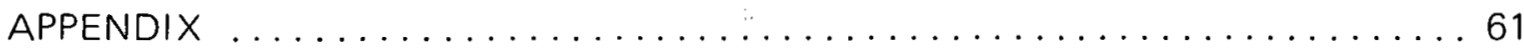

Operational Data on the Four Mini Reactors $\ldots \ldots \ldots \ldots \ldots \ldots \ldots \ldots \ldots \ldots \ldots \ldots$ 


\section{SUMMARY}

\section{FEASIBILITY OF THE COLUMNAR DENITRIFICATION SYSTEMS}

Nitrate waste streams from two uranium processes were evaluated in the columnar denitrification studies. One stream, containing high concentrations of calcium and aluminum salts, was found to be unsuitable for feed to the column. Another stream, containing high concentrations of ammonium salts, was found to be effectively denitrified using packed columns.

The packed-column studies evaluated both straight and tapered columns, with the tapered column being the preferred design. Several column-packing media were studied including anthracite coal. Carbon in the form of methanol was used in the column studies.

Denitrification-rate studies showed decomposition rates up to 122 grams of nitrate per day per cubic decimeter of column volume. Scaleup calculations indicated that a 1.2-meter-long by 8 -meter-diameter column could decompose five metric tons of nitrate per day where the inlet feed concentration would be in the range of 500 to $5000 \mathrm{~g} \mathrm{NO}_{3}^{-} / \mathrm{m}^{3}$, and the total fecd flow would be in the range of $11.6 \mathrm{dm} 3 / \mathrm{s}$, producing a cross-sectional flow in the column of $0.23 \mathrm{dm} 3 / \mathrm{m}^{3} / \mathrm{s}$. It should be noted that scaleup studies should be performed on plant waste streams to obtain engineering design information on specific systems.

\section{STIRRED-BED REACTORS}

Bench-scale studies were conducted to obtain design information on stirred-bed reactors. Excluding the startup period, four test reactors were satisfactorily operated for 428 days out of a total of 453 test days. The inlet feed concentration was a nominal $10 \mathrm{wt} \%$ nitrate, with a nominal 20-day residence time in the reactors. The effluent from the reactors contained less than $0.01 \mathrm{wt} \%$ nitrate, with the systems being operated at a reduction efficiency of greater than $99.9 \%$. The maximum denitrification rate was not established, but nominal rates of 10 grams of nitrate per day per cubic decimeter of reactor solution were typical. Plant design data showed that a $94.5-m^{3}(25,000$-qall) vessel, operating on the same nitrate leed, could be expected to decompose more than $181,500 \mathrm{kgs}(400,000 \mathrm{lbs})$ of nitrate per year. All bench-scale studies used calcium acetate as the carbon source. Also, the acidic wastes were not neutralized prior to adding them to the reactor. The excess calcium carbonate particles in the vessel served to neutralize the feed solution.

\section{PILOT-PLANT STUDIES}

The continuous-flow, stirred-bed reactor design was selected for scaleup studies because of the removal problems associated with the expected large volumes of calcium carbonate and aluminum hydroxide solids. A large vessel $\left(15 \mathrm{~m}^{3}\right)$ was modified and operated as a stirred-bed reactor. Test data showed the same denitrification rates (nominally, $10 \mathrm{~g}$ $\mathrm{NO}_{3}^{-} /$day/dm ${ }^{3}$ of solution) were obtained in the pilot-plant reactor as were obtained in the labnratory studies. The moximum rate uf denitriflcation was not determined in the pilot-plant tests. 
A test was made in the pilot-plant studies using a feed solution containing a mixture of methanol and calcium acetate. The results showed that the system did not operate satisfactorily, because the calcium acetate was utilized in preference to the methyl alcohol as an organic carbon source.

Engineering design data for a plant-sized denitrification stirred-bed reactor have been completed. 


\section{INTRODUCTION}

A development program has been completed at both the Oak Ridge National Laboratory and the Oak Ridge $Y-12$ Plant (a). to develop process design information for the installation of facilities to curtail or eliminate the indirect release of acidic nitrate effluents from a uranium purification process. Essentially all of the nitrate waste streams are generated by uranium solvent extraction recovery processes as acidic evaporator condensates and aluminum nitrate-containing extraction raffinates. Pilot-plant studies have been completed on conventional distillation and recycling of the nitric acid-water evaporator condensate streams and the raffinate streams containing aluminum nitrate, calcium nitrate, and extracted impurities. Most of the aluminum nitrate will be recycled by the evaporation and recrystallization operations. A waste stream from the evaporation/recrystallization process (or the "mother liquor") will require further treatment.

Since the mother-liquor stream could not be recycled to the plant, an acceptable disposal method was required. Several approaches to this problem were considered, but the most promising method appeared to be biological denitrification. The principle of biological denitrification has been studied by many investigators. In general, the nitrate concentration in the waste streams previously studied was in the order of several hundred parts per million. In the case of the mother-liquor streams, nitrate concentrations up to $40 \mathrm{wt} \%$ were typical. To obtain feasibility data on the denitrification process, a research study was conducted at the Oak Ridge National Laboratory. This study used nitrate wastes obtained from several uranium processing plants which contained calcium, sodium, and ammonium salts. The experiments were focussed on columnar denitrification systems, and the significant findings are recorded in this report.

The mother-liquor stream from the $\mathrm{Y}-12$ Plant contains high concentrations of aluminum and calcium salts which precipitate as hydroxides or carbonates during the biological denitrification process. These solids cause plugging of columnar reactors and, therefore, continuous-flow stirred-bed reactor studies were proposed and conducted. Laboratory and pilot-plant-sized equipment were operated to obtain the engineering design data.

(a) Both facilities are onerated by the Union Carbide Corpuraliun's Nuclear Division tor the US Energy Research and Development Administration. 


\section{ACID WASTE DENITRIFICATION}

\section{THEORY}

Biological denitrification is the reduction, by microorganisms, of nitrates or nitrites to gaseous molecular nitrogen or the oxides of nitrogen. "Dissimilatory biological denitrification" is nitrate reduction where the nitrate serves as the terminal electron (hydrogen) acceptor in the oxidation of an organic substrate by a large number of facultative anaerobic bacteria. This term should not be confused with "assimilatory denitrification", which is the reduction of nitrates or nitrites to ammonia for the synthesis of amino acids, amino sugars, and nucleotides in anabolic cell metabolism.

Biological denitrification can unly occur under an anaerobic cnvironment or at least a "reduced" environment where the redox potential is less than 2bu miv. Oprimumi denitrification occurs in the $\mathrm{pH}$ range from 7.5 to 8.5 . Two substrates must be available-nitrate and an energy source which is usually a hydrocarbon that also supplies carbon for additional cell synthesis.

\section{COLUMNAR DENITRIFICATION STUDIES}

\section{Description of the Unit}

A columnar denitrification unit is an enclosed reactor that contains submerged inert packing material which provides a large surface area for bacterial growth. The system is operated under flooded conditions with flow either upward or downward. Most columnar units are operated by directing the influent in an upward direction at a slow flow rate to promote separation of the microbial population from the effluent. A major portion of the microbial nnpulation is attached to the medium, but a small fraction is suspended in the effluent and consequently lost.

\section{Materials and Methods}

The packing medium used in this study included anthracite coal particles and polypropylene Raschig rings. Both are available commercially. The anthracite coal(b) has an effective particle diameter between 2 and $3 \mathrm{~mm}$. The particles dre angular and irrogularly shiuped aird have an average particle density of approximately $1.5 \mathrm{~g} / \mathrm{cm}^{3}$. Initial bed porosity after placement in the column was $36 \%$. The polypropylene Raschig rings $(\mathrm{c})$ are $1.6 \times 1.6 \mathrm{~cm}$ in diameter and have a geometric surface of $3.2 \mathrm{~m}^{2} / \mathrm{m}^{3}$ and a free space of $92 \%$.

All reactors were seeded from a microbial soil culture obtained in the following manner: Approximately $10 \mathrm{~g}$ of a soil from an organic horizon of an Emory slit, loam on

(b) Identified by the trade name, "Filt-O-Cite 1.5" and was obtained from the Shamoking Filter Co, Inc, Shamokin, Pennsylvania.

(c) Identified by the trade name, "Flexirings" and were obtained from Koch Engineering Co, Wichita, Kansas. 
ORNL property were added to $8 \mathrm{dm}^{3}$ of $\mathrm{Ca}\left(\mathrm{NO}_{3}\right)_{2}$ solution containing approximately 1000 $\mathrm{g} \mathrm{NO}_{3}-/ \mathrm{m}^{3}$ and $600 \mathrm{~g} \mathrm{CH}_{3} \mathrm{OH} / \mathrm{m}^{3}$. Anaerobic conditions and occasional stirring every three to four days produced a healthy culture of denitrifiers after 10 - 20 days. Columnar units were seeded by recycling $80 \mathrm{dm}^{3}$ of $\mathrm{Ca}\left(\mathrm{NO}_{3}\right)_{2}$ solution containing approximately $1000 \mathrm{~g}$ $\mathrm{NO}_{3}-/ \mathrm{m}^{3}, 600 \mathrm{~g} \mathrm{CH}_{3} \mathrm{OH} / \mathrm{m}^{3}$, and $2 .-3 \mathrm{dm}^{3}$ of an active culture of denitrifiers. Recycling continued until a microbial population was established on the packing medium; subsequently, nitrate feed containing $0.6 \mathrm{~g} \mathrm{CH}_{3} \mathrm{OH} / \mathrm{g} \mathrm{NO}_{3}^{-}$was passed slowly $(0.61$ to 2.9 $\mathrm{dm}^{3} / \mathrm{hr}$ ) through the column. Influent solutions were made with spring water; and, in addition to the nitrate and carbon substrate, contained the following chemicals in moles per liter: $\mathrm{KH}_{2} \mathrm{PO}_{4}, 3.2 \times 10^{-4}, \mathrm{MgSO}_{4}, 7.7 \times 10^{-4} ; \mathrm{FeCl}_{3} \cdot 6 \mathrm{H}_{2} \mathrm{O}, 2.75 \times 10^{-3}$, and $\mathrm{NaMoO}_{4} \cdot 2 \mathrm{H}_{2} \mathrm{O}, 4.13 \times 10^{-7}$.

Nitrate measurements were made with an Orion Nitrate Specific Electrode, Model 92-07, connected to a Corning, Model 110, digital, expanded-scale pH meter. Interferences by nitrite were eliminated by complexing the nitrite with sulfanilamide in $0.01 \mathrm{~N} \mathrm{H}_{2} \mathrm{SO}_{4}$ according to the procedure of Francis and Malone. (1) Use of the $\mathrm{H}_{2} \mathrm{SO}_{4}$ acts as an ionic strength adjustor and eliminates any interferences by $\mathrm{HCO}_{3}^{-}$and $\mathrm{CO}_{3}{ }^{-2}$. Nitrite concentrations were determined colorimetrically according to Bremner, (2) and $\mathrm{CH}_{3} \mathrm{OH}$ concentrations with a gas chromatograph.

Two columnar units were used: the first, a glass column ( 120 by $15 \mathrm{~cm}$ diameter) and the second, a tapered column made of Plexiglas.

\section{Method of Expressing Denitrification Rates}

Assuming that an adequate carbon source is available, the nitrate removal rate is dependent on nitrate concentration and microbial cell concentration. Anaerobic columnar units (cnnventionally called "pocked-bed reactors"), in which the intluent nitrate stream is introduced at the bottom of the column, encourage maximum microbial cell concentrations in denitrification reactors due to the large surface area provided by the packing matrix. As cell buildup in the column exceeds that washed from the reactor, the hydraulic residence time in the column decreases at constant influent flow rates. Continued cell buildup eventually plugs the column unless such preventive measures as backwashing or flushing are taken. As denitrification progresses, the void spaces become filled with $\mathrm{N}_{2}$ and $\mathrm{CO}_{2}$ rather than substrate. Thus, any hydraulic residence time based on the initial void space is a maximum value, and the real hydraulic residence times after prolonged operation of a column are likely to be lower by a factor of 5 to 10 . In this work, denitrification rates were not considered valid unless at least ten hydraulic residence times, based on the initial void space of the packing material, had elapsed. Valid denitrification rates in anaerobic columns should include current hydraulic residence times as well as microbial concentrations. This inclusion is made in the DENITRIFICATION KINETICS section; but, for the columnar studies, determinations of such parameters were considered impractical. For this reason, rates of denitrification are based on the initial volume of the packing medium in the following manner:

$$
R=24\left(\Delta \mathrm{NO}_{3}^{-}\right)(W) / V
$$


where:
$\mathrm{R}$ represents the denitrification rate, in $\mathrm{g} \mathrm{NO}_{3}-/$ day $/ \mathrm{dm}^{3}$,
$\triangle \mathrm{NO}_{3}{ }^{-}$the difference between the influent and effluent $\mathrm{NO}_{3}^{-}$concentration, in $\mathrm{kg} \mathrm{NO} 3^{-} / \mathrm{m}^{3}$,
W the flow rate, in $\mathrm{dm}^{3} / \mathrm{hr}$, and
$\checkmark \quad$ the initial volume of packing medium, in $\mathrm{dm}^{3}$.

\section{Results and Discussion}

Anthracite Loai PackIng - Glass Culuumiai Column - Solutions mado from three n!trate saitș $\left[\mathrm{Ca}\left(\mathrm{NO}_{3}^{-}\right)_{2}, \mathrm{NaNO}_{3}\right.$, and $\left.\mathrm{NH}_{4} \mathrm{NO}_{3}\right]$ and actual nitrate wastes from a $\mathrm{UO}_{2}$ fuel fabrication plant were used as influent solutions in the columnar denitrification studies. As reported earlier, (3) use of $\mathrm{Ca}\left(\mathrm{NO}_{3}\right)_{2}$ results in the formation of $\mathrm{CaCO}_{3}$, which causes high head losses $(>90 \mathrm{kPa})$ and eventually plugs the column. Calcium carbonate is the secondary reaction product formed from the calcium and $\mathrm{CO}_{2}$ that are produced by the denitrification reaction. Continuous-flow, stirred-bed reactors appear to be a more realistic engineering design to denitrify nitrate wastes where the dominant complemenlary cations are $\mathrm{Ca}^{+2}$ or $\mathrm{Al}^{+3}(4)$

With influent solutions made from $\mathrm{NaNO}_{3}$ or $\mathrm{NH}_{4} \mathrm{NO}_{3}$, no insoluble carbonate compounds are formen tn cause signifiçant head losses. However, effluent $\mathrm{pH}$ values are considerably higher when using $\mathrm{NaNO}_{3}$ and $\mathrm{NH}_{4} \mathrm{NO}_{3}$ rather than $\mathrm{Ca}\left(\mathrm{NO}_{3}\right)_{2}$, as noted in Table 1. The major difference in the denitrification of solutions containing $\mathrm{NaNO}_{3}$ and $\mathrm{NH}_{4} \mathrm{NO}_{3}$ is that rather high coricentrations of nitrite (as great as $1000 \mathrm{~g}$ $\mathrm{NO}_{2}^{-} / \mathrm{m}^{3}$ ) accumulate in the effluent of $\mathrm{NaNO}_{3}$ feed solutions, as the data of Table 2 points out. On the other hand, maximum concentrations of nitrite in the effluent of $\mathrm{NH}_{4} \mathrm{NO}_{3}$ solutions did not exceed

Table 1

INFLUENT AND EFFLUENT PH VALUES IN THE COLUMNAR DENITRIFICATION OF VARIOUS NITRATE FORMS (Anthracite Coul is the Packing Medium)

\begin{tabular}{|c|c|c|c|}
\hline \multirow[b]{2}{*}{ Nitrate Source } & \multicolumn{2}{|c|}{$\mathrm{pH}$ Value } & \multirow{2}{*}{$\begin{array}{l}\text { Number of } \\
\text { Observations }\end{array}$} \\
\hline & Influent & Effluent & \\
\hline $\mathrm{Ca}\left(\mathrm{NO}_{3}\right)_{2}$ & $7.15 \pm 0.09(1)$ & $7.62 \pm 0.21$ & 8 \\
\hline $\mathrm{NaNO}_{3}$ & $7.46 \pm 0.75$ & $8.55 \pm 0.76$ & 20 \\
\hline $\mathrm{NH}_{4} \mathrm{NO}_{3}$ & $6.86 \pm 0.09$ & $8.25 \pm 0.16$ & 13 \\
\hline $\mathrm{UO}_{2}$ Nitiate Wastes & $6.93 \pm 0.13$ & $8.23+0.1 .3$ & 10 \\
\hline
\end{tabular}

(1) Standard deviation. $10 \mathrm{~g} \mathrm{NO}_{2}-1 \mathrm{~m}^{3}$ at any time during the study. A similar observation was made in the stirred-bed reactor work. The addition of a small amount of arrimonium $\left(10-15 \mathrm{~g} / \mathrm{m}^{3}\right)$ to the $\mathrm{NaNO}_{3}$ influent solutions did not lower the nitrite accumulation, indicating that the accurrulation of nitrite is due to the levels of sodium rather than any possible ammonium nutrient deficiencies.

Denitrification rates with solutions containing $\mathrm{NH}_{4} \mathrm{NO}_{3}$ appear to be greater than those containing $\mathrm{NaNO}_{3}$ (Table 2). For example, the average denitrification rate with influent solutions containing $\mathrm{NaNO}_{3}$ was $21.2 \pm 13 \mathrm{~g} \mathrm{NO}_{3}^{-} /$day/dm 3 , while influents containing $\mathrm{NH}_{4} \mathrm{NO}_{3}$ averaged $28.6 \pm 12.9 \mathrm{~g} \mathrm{NO}_{3}^{-} /$day $/ \mathrm{dm}^{3}$, an approximate $35 \%$ increase. This 
difference indicates that denitrification of influent solutions containing $\mathrm{NH}_{4} \mathrm{NO}_{3}$ may be noticeably faster than for solutions containing $\mathrm{NaNO}_{3}$. However, this interpretation will be misleading if denitrification proceeds according to first-order kinetics, because the average concentration of nitrate in the $\mathrm{NH}_{4} \mathrm{NO}_{3}$ influents $\left(11.8 \mathrm{~kg} \mathrm{NO} 3^{-} / \mathrm{m}^{3}\right)$ was nearly twice the average nitrate concentration in the $\mathrm{NaNO}_{3}$ influents $\left(6.5 \mathrm{~kg} \mathrm{NO}{ }_{3}^{-} / \mathrm{m}^{3}\right)$. In addition, influents containing $\mathrm{NH}_{4} \mathrm{NO}_{3}$ followed those containing $\mathrm{NaNO}_{3}$, which introduces the possibility that a higher microbial population was present in the column for the $\mathrm{NH}_{4} \mathrm{NO}_{3}$ data.

Table 2

DENITRIFICATION IN AN ANTHRACITE COAL PACKING

\begin{tabular}{|c|c|c|c|c|c|}
\hline $\begin{array}{l}\text { Test } \\
\text { Date } \\
\text { (day) } \\
\end{array}$ & \multicolumn{2}{|c|}{ Nitrate Concentration $\left(\mathrm{kg} / \mathrm{m}^{3}\right)$} & $\begin{array}{l}\text { Flow Rate } \\
\left(\mathrm{cm}^{3} / \mathrm{hr}\right)\end{array}$ & $\begin{array}{c}\text { Nitrite Concentration } \\
\text { in Effluent } \\
\left(\mathrm{g} / \mathrm{m}^{3}\right) \\
\end{array}$ & \multirow[t]{2}{*}{$\begin{array}{c}\begin{array}{c}\text { Denitrification } \\
\text { Rate }(1)\end{array} \\
\left(\mathrm{g} \mathrm{NO}_{3}-/ \text { day } / \mathrm{dm}^{3}\right) \\
\end{array}$} \\
\hline & & & \multicolumn{2}{|c|}{ Influent Containing $\mathrm{NaNO}_{3}$} & \\
\hline 1 & 4.43 & 1.15 & 3.1 & 970 & 13 \\
\hline 2 & 5.76 & 2.30 & 3.3 & 1200 & 14 \\
\hline 4 & 4.52 & 0.62 & 1.7 & 1020 & 9.2 \\
\hline 5 & 5.54 & 1.28 & 0.83 & 164 & 9.2 \\
\hline 8 & 8.19 & 1.42 & 3.1 & 1050 & 3.5 \\
\hline 9 & 8.86 & 4.87 & 3.2 & 624 & 22 \\
\hline 10 & 8.64 & 4.87 & 3.1 & 230 & 23 \\
\hline 11 & 8.86 & 4.65 & 3.4 & 360 & 27 \\
\hline 14 & 3.10 & $<0.05$ & 2.5 & 0.7 & \\
\hline 15 & 3.94 & 0.50 & 4.1 & 624 & 23 \\
\hline 16 & 3.80 & 0.17 & 3.6 & 206 & 25 \\
\hline 17 & 1.24 & $<0.05$ & 3.4 & $<33$ & \\
\hline 18 & 4.87 & 0.06 & 3.6 & 181 & 35 \\
\hline 19 & 10.6 & 2.67 & 3.7 & 1250 & 51 \\
\hline
\end{tabular}

Influent Containing $\mathrm{NH}_{4} \mathrm{NO}_{3}$

$\begin{array}{lcrrrr}20 & 3.76 & <0.05 & 3.9 & <0.7 & 64 \\ 21 & 9.57 & 1.64 & 3.8 & <0.7 & 50 \\ 22 & 13.7 & 4.43 & 2.5 & 9.2 & 38 \\ 23 & 13.7 & 4.21 & 1.9 & <2.0 & 23 \\ 24 & 9.74 & 3.76 & 1.8 & 3.9 & 33 \\ 25 & 11.1 & 5.98 & 3.0 & - & 24 \\ 26 & 11.1 & 7.53 & 3.1 & - & 29 \\ 27 & 11.3 & 6.86 & 3.0 & 3.5 & 22 \\ 28 & 11.3 & 7.75 & 2.9 & 3.3 & 20 \\ 29 & 11.1 & 7.97 & 3.0 & 4.6 & 31 \\ 30 & 11.5 & 7.97 & 3.0 & 2.3 & 15 \\ 31 & 11.1 & 8.86 & 3.3 & 4.9 & 28 \\ 32 & 12.4 & 7.97 & 2.9 & 4.3 & 20 \\ 33 & 11.1 & 7.97 & 2.9 & 4.6 & 22 \\ 34 & 12.4 & 8.86 & 2.9 & - & 11 \\ 35 & 12.4 & 10.6 & 2.8 & 3.9 & 22 \\ 36 & 12.0 & 8.41 & 2.9 & - & 34 \\ 37 & 15.1 & 9.52 & 2.8 & & \end{array}$

(1) Denitrification rate based on the initial volume of the parking merdium $\left(11.12 \mathrm{dm}^{3}\right)$ in a $120 x$ 15 -cm-diarreter glass column. For influents containing $\mathrm{NaNO}_{3}$, rates were corrected for $\mathrm{NO}_{2}{ }^{-}$ accumulation. 
Anthracite Coal Packing - Tapered Plexiglas Column - Columns packed with anthracite coal appear to be a highly effective method for denitrifying high nitrate wastes. However, in the 120 -c.m-long by $15-\mathrm{cm}$-diameter column, flotation of the bed occurred at flow rates that exceeded $2.9 \mathrm{dm}^{3} / \mathrm{hr}$. Continued operation resulted in compaction of the bed against the top of the column which caused high head losses $(>50 \mathrm{kPa}$ ). Floating of the anthracite bed was caused by the low density $\left(1.5 \mathrm{~g} / \mathrm{cm}^{3}\right)$ of the anthracite particles, large microbial growth on the coal surfaces, and high production of nitrogen gas. Use of the same anthracite coal in a tapered column alleviated compaction of the bed at the top of the column, even at flow rates of $18 \mathrm{dm} 3 / \mathrm{hr}$; and, under optimum operating conditions, took on many properties of a fluidized bed.

Denitrification kinetics (discussed later) indicated that rates of denitrification became nitrate-substrate inhibited at nitrate concentrations greater than $6.0 \mathrm{~kg} \mathrm{NO} \mathrm{NO}_{3} / \mathrm{ml}^{3}$. Thus, greater denitrification should be obtained in lapered columns than in conventional columns because greater quantities of nitrate can be delivered to the unit at influent nitrate concentrations which do not inhibit denitrification; viz, a greater fruction of the microbial enzyme can be maintained in the active form at influent concentrations of $5 \mathrm{~kg} \mathrm{NO} 3_{3}^{-} / \mathrm{m}^{3}$ and at a flow rate of $18 \mathrm{dm} 3 / \mathrm{hr}$ than at an influent concentration of $31 \mathrm{~kg} \mathrm{NO}_{3}^{-} / \mathrm{m}^{3}$ at 3 $d m^{3} / h r$.

The column made of Plexiglas and tapered 0.23 rad deg outwardly (Figure 1) was filled with $32.5 \mathrm{dm}^{3}$ of the same anthracite coal used in the previously described columnar studies. The column was seeded with an active denitrifying culture in the manner previously described,

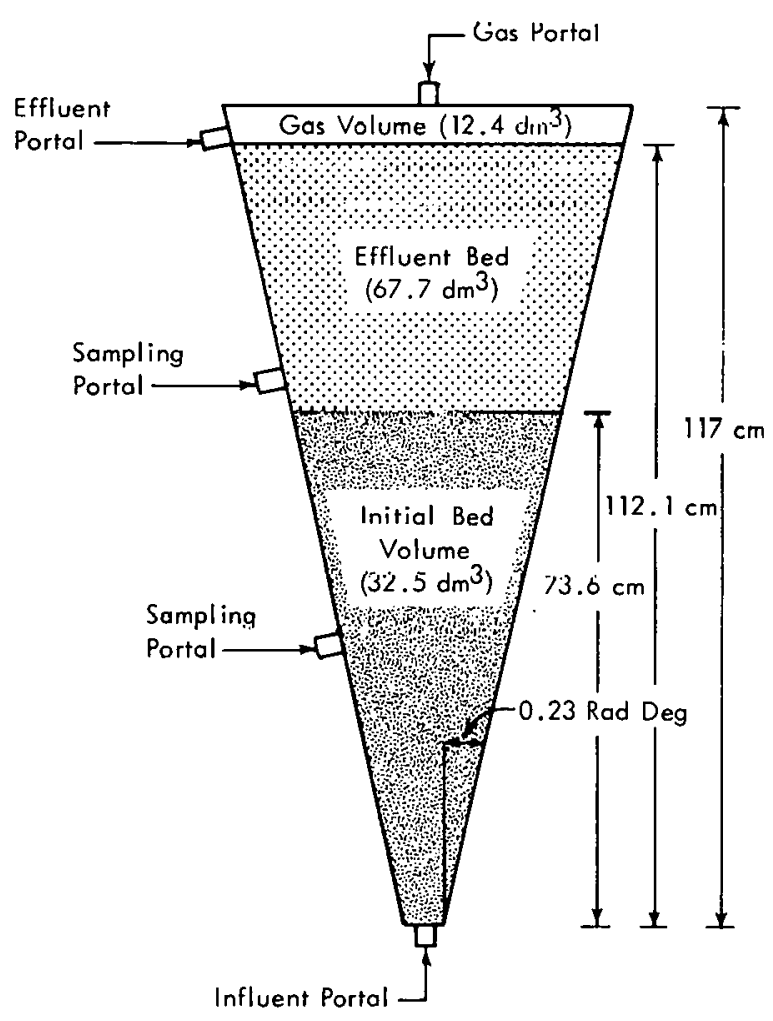

Figure 1. DESIGN OF THE TAPERED COLUMN. and an influent of $\mathrm{NH}_{4} \mathrm{NO}_{3}$ containing approximately $1 \mathrm{~kg} \mathrm{NO} 3^{-} / \mathrm{m}^{3}$ with $0.6 \mathrm{~kg}$ $\mathrm{CH}_{3} \mathrm{OH} / \mathrm{m}^{3}$ was fed to the unit for three weeks before the denitrification data presented in Figure 2 and Table 3 were collected. Visual observations revealed that the microbial growth was predominantly located in the lower one third of the column, indicating that an equilibrium microbial biomass had not been attained over the entire bed. Yet, the denitrification rate of $44 \mathrm{~g} \mathrm{NO}_{3}^{-} /$day $/ \mathrm{dm}^{3}$ observed the first day of measurement (Table 3) was considerably higher than the average observed rate $\left(29 \mathrm{~g} \mathrm{NO}_{3}\right.$ / /day/dm 3 ) obtained with $\mathrm{NH}_{4} \mathrm{NO}_{3}$ in the $120-\mathrm{cm} \cdot$ long by 15-cm-diameter column.

Denitrification performance in the tapered colurm over a 41-day interval is reporled in Figure 2. On the fitth day, an influent containing $11.1 \mathrm{~kg} \mathrm{NO} 3^{-} / \mathrm{m}^{3}$ as $\mathrm{NH}_{4} \mathrm{NO}_{3}$ and acetic acid (neutralized with $\mathrm{NaOH}$ ) (equivalent in terms of carbon to $0.6 \mathrm{~g}$ $\mathrm{CH}_{3} \mathrm{OH} / \mathrm{g} \mathrm{NO}_{3}^{-}$) was fed to the unit at 
$13.4 \mathrm{dm}^{3} / \mathrm{hr}$ (influent $\mathrm{pH}$ was 7.35). The following day, nitrate analyses of the influent and effluent, and the observation that there was no difference between the temperature of the two streams, indicated that denitrification had ceased.

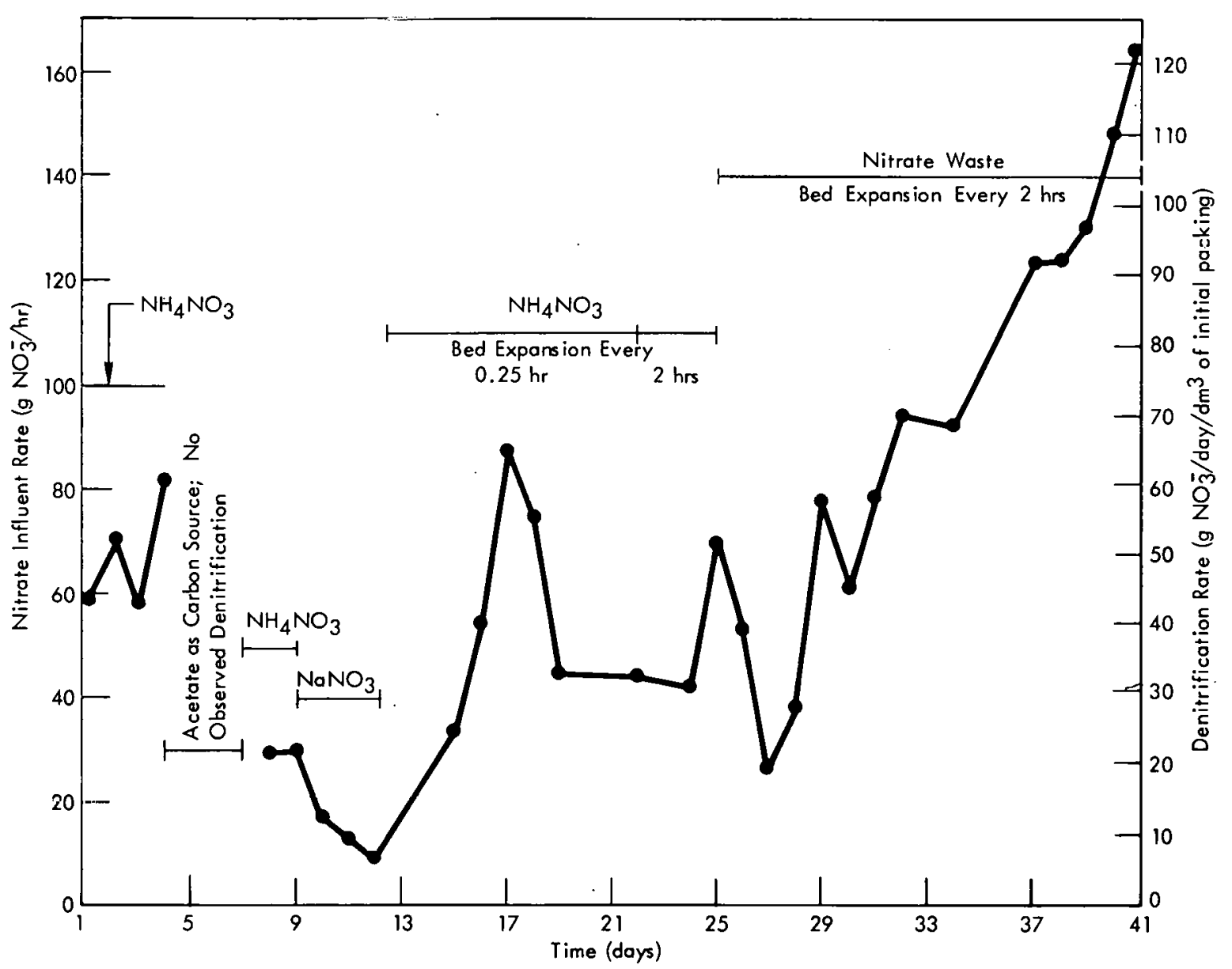

Figure 2. INFLUENCE OF NITRATE AND CARBON SOURCE, BED EXPANSION, AND TIME ON DENITRIFICATION IN A TAPERED COLUMN.

To avoid loss of the established microbial population, methanol was substituted for sodium acetate as the carbon substrate. Nitrate analyses on the eighth and ninth day verified that denitrification had resumed but at a much lower rate. However, the high influent nitrate concentrations may have been partially responsible for the low rates. Switching to $\mathrm{NaNO}_{3}$ as a nitrate source reduced the denitrification $75 \%$ afler three days. The reduction was due either to continued exposure to nitrate concentrations greater than $15.0 \mathrm{~kg} \mathrm{NO} 3^{-} / \mathrm{m}^{3}$ or to some spccific effect associated with $\mathrm{NaNO}_{3}$.

Taking into consideration the large quantities of nitrate detected in the $\mathrm{NaNO}_{3}$ effluents from the 120 by $15-\mathrm{cm}$ columns, reduction in the denitrification rate was likely due to the inability of the microorganisms to acclimatize quickly to $\mathrm{NaNO}_{3}$. For example, a similar, but not as severe, reduction in denitrification was noted on the substitution of $\cup_{2}$ fuel nitrate wastes (predominantly $\mathrm{NH}_{4} \mathrm{NO}_{3}$ and $\mathrm{HNO}_{3}$ neutralized to a $\mathrm{pH}$ of 6.4 ) for $\mathrm{NH}_{4} \mathrm{NO}_{3}$ on the 26th and 27 th day. The difference between these nitrate sources was rather subtle; 
ie, the ratio of nitrate to ammonium, on a weight basis, in the $\mathrm{UO}_{2}$ nitrate wastes was 5 to 1 rather than 3.5 to 1 as in $\mathrm{NH}_{4} \mathrm{NO}_{3}$, and the influent concentration of calcium after dilution with spring water was about $600 \mathrm{~g} / \mathrm{m}^{3} \mathrm{com}$ pared to less than $20 \mathrm{~g} / \mathrm{m}^{3}$ for $\mathrm{NH}_{4} \mathrm{NO}_{3}$ influent. Even so, acclimatization for approximately three days was required beforc similar denitrification rates were attained.

I hrough the Plexiglas walls of lie column, it couldbe seen that a large number of pores in the anthracite bed were filled with gas rather than nitrate solution, indicating that the packing material was not being utilized efficiently. On the 15th day, to maximize bed efficiency, the bed was expanded by pumping (for 30 s) approximately $5 \mathrm{dm}^{3}$ (flow rate of 600 $\mathrm{dm}^{3} / \mathrm{hr}$ ) of effluent from a sump every $0.25 \mathrm{hr}$. The manner in which this pumping was conducted is illustrated in Figure 3. This procedure agitated the packing medium so that the gaseous denitrification products were discharged, thus increasing the hydraulic residence time of Tresti influent into the column. Bed expansion in this fashion was carried out every $0.25 \mathrm{hr}$ until the 22rid day when visual observations and a sharp decline in the rate of denitrification indicated that microorganisms were being washed from the column faster than they were being produced. On the 23rd day, bed expansion was changed to every 2 hrs. Gaseous discharge during bed expansion was quite high (as great as $2 \mathrm{dm}^{3}$, or approximately $240 \mathrm{dm}^{3} / \mathrm{hr}$ ).
Table 3

DENITRIFICATION IN THE TAPERED COLUMN PACKED WITH ANTHRACITE COAL

\begin{tabular}{|c|c|c|c|c|}
\hline \multirow{2}{*}{$\begin{array}{l}\text { Test } \\
\text { Date } \\
\text { (day) }\end{array}$} & \multicolumn{2}{|c|}{$\begin{array}{c}\text { Nitrate Concentration } \\
\left(\mathrm{kg} / \mathrm{m}^{3}\right)\end{array}$} & \multirow{2}{*}{$\begin{array}{c}\text { Flow Rate } \\
\left(\mathrm{cm}^{3} / \mathrm{hr}\right)\end{array}$} & \multirow{2}{*}{ 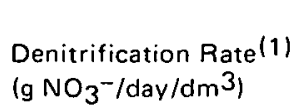 } \\
\hline & Influent & Effluent & & \\
\hline & . & \multicolumn{2}{|c|}{ Influcnt Containing $\mathrm{NH}_{4} \mathrm{NO}$} & \\
\hline 1 & 4.87 & 0.36 & 13.2 & 44 \\
\hline 2 & 7.53 & 2.21 & 13.2 & 52 \\
\hline 3 & 8.86 & 5.09 & 17.3 & 43 \\
\hline 4 & 12.8 & 7.31 & 14.8 & 60 \\
\hline
\end{tabular}

Actate Usced dis Cull buil Suurco

$\begin{array}{llll}22.1 & 15.5 & 4.4 & 22\end{array}$

$\begin{array}{llll}22.1 & 15.5 & 4.5 & 22\end{array}$

Influent Containing $\mathrm{NaNO}_{3}$

$\begin{array}{lllll}10 & 23.0 & 19.5 & 4.8 & 12 \\ 11 & 20.4 & 17.7 & 4.8 & 9.5 \\ 12 & 17.7 & 15.9 & 4.8 & 6.0\end{array}$

Influent Containing $\mathrm{NH}_{4} \mathrm{NO}_{3}$

With Bed Expansion Every $0.25 \mathrm{Hr}$

$\begin{array}{lclll}15 & 7.31 & 3.19 & 8.1 & 24 \\ 16 & 7.75 & 1.02 & 8.1 & 40 \\ 17 & 12.0 & 0.55 & 7.7 & 65 \\ 18 & 15.5 & 7.75 & 9.6 & 55 \\ 19 & 12.8 & 8.19 & 9.6 & 33\end{array}$

With Bod Expansion Every 2 Hrs

$\begin{array}{lcccc}22 & 10.2 & 4.21 & 7.4 & 33 \\ 24 & 7.53 & 2.66 & 8.7 & 31 \\ 25 & 15.5 & 2.97 & 5.6 & 52\end{array}$

$\mathrm{UO}_{2}$ Fuel Nitrate Waste

With Bed Expansion Every $2 \mathrm{Hrs}$

$\begin{array}{rcccc}26 & 11.1 & 2.57 & 6.3 & 40 \\ 27 & 7.97 & 5.31 & 9.9 & 19 \\ 28 & 10.1 & 3.10 & 5.3 & 28 \\ 29 & 12.8 & 3.10 & 8.0 & 58 \\ 30 & 12.2 & 5.53 & 9.2 & 45 \\ 31 & 13.7 & 5.31 & 9.4 & 58 \\ 32 & 13.3 & 3.10 & 9.2 & 69 \\ 34 & 22.1 & 11.9 & 9.1 & 68 \\ 37 & 15.9 & 8.6 & 16.8 & 91 \\ 38 & 11.5 & 4.43 & 17.5 & 92 \\ 39 & 12.4 & 4.43 & 16.4 & 96 \\ 40 & 12.4 & 3.81 & 16.1 & 102 \\ 41 & 15.5 & 5.31 & 16.2 & 122\end{array}$

(1) Denitrification rate based on the initial volume of packing medium (32.5 dm 3 ). Nitrite measurements were not routinely made; however, random effluent samples of $\mathrm{NH}_{4} \mathrm{NO}_{3}$ and $\mathrm{UO}_{2}$ fuel nitrate wastes did not reveal any concentrations greater than $10 \mathrm{~g} \mathrm{NO}_{2}-/ \mathrm{m}^{3}$. 


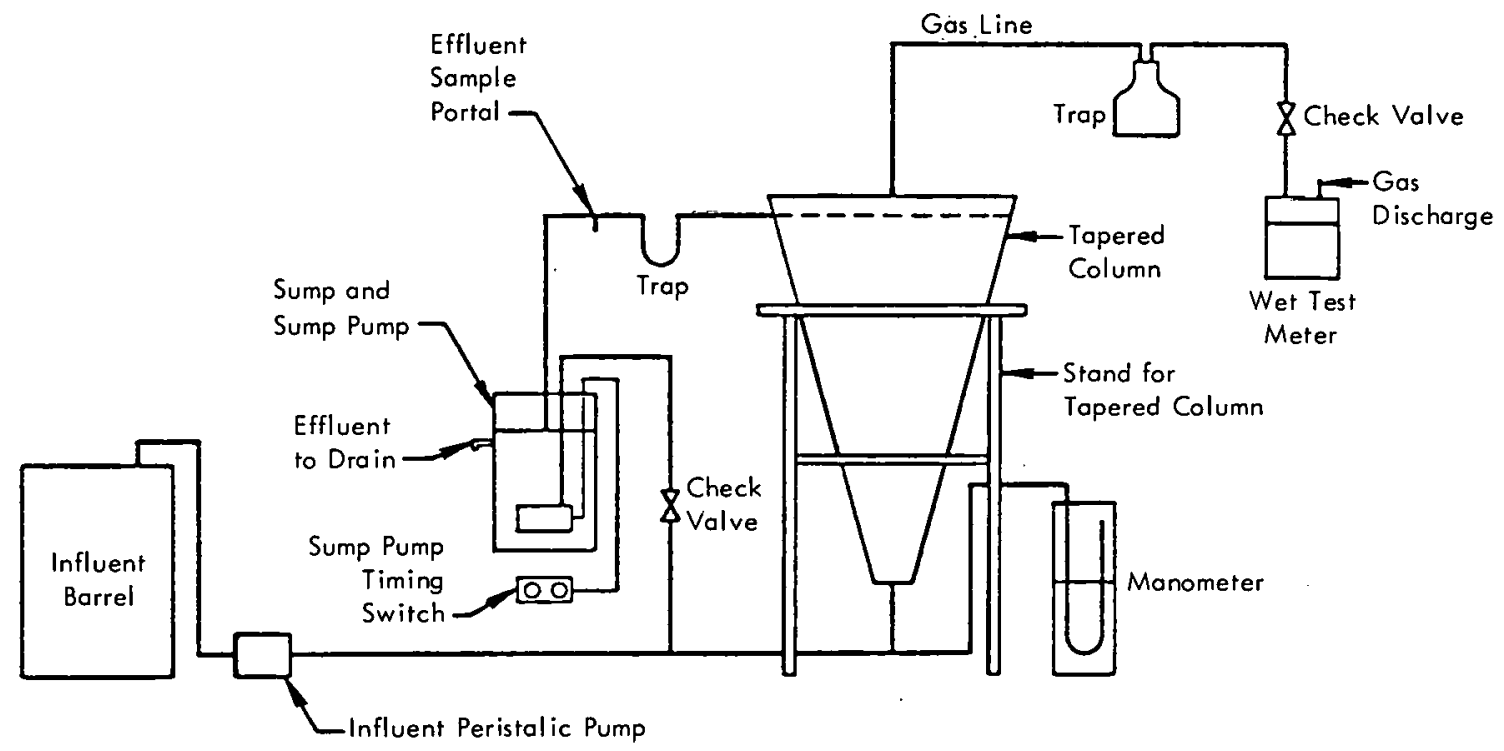

Figure 3. PRINCIPAL COMPONENTS OF THE TAPERED.COLUMN DENITRIFICATION SYSTEM.

At the termination of the experiment, denitrification rates were established in excess of 100 $\mathrm{g} \mathrm{NO}_{3}-/ \mathrm{day} / \mathrm{dm}^{3}$ (Table 3). These rates are 10-15 times higher than those reported in continuous-flow, stirred-bed reactors. $(4)$

Gaseous Discharge - The primary gaseous products of denitrification are elemental nitrogen and carbon dioxide:

$$
5 \mathrm{CH}_{3} \mathrm{OH}+6 \mathrm{NO}_{3}^{-} \rightarrow 5 \mathrm{CO}_{2}+3 \mathrm{~N}_{2}+7 \mathrm{H}_{2} \mathrm{O}+6 \mathrm{OH}^{-}
$$

The gaseous dischlarye from the tapered column packed with anthracite coal and fed with $\mathrm{UO}_{2}$ fuel fabrication wastes was approximately $92 \% \mathrm{~N}_{2}$ and $8 \% \mathrm{CO}_{2}$ (Table 4). Considering the stoichiometric ratio of $\mathrm{CO}_{2}$ to $\mathrm{N}_{2}$ from the equation, the concentration of $\mathrm{CO}_{2}$ in the gaseous discharge was extremely low. However, the $\mathrm{pH}$ of the effluent was approximately 8.2 (Table 1); therefore, the bulk of the carbon leaves lhe reactor in the form of $\mathrm{HCO}_{3}{ }^{-}$and $\mathrm{CO}_{3}-2$. Surne carbon left the reactor in the form of microbial solids. Values for mixed liquor volatile suspended solids (MLVSS) in the effluents ranged from 100 to $900 \mathrm{~g} / \mathrm{m}^{3}$. Carbon was also retained inside the reactor as carbonates and microbial carbon.

\section{Calcium and Phosphorus Retention -}

When anthracite coal is used as the packing medium, $99 \%$ of the calcium is removed from influent streams that contain less than $1000 \mathrm{~g} / \mathrm{m}^{3}$ calcium (Table 5). X-ray diffraction patterns of suspended solids in stirred reactors show

Table 4

DENITRIFICATION GAS ANALYSES FROM THE TAPERED COLUMN PACKED WITH ANTHRACITE COAL

\begin{tabular}{ccclllll}
\hline & \multicolumn{7}{c}{ Gas (\% by volume) } \\
\cline { 2 - 7 } Sample & $\mathrm{N}_{2}$ & $\mathrm{CO}_{2}$ & \multicolumn{1}{c}{$\mathrm{O}_{2}$} & \multicolumn{1}{c}{$\mathrm{NO}$} & \multicolumn{1}{c}{$\mathrm{Ar}$} & $\mathrm{CH}_{3} \mathrm{OH}$ \\
\hline 1 & 95.42 & 4.54 & 0.008 & 0.01 & 0.03 & 0.002 \\
2 & 90.36 & 9.42 & 0.0084 & 0.02 & 0.06 & 0.09 \\
3 & 90.63 & 9.01 & 0.02 & 0.09 & 0.008 & 0.15 \\
4 & 92.39 & 7.40 & 0.07 & 0.008 & 0.02 & 0.06 \\
5 & 92.24 & 7.58 & 0.03 & 0.02 & 0.007 & 0.05 \\
Average & 92.21 & 7.59 & 0.027 & 0.03 & 0.025 & 0.07 \\
Standard & 2.02 & 1.92 & 0.026 & 0.03 & 0.021 & 0.05 \\
Deviation & & & & & & \\
\hline
\end{tabular}


that calcium is precipitated as $\mathrm{CaCO}_{3}$. The same is likely to hold true for columnar denitrification. Elements other than calcium were also removed; for example, phosphorus, for which the mechanisms responsible remain unclear. $X$-ray patterns characteristic of any calcium phosphates were not detected. in the suspended solids from the stirred reactors. Quite likely, a relationship exists similar to that of phosphorus adsorption in alkaline soils; ie, phosphorus is either coprecipitated with or strongly occluded to $\mathrm{CaCO}_{3}$.

Table 5

ELEMENT REMOVAL DURING DENITRIFICATION IN A TAPERED COLUMN PACKED WITH ANTHRACITE COAL

\begin{tabular}{lccc}
\hline \multirow{2}{*}{ Eleritent } & \multicolumn{2}{c}{$\begin{array}{c}\text { Elcment Concentration } \\
\left(\mathrm{g} / \mathrm{m}^{3}\right)\end{array}$} & $\begin{array}{c}\text { Extent of } \\
\text { Hemovai } \\
(\%)\end{array}$ \\
\cline { 2 - 2 } Calcium & 645 & 7.0 & 99 \\
& 792 & 4.6 & 99 \\
& 615 & 5.7 & 99 \\
Influcnt & Effluent & \\
Phosphiurus & 3.0 & 1.3 & 57 \\
& 5.1 & 0.52 & 90 \\
Zinc & 7.1 & 1.2 & 83 \\
Nickel & 0.15 & $<0.005$ & $>96$ \\
Copper & 0.30 & $<0.1$ & $>66$ \\
Cadmium & 0.20 & 0.035 & 82 \\
& 0.06 & $<0.005$ & $>91$ \\
\hline
\end{tabular}

Trace-Element Retention - Reaction mechanisms governing the removal of the transition metals ( $\mathrm{Zn}, \mathrm{Ni}$, and $\mathrm{Cu}$ ) are urikruwiı. Fiolonged use of an anthracite bed for denitrification of influent streams containing appreciable quantities of these heavy metals will result in the accumulation of rather large quantities of these metals. It is also difficult to predict what effect the buildup of the metals will have on subsequent denitrification. Further research in this area is required. Cadmium likely behaves like calcium because its ionic radius is nearly equal to that of calcium. Cadmium probably precipitates as $\mathrm{CdCO}_{3}$. or in mixtures of $\mathrm{CdCO}_{3} \cdot \mathrm{CaCO}_{3}$.

Denitrification columns packed with anthracite coal might be useful in uranium recovery operations. For example, $\mathrm{NH}_{4} \mathrm{NU}_{3}$ solution contalning $5-10 \mathrm{y} / 111^{3}$ of uranium was lowerod to less than $0.5 \mathrm{~g} / \mathrm{m}^{3}$ in one pass through a column packed with $11.12 \mathrm{dm}^{3}$ of anthracite coal. The uranium likely coprecipitated un the calcium and magncsium carbonates, or is converted to an insoluble phosphate mineral similar to that of apatite, which is known to selectively concentrate uranium. The chemistry of thorium and plutonium indicates that these elements would behave in a similar manner. Thus, columns of this type may be useful in removing low levels of plutonlum frum wasle streams containing nitratus.

Influence of Temperature-Denitrification is an exothermic reaction. The difference between the influent and effluent temperatures on the 3yth day was 12 degrees (295 vs 307 $\mathrm{K})$. At a tlow rate of $4.55 \mathrm{~cm}^{3} / \mathrm{s}$, and assuming a vater density of $1 \mathrm{~kg} / \mathrm{m}^{3}$ with is ipecilic heat of $4.48 \mathrm{~J} / \mathrm{g} / \mathrm{K}$, the rate of energy required to raise the influent to $30 \% \mathrm{~K}$ would be 228 $\mathrm{J} / \mathrm{s}$. Presumably, this heat is generated by the oxidation of $\mathrm{CH}_{3} \mathrm{OH}$. The quantity of heat generated by the oxidation of $\mathrm{CH}_{3} \mathrm{OH}$ can be calculated in the following manner: The observed denitrification rate was $36.3 \mathrm{mg} \mathrm{NO} 3^{-} / \mathrm{s}$. Methanol analysis of the influent and effluent showed that $0.52 \mathrm{~g}$ of $\mathrm{CH}_{3} \mathrm{OH}$ was required to denitrify a gram of nitrate. Thus, the oxidation rate of $\mathrm{CH}_{3} \mathrm{OH}$ was $18.9 \mathrm{mg} \mathrm{CH} 3 \mathrm{OH} / \mathrm{s}$. If the heat of combustion for $\mathrm{CH}_{3} \mathrm{OH}$ is taken as $0.71 \mathrm{MJ} / \mathrm{mol}$, then the rate of energy released on oxidizing is $422 \mathrm{~J} / \mathrm{s}$. Thus, the rate of heat generated is nearly twice that reflected by the increase in influent temperature. A portion of the remaining energy is used for microbial growth while the remainder is lost as heat to the surrounding environment. 
A large unit, one capable of denitrifying five metric tons of nitrate daily and operating at this efficiency, will generate considerable energy (58.1 GJ/day), which is equivalent to 54.6 $\times 10^{6} \mathrm{Btu} /$ day. Quite likely the heat loss in a larger unit will be much less, which means that the heat generated may limit (up to a certain temperature may increase) the rate of denitrification. It appears that some type of cooling of larger units will be necessary if they are to operate at maximum efficiency.

\section{Polypropylene Raschig Rings}

Microbial populations were established faster on polypropylene Raschig rings than on the anthracite coal packing ( $v i z,<2$ weeks on rings compared to $3-4$ weeks on the coal). Maximum denitrification rates (Table 6), based on the initial bed size, were similar $(100 \mathrm{~g}$ $\mathrm{NO}_{3}{ }^{-} /$day/dm 3 ). However, on prolonged operation $(>40$ days), denitrification rates began to decrease to $20-30 \mathrm{~g} \mathrm{NO}_{3}^{-} /$day/dm 3 after $50-60$ days (Table 6 ). This reduction in denitrification rates was attributed to hydraulic short circuiting in the column due to excessive microbial growth.

For instance, after 30-35 days, areas of dark-colored microorganisms were observed in the lower portion of the column. Healthy denitrifiers are pink colored, and they rapidly turn black if they do not receive a sufficient supply of nitrate. Initially, the darkcolored organisms were suspected of being sulfate-reducing microorganisms even though no evidence of $\mathrm{H}_{2} \mathrm{~S}$ could be detected. Sulfate concentration in the influent was reduced by a factor of 10 , but the dark-colored areas continued to grow. On the 45th day, the column was flushed for $0.33 \mathrm{hr}$ at a flow rate of $414 \mathrm{dm}^{3} / \mathrm{hr}$. Visual observation of the effluent or micrnhial mass in the column indicated that little biomass had been removed, and dcnitrification rates the following 10 days were not appreciably changed. At the end of the experiment, mixed liquor suspended solids (MLSS) were $28.7,37.6$, and $83.0 \mathrm{~kg} / \mathrm{m}^{3}$ at the top, center, and bottom

Table 6

DENITRIFICATION IN A COLUMN PACKED WITH POLYPROPYLENE RASCHIG RINGS

\begin{tabular}{|c|c|c|c|c|}
\hline \multirow{2}{*}{$\begin{array}{l}\text { Test } \\
\text { Time } \\
\text { (day) }\end{array}$} & \multicolumn{2}{|c|}{$\begin{array}{c}\text { Nitrate Concentration } \\
\left(\mathrm{kg} / \mathrm{m}^{3}\right)\end{array}$} & \multirow{2}{*}{$\begin{array}{l}\text { Flow Rate } \\
\left(\mathrm{cm}^{3} / \mathrm{hr}\right)\end{array}$} & \multirow{2}{*}{$\begin{array}{c}\text { Denitrification } \\
\text { Rate }(1) \\
\text { (g NO} 3 \text {-/day } / \mathrm{dm}^{3} \text { ) }\end{array}$} \\
\hline & Influent & Effluent & & \\
\hline 10 & 2.43 & 0.71 & 2.6 & 4.7 \\
\hline 11 & 2.21 & 1.20 & 0.9 & 0.95 \\
\hline 12 & 2.21 & 1.33 & 2.6 & 2.4 \\
\hline 13 & 2.08 & 0.95 & 2.0 & 2.3 \\
\hline 14 & 3.10 & 1.20 & 2.9 & 5.6 \\
\hline 15 & 2.21 & 0.93 & 2.0 & 3.9 \\
\hline 16 & 2.74 & 0.75 & 3.0 & 6.1 \\
\hline 17 & 2.30 & 0.55 & 3.6 & 6.6 \\
\hline 18 & 2.26 & 0.06 & 2.7 & 6.0 \\
\hline 19 & 2.21 & $<0.05$ & 3.7 & $>8.4$ \\
\hline 20 & 2.61 & $<0.05$ & 6.7 & $>18$ \\
\hline 22 & 2.26 & $<U .05$ & 9.8 & $>22$ \\
\hline 23 & 3.19 & $<0.05$ & 19.3 & $>64$ \\
\hline 24 & 3.10 & 0.82 & 19.1 & 44 \\
\hline 25 & 3.45 & 0.66 & 18.8 & 54 \\
\hline 27 & 2.66 & $<0.05$ & 18.7 & $>50$ \\
\hline 31 & 2.83 & 0.56 & 18.5 & 43 \\
\hline 36 & 4.87 & $<0.05$ & 17.2 & $>86$ \\
\hline 37 & 5.09 & 0.16 & 21.3 & 108 \\
\hline 38 & 5.31 & 0.93 & 19.2 & 86 \\
\hline 41 & 4.98 & 0.80 & 18.6 & 80 \\
\hline 42 & 4.65 & 0.83 & 18.7 & 74 \\
\hline 43 & 5.53 & 0.74 & 18.6 & 32 \\
\hline 45 & 4.03 & 1.90 & 18.8 & 41 \\
\hline 46 & 4.43 & 2.26 & 18.6 & 42 \\
\hline 47 & 4.21 & 2.79 & 18.6 & 27 \\
\hline 49 & 5.53 & 3.32 & 14.8 & 34 \\
\hline 52 & 5.63 & 3.50 & 19.3 & 41 \\
\hline 56 & 5.20 & 2.21 & 18.2 & 56 \\
\hline 57 & 3.59 & 2.43 & 18.0 & 21 \\
\hline
\end{tabular}

(1) Denitritication rate based on an initial bed volume of $23.2 \mathrm{dm}^{3}$. 
portions of the column, respectively. These MLSS values are significantly higher than the maximum MLSS values of $5.55 \mathrm{~kg} / \mathrm{m}^{3}$ observed in stirred-bed reactors fed $\mathrm{NH}_{4} \mathrm{NO}_{3}$. (5) With the 1.6-cm-diameter Raschig ring, microbial growth fills the center of the ring and reduces the surface area exposed to nitrate solution. Possibly, larger-diameter rings would be more effective for long-term use.

\section{Methanol Utilization}

Numerous denitrification studies at low nitrate concentrations $\left(<250 \mathrm{~g} \mathrm{NO}_{3}^{-} / \mathrm{m}^{3}\right)$ have shown that $0.6 \mathrm{~g}$ of methanol is required to denitrify one gram of nitrate. $(6,7)$ This work, at high nitrate concentrations $\left(>1000 \mathrm{~g} \mathrm{NO}_{3}^{-} / \mathrm{m}^{3}\right)$, indicates that less $\mathrm{CH}_{3} \mathrm{OH}$ is required

Table 7

DENITRIFICATION METHANOL HEUUIKEIVIEIVTTS

\begin{tabular}{llc}
\hline \multicolumn{1}{c}{ Packing Type } & $\begin{array}{c}\mathrm{CH}_{3} \mathrm{OH} \\
\text { Utilization } \\
\left(\mathrm{g} \mathrm{CH}_{3} \mathrm{OH}_{\mathrm{g} \mathrm{NO}}{ }^{-}\right)(1)\end{array}$ & $\begin{array}{c}\text { 3alimple } \\
\text { Number }\end{array}$ \\
\hline Anthracite in the Columnar Column & $0.48 \pm 0.35(2)$ & 18 \\
Anthracite in the Tapered Column & $0.45 \pm 0.14$ & 16 \\
Polypropylene Raschig Rings & $0.29+0.14$ & 14 \\
\hline
\end{tabular}

(1) Grams of $\mathrm{CH}_{3} \mathrm{OH}$ required to denitrify one gram of nitrate.

(2) Standard deviation.
(Tahle 7). The stoichiometric $\mathrm{CH}_{3} \mathrm{OH}$ requirement to denitrily one gram of nitrato is $0.43 \mathrm{~g}$ $\mathrm{CH}_{3} \mathrm{UH}$; however, i.l dees not provide sufficient carbon for microbial growlh ur deoxygenation of any dissolved oxygen present in the system.

The $\mathrm{CH}_{3} \mathrm{OH}$ requirement for denitrification with Raschig-ring packing appears to be approxi-

mately $60 \%$ lower than with the anthracite packing (Table 7). In the case where 1.6-cm-diameter polypropylene rings were used for packing, excessive microbial growth caused hydraulic short circuiting in the column which resulted in appreciably lower denitritication rates after operation of the unit in excess of 40 days. The $\mathrm{CH}_{3} \mathrm{OH}$ utilization constant observed with the polypropylene rings was below the stoichiometric $\mathrm{CH}_{3} \mathrm{OH}$ requirement for denitritication, indicating that the microbial biomass (maximum of $83 \mathrm{~kg}$ $\mathrm{MLSS} / \mathrm{m}^{3}$ at the bottom of the column) was being utilized as an endogeneous carbon source. The $\mathrm{CH}_{3} \mathrm{OH}$ requirement decreased in proportion to the length of operation (Figure 4).

It appears that denitrification at high nitrate concentrations requires approximately $25 \%$ less $\mathrm{CH}_{3} \mathrm{OH}$ than denitrification at low nitrate substrate concentrations. For example, the work of McCarty $(0)$ and 'smith, (7) whore nitrate substrate concentrations were in the order of $5-10 \mathrm{~g}$ $\mathrm{NO}_{3}-/ \mathrm{m}^{3}$, required $0.6 \mathrm{~g}$ of $\mathrm{CH}_{3} \mathrm{OH} / \mathrm{g}$ of $\mathrm{NO}_{3}{ }^{-}$while, in this work, where nitrate substrate concentrations were on the order of $500-5000 \mathrm{~g} \mathrm{NO}_{3}^{-} / \mathrm{m}^{3}$, the $\mathrm{CH}_{3} \mathrm{OH}$ requirement for each gram of nitrate was on the order of 0.4 to $0.5 \mathrm{~g}$.

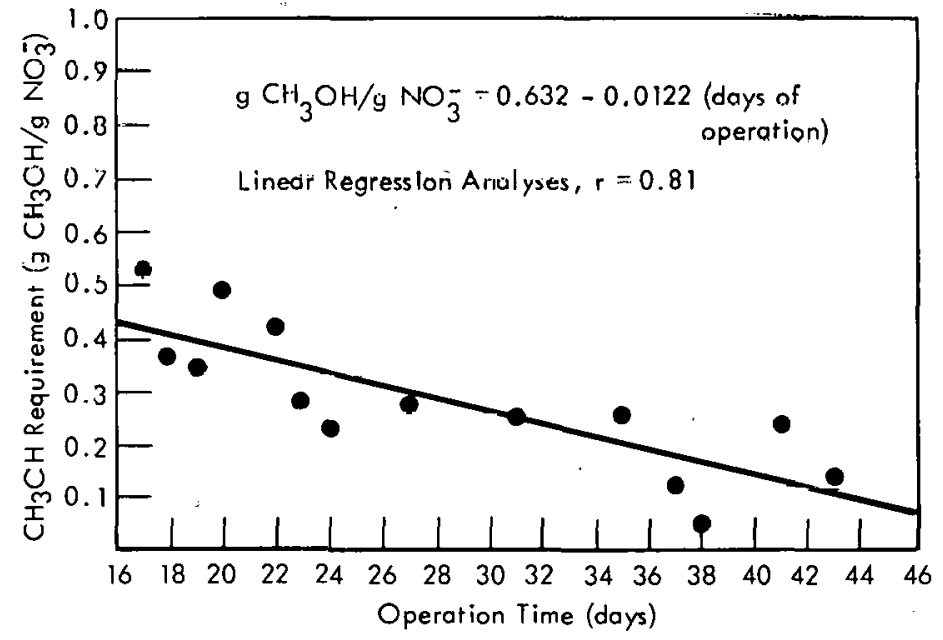

Figure 4. METHANOL UTILIZATION AS A FUNCTION OF THE TIME OF OPERATION. 


\section{Summary and Conclusions}

Anaerobic columns packed with anthracite coal particles appear to be an effective method for the treatment of nitrate wastes associated with uranium recovery operations which use the ammonium diuranate process. Nitrate wastes generated in this process are predominantly $\mathrm{HNO}_{3}$ and $\mathrm{NH}_{4} \mathrm{NO}_{3}$. The quantity of nitrates in the waste streams from a commercial-scale facility might be expected to be as high as five metric tons of nitrate per day. To denitrify this quantity of nitrate at a denitrification rate of $100 \mathrm{~g} \mathrm{NO}_{3}^{-} / \mathrm{day} / \mathrm{dm}^{3}$, a bed volume of $50 \mathrm{~m}^{3}$ would be required; so, for a bed four meters in diameter, the required height would be slightly more than four meters.

Denitrification kinetic data indicate that the most effective substrate nitrate concentrations are less than $6 \mathrm{~kg} \mathrm{NO}_{3}^{-} / \mathrm{m}^{3}$. If $5 \mathrm{~kg} \mathrm{NO}_{3}^{-} / \mathrm{m}^{3}$ is selected as the influent concentration, the required volume for five metric tons of nitrate per day would be $1000 \mathrm{~m}^{3}$, or a flow rate of $11.6 \mathrm{dm} 3 / \mathrm{s}$. The cross-sectional flow into a 4 by 4 -m-diameter column would be 0.92

$\mathrm{dm}^{3} / \mathrm{m}^{2} / \mathrm{s}$, about 0.4 of that in the tapered column used in these studies. Mechanical stirrers could be used to maintain bed integrity, or the bed could be fluidized in a tapered column by using anthracite of smaller particle size. A recycle system could be used if the $\mathrm{pH}$ levels and ammonium concentrations could be maintained at nontoxic conditions.

Extrapolations of laboratory-bench experiments to production-size facilities are often haphazardous and speculative; however, data presented here certainly justify pilot-plant tests at facilities where the disposal of large quantities of nitrate wastes is a problem.

\section{DENITRIFICATION KINETICS}

\section{Introductiun!}

Denitrification kinetics at low nitrate substrate concentrations has demonstrated that, as long as there is an adequate carbon supply, denitrification rates do not decrease until nitrate concentrations approach less than $0.30 \mathrm{~g} \mathrm{NO}_{3}^{-} / \mathrm{m}^{3} .(8-10)$. At nitrate substrate concentrations greater than $1000 \mathrm{~g} \mathrm{NO}_{3}^{-} / \mathrm{m}^{3}$, the kinetics of denitrification has not been invcstigated. The major purpose in evalualing denitrification kinetics is to determine the nitrate substrate concentrations that will provide optimum denitrification rates for various nitrate sources. In columnar studies it is difficult to properly evaluate denitrification kinetics because the concentration of substrate nitrate in an upward-flow column will decrease with increasing column height. In addition, such parameters as current hydraulic residence times and microbial concentrations should be measured periodically as they likely vary within the column over the interval of the experiment. Microbial concentrations are difficult, if not impossible, to determine without destroying the columnar unit. Thus, in the work described here, continuous-flow, stirred-bed reactors were used to evaluate denitrification kinetics.

\section{Methods and Materials}

Since wastes from $\mathrm{UO}_{2}$ fuel fabrication processes contain large quantities of $\mathrm{NH}_{4} \mathrm{NO}_{3}$, the arnmonium salt was used as one of the nitrate materials. Other nitrate materials were $\mathrm{KNO}_{3}$, $\mathrm{Ca}\left(\mathrm{NO}_{3}\right)_{2}$, and actual nitrate wastes from a $\mathrm{UO}_{2}$ fuel fabrication plant. Methanol was used 
as a carbon source at a rate of $0.6 \mathrm{~g} \mathrm{CH}_{3} \mathrm{OH} / \mathrm{g} \mathrm{NO}_{3}^{-}$. A reactor (illustrated in Figure 5), containing $8.8 \mathrm{dm}^{3}$ of microbial stock solution, was fed influent $\mathrm{NH}_{4} \mathrm{NO}_{3}$ solutions ranging in nitrate concentration from approximately 2 to $15 \mathrm{~kg} \mathrm{NO}_{3}^{-} / \mathrm{m}^{3}$. A smaller reactor $(2.2$ $\mathrm{dm}^{3}$ ) was used to evaluate the influence of $\mathrm{CH}_{3} \mathrm{OH}$ concentrations on denitrification rates and establish specific removal rates for $\mathrm{Ca}\left(\mathrm{NO}_{3}\right)_{2}$. A combination magnetic stirrer/hot plate was used to maintain a stirred suspension of microbial solids at a reactor temperature of $29 \pm 2^{\circ} \mathrm{C}$. Influent was pumped from a $40-\mathrm{dm}^{3}$ calibrated teed reservolr at a flow rate of $0.31 \mathrm{dm} 3 / \mathrm{hr}$. Four influent concentrations of $\mathrm{NH}_{4} \mathrm{NO}_{3}$, in the following successive order, were used: $2.2,5.0,12$, and $15 \mathrm{~kg} \mathrm{NO}_{3}^{-} / \mathrm{m}^{3}$.

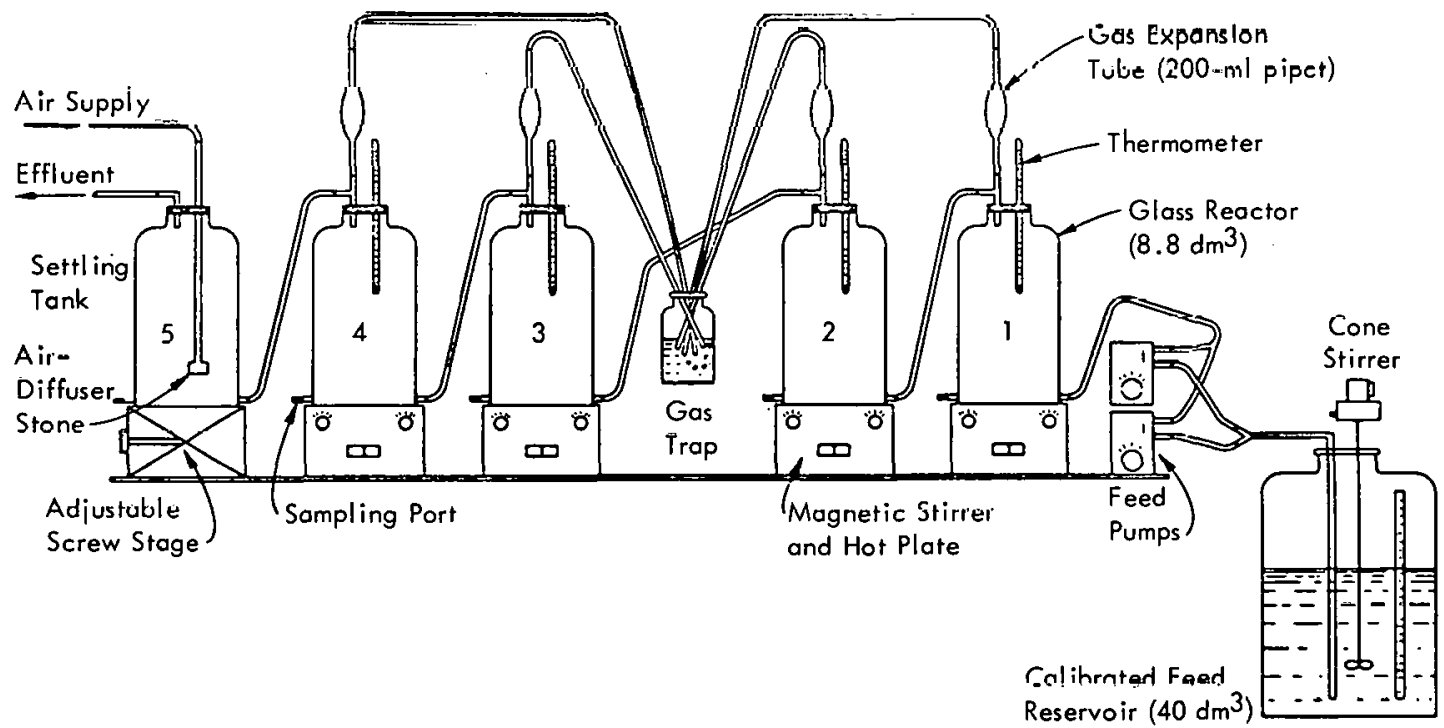

Figure 5. r..NTINIINIISFI OW. STIRRED-BED REACTOR SYSTEM,

Specific removal rates, $U$, were determined after three mean hydraulic residence times $(d)$ and expressed in days ${ }^{-1}$ :

$$
U=\frac{C_{i}-C_{r}}{\gamma \times},
$$

whére:

$C_{1}$ represents the influmnt nitrntr. conncontrotion in $\mathrm{kg} \mathrm{NO}_{3}^{-} / \mathrm{m}^{3}$,

$\mathrm{C}_{\mathrm{r}}$ the reactor nitrate concentration in $\mathrm{kg} \mathrm{NO}_{3}-/ \mathrm{m}^{3}$,

$\boldsymbol{\gamma}$ the mean hydraulic residence time, in days, and

$x \quad$ the mixed liquor volatile suspended solids, in $\mathrm{kg} / \mathrm{m}^{3}$.

(d) Mean hydraulic residence time is determined by the volume of the reactor divided by the flow rate- 1.2 days. 
Nitrate determinations were made by the method of Francis and Malone ${ }^{(5)}$ and nitrite was determined colorimetrically by the method of Bremner. (2) Mixed liquor volatile suspended solids (MLVSS) were determined after filtering aliquots of the reactor mixed liquor through preheated $\left(550^{\circ} \mathrm{C}\right.$ for $0.5 \mathrm{hr}$ ) Gelman glass fiber Type A filters. After drying to $110^{\circ} \mathrm{C}$ for one hour, the weight loss at $550^{\circ} \mathrm{C}$ after 0.5 hour was expressed as MLVSS (in $\mathrm{kg} / \mathrm{m}^{3}$ ). The concentrations of MLVSS as a function of time is presented in Figure 6. MLVSS values not measured directly were taken from this curve.

\section{Results and Discussion}

The kinetics of denitrification was evaluated using Lineweaver-Burk plots. (11) The Lineweaver-Burk equation is derived from the Michaelis and Menten relationship:

$$
U=U_{\max }(S) /\left[K_{S}+(S)\right]
$$

where:

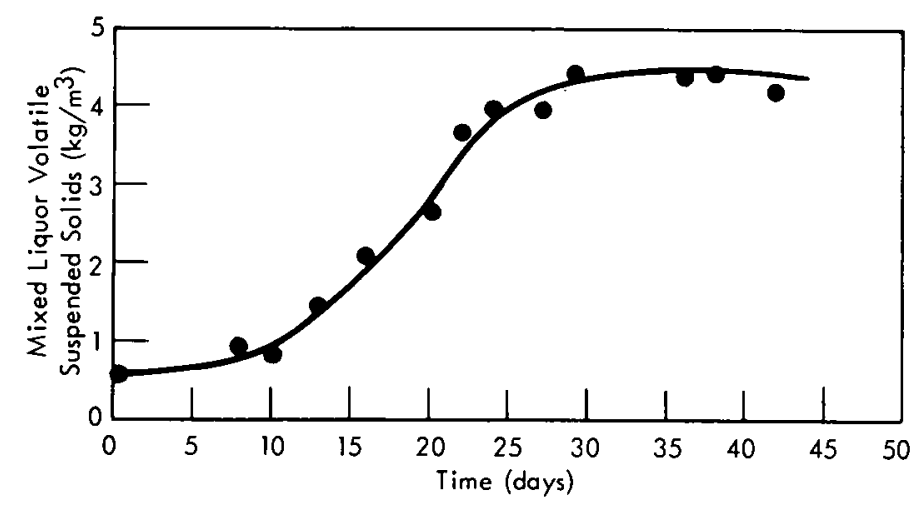

$U_{\max }$ represents the maximum specific removal rate, Figure 6. MIXED LIQUOR VOLATILE SUSPENDED SOLIDS GROWTH CURVE. in days ${ }^{-1}$,

(S) the nitrate substrate concentration, in $\mathrm{kg} \mathrm{NO}_{3}^{-} / \mathrm{m}^{3}$, and

$K_{s}$ the Michaelis-Merilen curstant, which is equal to the nitrate concentration at $1 / 2 \cup_{\max }$.

The Lineweaver-Burk equation:

$$
(S) / U=(S) / U_{\max }+K_{S} / U_{\max }
$$

is formed by taking the reciprocal of both sides of Equation 1 and multiplying the equation by (S). Thus, $U_{\max }$ and $K_{S}$ can be solved graphically by plotting $(S) / U$ on the linear ordinate as a function of $(S)$ on the abscissa. The intercept is $K_{S} / U_{\max }$ and the slope is $1 / U_{\max }$. The Lineweaver-Burk equation is more appropriate for $U_{\max }$ and $K_{s}$ determinations at high substrate concentrations than the Michaelis-Menten equation. $(7,10,11)$

Specific removal rates, $U$, for $\mathrm{NH}_{4} \mathrm{NO}_{3}$ ranged from 1.94 days ${ }^{-1}$ at $3.99 \mathrm{~kg} \mathrm{NO} 3^{-} / \mathrm{m}^{3}$ to 0.70 day $^{-1}$ at $9.30 \mathrm{~kg} \mathrm{NO} 3^{-} / \mathrm{m}^{3}$ (Table 8). Plotted in the form (S) $/ \mathrm{U}$ as a function of (S) resulted in a concave upward curve at nitrate substrate concentrations greater than $6 \mathrm{~kg}$ $\mathrm{NO}_{3}{ }^{-} / \mathrm{m}^{3}$ (Figure 7). At substrate concentrations less than $6 \mathrm{~kg} \mathrm{NO}_{3}^{-} / \mathrm{m}^{3}$, linear regression anlalyses $(r=0.992)$ resulted in a value for $U_{\max }$ of 1.79 days $s^{-1}$, a value slightly higher than the 1.37 days $^{-1}$ reported by Moore and Schroeder. (8) 
Table 8

DENITRIFICATION SPECIFIC REMOVAL RATES AT VARIOUS EFFLUENT NITRATE CONCENTRATIONS

(Using $\mathrm{NH}_{4} \mathrm{NO}_{3}$ Solutions in a Continuous.Flow, Stirred Bed Reactor; Reactor Volume $=8.8 \mathrm{dm}^{3}$, Flow Rate $=0.31 \mathrm{dm}^{3} / \mathrm{hr}$ )

\begin{tabular}{|c|c|c|c|c|}
\hline \multicolumn{2}{|c|}{$\begin{array}{c}\text { Nitrate } \\
\text { Concentration } \\
\left.(\mathrm{kg} \mathrm{NO})_{3}^{-} / \mathrm{m}^{3}\right) \\
\end{array}$} & \multirow{2}{*}{$\begin{array}{c}\text { Hydrogen Ion } \\
\text { Concentration } \\
\qquad(\mathrm{pH})\end{array}$} & \multirow{2}{*}{$\begin{array}{c}\text { Mixed Liquor } \\
\text { Volatile Suspended } \\
\text { Solids } \\
\left(\mathrm{kg} / \mathrm{m}^{3}\right)\end{array}$} & \multirow{2}{*}{$\begin{array}{c}\text { Specific Removal } \\
\text { Rate, } r^{(1)} \\
\text { (days }^{-1} \text { ) }\end{array}$} \\
\hline Influent & Effluent & & & \\
\hline 2.44 & 1.42 & 8.26 & 0.64 & 1.33 \\
\hline 2.88 & 0.07 & 8.58 & 1.43 & 1.64 \\
\hline 11.5 & 3.99 & 8.35 & 3.22 & 1.94 \\
\hline 13.3 & 5.98 & 8.34 & 3.64 & 1.68 \\
\hline 13.3 & 9.30 & 8.25 & 3.96 & 0.84 \\
\hline 12.0 & 7.97 & 8.27 & 4.00 & 0.82 \\
\hline 15.0 & 9.71 & 8.28 & 4.35 & 1.01 \\
\hline 12.8 & 9.30 & 8.28 & 4.10 & 0.70 \\
\hline 15.9 & 8.86 & 8.26 & 4.19 & 1.76 \\
\hline 5.1 & 0.38 & 8.53 & 4.36 & 0.90 \\
\hline 5.1 & 0.01 & 8.58 & 4.20 & 1.01 \\
\hline
\end{tabular}

The increasing upward curvature of the line in Figure 7 at nitrate substrate concentrations greater than $6 \mathrm{~kg}$ $\mathrm{NO}_{3}-/ \mathrm{m}^{3}$ is indicative of denitrification kinetics resulting from excessive nitrate substrate concentrations. (11) It, thus, appears from Figure 7 that nitrate substrate concentrations in excess of $6 \mathrm{~kg}$ $\mathrm{NO}_{3}{ }^{-} / \mathrm{m}^{3}$ inhibit the denitrification rate. However, other constituents, such as excessive concentrations of the rarbon substrate $\left(\mathrm{CH}_{3} \mathrm{OH}\right)$ or ammon. ium, might be responsible for the observed decrease in the denitrification rates.

The ratio of $\mathrm{CH}_{3} \mathrm{OH}$ to nitrate was maintained constant in the influent at $0.6 \mathrm{~g} \mathrm{CH}_{3} \mathrm{OH} / \mathrm{g}$ of $\mathrm{NO}_{3}{ }^{-}$throughout the study. Thus, $\mathrm{CH}_{3} \mathrm{OH}$ concentrations at nitrate substrate concentrations of $10 \mathrm{~kg} \mathrm{NO} 3^{-} / \mathrm{m}^{3}$ would be on the order to $6 \mathrm{~kg} \mathrm{CH} \mathrm{CH}_{3} \mathrm{OH} / \mathrm{m}^{3}$ if $0.6 \mathrm{~g}$ of $\mathrm{CH}_{3} \mathrm{OH}$ was oxidized for each gram of $\mathrm{NO}_{3}^{-}$denitrified. To test the influence of $\mathrm{CH}_{3} \mathrm{OH}$ substrate concentrations on the rate of denitrification, specific removal rates, $r$, were determined at $\mathrm{CH}_{3} \mathrm{OH}$ substrate concentrations ranging from 1.41 to $11.6 \mathrm{~kg}$ $\mathrm{CH}_{3} \mathrm{OH} / \mathrm{m}^{3}$ while maintaining the nitrate substrate concentration less than $5.0 \mathrm{~kg} \mathrm{NO} 3^{-} / \mathrm{m}^{3}$. The high linear regression coefficient $(r=0.973)$ between (S)/U and (S) in Figure 8, where (S) in this case represented $\mathrm{CH}_{3} \mathrm{OH}$ substrate concentrations as high as $10 \mathrm{~kg}$ $\mathrm{CH}_{3} \mathrm{OH} / \mathrm{m}^{3}$, indicated that excessive $\mathrm{CH}_{3} \mathrm{OH}$ substrates were not

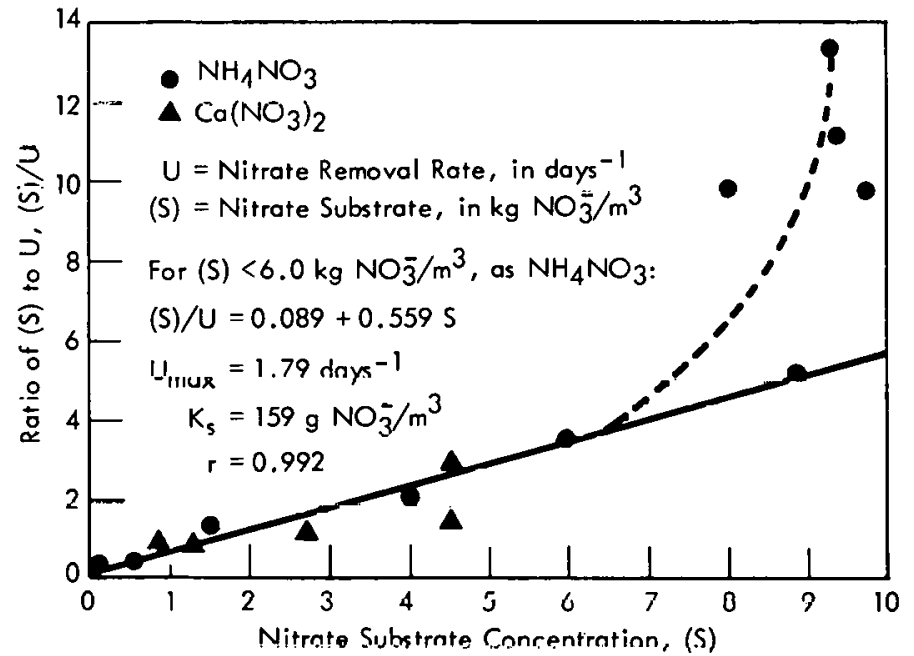

Figure 7. LINEWEAVER-BURK PLOTS, USING NITRATE AS A SUBSTRATE. responsible for the observed inhibition in denitrification rates at nitrate substrate concentrations greater than $6 \mathrm{~kg}$ $\mathrm{NO}_{3}{ }^{-} / \mathrm{m}^{3}$. IIncidentally, $10 \mathrm{~kg} \mathrm{CH} 3_{3} \mathrm{OH} / \mathrm{m}^{3}$ is more than twice that of any $\mathrm{CH}_{3} \mathrm{OH}$ substrate concentration observed during the evaluation of nitrate substrates on the denitrification rate.) The negative intercept $(-0.07$ in Figure 8$)$, resulted in a negative Michaelis-Menten value for $\mathrm{CH}_{3} \mathrm{OH}\left(-164 \mathrm{~g} / \mathrm{m}^{3}\right)$ and might imply some inhibition in the denitrification rate. However, the $\mathrm{U}_{\max }$ value determined at various $\mathrm{CH}_{3} \mathrm{OH}$ concentrations 
(Figure 8) was approximately $30 \%$ higher than $U_{\max }$ determined from the nitrate substrate concentrations below $6 \mathrm{~kg} \mathrm{NO} 3^{-} / \mathrm{m}^{3}$ (Figure 7), indicating that the negative intercept was due to statistical variation rather than any inhibition of $\mathrm{CH}_{3} \mathrm{OH}$ on the denitrification rate.

Maximum ammonium concentrations. using $\mathrm{NH}_{4} \mathrm{NO}_{3}$ influents in stirred-bed reactors at nitrate substrate concentrations between 7 and $10 \mathrm{~kg} \mathrm{NO}_{3}^{-} / \mathrm{m}^{3}$ were approximately $3.3 \mathrm{~kg} \mathrm{NH}{ }_{4}^{+} / \mathrm{m}^{3}$ (Table 8). Specific removal rates obtained after adding $\left(\mathrm{NH}_{4}\right)_{2} \mathrm{SO}_{4}$ to $\mathrm{NH}_{4} \mathrm{NO}_{3}$ influents and lowering the $\mathrm{pH}$ with concentrated $\mathrm{H}_{2} \mathrm{SO}_{4}$ revealed a synergistic effect between the mixed liquor $\mathrm{pH}$ and the $\mathrm{NH}_{4}{ }^{+}$concentrations Table 9). For example, at approximately the same $\mathrm{NH}_{4}{ }^{+}$concentrations, as the $\mathrm{pH}$ of the mixed liquor was decreased, the rate of denitrification increased sharply, implying that the inhibition was not due to $\mathrm{NH}_{4}{ }^{+}$concentrations per se but due to ammonia concentrations herause of the equilibrium rear.tion:

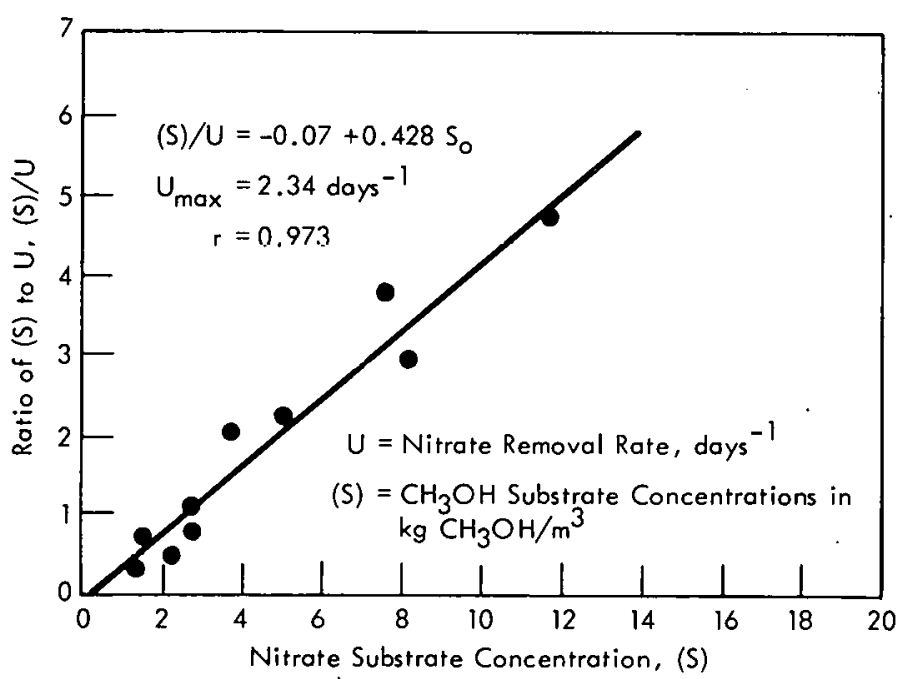

Figure 8. LINEWEAVER-BURK PLOTS, USING METHANOL AS A SUBSTRATE.

where: $K_{d}=\left(\mathrm{NH}_{3}\right)(\mathrm{H}) /\left(\mathrm{NH}_{4}{ }^{+}\right)=5.52 \times 10^{-10}$. Thus, the inhibition in denitrification observed in Figure 7 may be due to $\mathrm{NH}_{3}$ toxicities rather than excessive nitrate substrate

Table 9

INFILIJENCE OF AMMONIUM ION CONCENTRATIONS AND $\mathrm{pH}$ OF THE MIXED LIQUOR ON THE DENITRIFICATION SPECIFIC REMOVAL RATE

(Nitrate Substrate Concentration $<3 \mathrm{~kg} \mathrm{NO} 3^{\left.-/ \mathrm{m}^{3}\right)}$

\begin{tabular}{ccc}
$\begin{array}{c}\text { Mixed Liquor } \\
\begin{array}{c}\mathrm{NH}_{4}{ }^{-} \\
\left(\mathrm{kg} / \mathrm{m}^{3}\right)\end{array}\end{array}$ & $\begin{array}{c}\text { Specific Removal } \\
\text { Rate } \\
\text { (days }\end{array}$ \\
\hline 3.3 & 8.0 & 0.85 \\
3.3 & 7.1 & 2.63 \\
3.6 & 6.8 & 4.68 \\
\hline
\end{tabular}
concentrations, since the averaged mixed-liquor $\mathrm{pH}$ value from 25 observations was $8.34 \pm 0.16$.

To test if concentrations of nitrate in excess of $6 \mathrm{~kg}$ $\mathrm{NO}_{3}-/ \mathrm{m}^{3}$ inhibited the rate of denitrification in the absence of the ammonium ion, $\mathrm{Ca}\left(\mathrm{NO}_{3}\right)_{2}$ and $\mathrm{KNO}_{3}$ solutions were used as influents. In addition, specific removal rates were determined at substrate concentrations less than $6 \mathrm{~kg} \mathrm{NO}_{3}^{-} / \mathrm{m}^{3}$ for some $\mathrm{UO}_{2}$ fuel nitrate wastes. These wastes were made predominately of $\mathrm{NH}_{4} \mathrm{NO}_{3}$ and $\mathrm{HNO}_{3}$ neutralized to a $\mathrm{pH}$ of 6.4 with $\mathrm{CaCO}_{3}$. The difference in chemical composition between the $\mathrm{UO}_{2}$ fuel nitrate wastes and $\mathrm{NH}_{4} \mathrm{NO}_{3}$ was rather subtle (ie, the ratio of nitrate to ammonium, on the weight basis, in the $\mathrm{UO}_{2}$ nitrate wastes was approxi- 
mately 5 to 1 rather than 3.5 to 1 as in ammonium nitrate). The calcium concentration in the influents made of $\mathrm{UO}_{2}$ fuel nitrate wastes was about $600 \mathrm{~g} \mathrm{Ca}+2 / \mathrm{m}^{3}$ after dilution to the desired nitrate concentrations with spring water, while the calcium ion concentration in the $\mathrm{NH}_{4} \mathrm{NO}_{3}$ influents was less than $20 \mathrm{~g} \mathrm{Ca}^{+2} / \mathrm{m}^{3}$.

There appeared to be little difference in the specific removal rates between $\mathrm{NH}_{4} \mathrm{NO}_{3}$ or $\mathrm{Ca}\left(\mathrm{NO}_{3}\right)_{2}$ at concentrations above or below $6 \mathrm{~kg} \mathrm{NO} 3^{-} / \mathrm{m}^{3}$ (Table 10). Specific removal rates for $\mathrm{Ca}\left(\mathrm{NO}_{3}\right)_{2}$ at substrate nitrate concentrations less than $6 \mathrm{~kg} \mathrm{NO} \mathrm{N}^{-} / \mathrm{m}^{3}$ were slightly larger than, though not significantly different from, the removal rates for $\mathrm{NH}_{4} \mathrm{NO}_{3}$. The very low removal rates with $\mathrm{Ca}\left(\mathrm{NO}_{3}\right)_{2}$ at substrate concentrations greater than $6 \mathrm{~kg}$ $\mathrm{NO}_{3}^{-} / \mathrm{m}^{3}$ suggests that denitrification was substrate inhibited. Since only two measurements were made, additional work should be carried out to verify the existance of the inhitition.

Removal rates at substrate concentrations greater than $6 \mathrm{~kg} / \mathrm{NO}_{3}^{-}$, using $\mathrm{KNO}_{3}$, were significantly higher than at similar nitrate substrate concentrations using eitier $\mathrm{Ca}\left(\mathrm{NO}_{3}\right)_{2}$ or $\mathrm{NH}_{4} \mathrm{NO}_{3}$. However, the average removal rate was not as high as the average removal rates for $\mathrm{Ca}\left(\mathrm{NO}_{3}\right)_{2}$ and $\mathrm{NH}_{4} \mathrm{NO}_{3}$ at substrate concentrations less than $6 \mathrm{~kg} \mathrm{NO}_{3}^{-} / \mathrm{m}^{3}$.

The highest average specific removal rate was observed using $\mathrm{UO}_{2}$ tuel nitrate waste at substrate concentrations less than 6 $\mathrm{kg} \mathrm{NO} 3^{-} / \mathrm{m}^{3}$ (Table 10). This rate is approximately ten times that determined by Requa and Schroeder (9) in a packed-bed reactor, and over twice that reported by Moore and Schroeder $(8)$ in stirred-bed reactors.
Table 10

SPECIFIC REMOVAL RATES AS INFLUENCED BY THE NITRATE SOURCE AND CONCENTRATION (After Three Hydraulic Residence Times)

\begin{tabular}{lccc}
\hline $\begin{array}{c}\text { Source } \\
\text { of Nitrate }\end{array}$ & $\begin{array}{c}\text { Substrate } \\
\text { Concentration } \\
\left(\mathrm{kg} \mathrm{NO}_{3} / \mathrm{m}^{3}\right)\end{array}$ & $\begin{array}{c}\text { Specific Removal } \\
\text { Rate, } \mathrm{U} \\
\left(\text { days }^{-1}\right)\end{array}$ & $\begin{array}{c}\text { Number of } \\
\text { Determinations }\end{array}$ \\
\hline $\mathrm{NH}_{4} \mathrm{NO}_{3}$ & $<6$ & $2.18 \pm 0.80^{(1)}$ & 17 \\
$\mathrm{Ca}\left(\mathrm{NO}_{3}\right)_{2}$ & $>6$ & $1.03 \pm 0.42$ & 5 \\
& $<6$ & $2.30 \pm 1.04$ & 5 \\
$\mathrm{KNO}_{3}$ & $: 6$ & $0.75 \pm 0.20$ & 2 \\
$\mathrm{UO}_{2} \mathrm{Fuel}$ & $>6$ & $\mathrm{Nu}(2)$ & \\
Wastes & $>6$ & $1.85 \pm 0.31(3)$ & 3 \\
& $>6$ & $3.13 \pm 0.56$ & 3 \\
\end{tabular}

(1) Standard deviation.

(2) Nul determined.

(3) Contained an average $\mathrm{NO}_{2}-$ concentration of $2.09 \pm 0.32 \mathrm{~kg} / \mathrm{m}^{3}$ at an average nitrate substrate concentration of $11.5 \pm 0.9 \mathrm{~kg} / \mathrm{m}^{3}$ of nitrate to nitrite.

There is apparently considerable difference in the intermediate denitrification kinetics of nitrate as $\mathrm{NH}_{4} \mathrm{NO}_{3}$ compared to nitrate as $\mathrm{KNO}_{3}$. For example, in the denitrification of $\mathrm{KNO}_{3}$ at substrate nitrate concentrations between $10 \cdot 12 \mathrm{~kg} \mathrm{NO}_{3}^{-} / \mathrm{m}^{3}$, approximately $2 \mathrm{~kg}$ of $\mathrm{NO}_{2}-/ \mathrm{m}^{3}$ were detected in the equilibrium mixed liquor; while, at similar substrate nitrate concentrations as $\mathrm{NH}_{4} \mathrm{NO}_{3}$, less than $10 \mathrm{~g} \mathrm{NO}_{2}^{-} / \mathrm{m}^{3}$ were detected. The intermediate kinetics of the denitrification of $\mathrm{KNO}_{3}$ must be similar to that of $\mathrm{NaNO}_{3}$, as appreciable quantities of $\mathrm{NO}_{2}^{-}$(as high as $1250 \mathrm{~g} \mathrm{NO}_{2}^{-} / \mathrm{m}^{3}$ ) were detected in effluents from columnar denitrification units when influents contained $\mathrm{NaNO}_{3}$ as the nitrate source (Table 2). No significant nitrite concentrations were detected in the stirred-bed reactors 
whose influents were made of $\mathrm{Ca}\left(\mathrm{NO}_{3}\right)_{2}$ until substrate nitrate concentrations exceeded 6 $\mathrm{kg} / \mathrm{m}^{3}$.

\section{Summary and Conclusions}

Continuous-flow, stirred-bed reactors were used to determine the maximum denitrification specific removal rate for $\mathrm{NH}_{4} \mathrm{NO}_{3}$ solutions. Nitrate substrate concentrations ranged from $0.01-9.74 \mathrm{~kg} \mathrm{NO} 3^{-} / \mathrm{m}^{3}$. Through use of Lineweaver-Burk equations, a graphical solution was used to obtain a $U_{\text {max }}$ of 1.79 days ${ }^{-1}$ for nitrate substrates less than $6 \mathrm{~kg} \mathrm{NO} 3^{-} / \mathrm{m}^{3}$. This value is slightly higher than the 1.37 days $^{-1}$ reported by Moore and Schroeder $(8)$ using $\mathrm{NaNO}_{3}$ at reactor concentrations less than $60 \mathrm{~g} \mathrm{NO}_{3}^{-} / \mathrm{m}^{3}$. The Michaelis-Menten constant (159 $\mathrm{g} \mathrm{NO}_{3}^{-} / \mathrm{m}^{3}$ ), determined by the intercept of the Lineweaver-Burk plot, was on the order of 300 times higher than that observed by Moore and Schroeder. At substrate nitrate concentrations greater than $6 \mathrm{~kg} \mathrm{NO}_{3}^{-} / \mathrm{m}^{3}$, denitrification rates appeared to be inhibited. Inhibition may have been a result of either an excessive nitrate substrate or ammonia toxicities at $\mathrm{pH}$ values of the mixed liquor near 8. Data indicated that both inhibition processes likely occurred. Methanol concentrations as high as $11.6 \mathrm{~kg} . \mathrm{CH}_{3} \mathrm{OH} / \mathrm{m}^{3}$ did not inhibit the denitrification rates. The highest specific removal rates recorded $\left(3.13 \pm 0.56\right.$ days $\left.^{-1}\right)$ were with influents made from $\mathrm{NO}_{3}^{-}$fuel fabrication wastes.

Evaluation of maximum nitrate substrate levels that do not inhibit denitrification rates is of little value in regard to applied processes using continuous-flow, stirred-bed reactors, because effluent levels are usually designed to be low enough for direct disposal to the environment. These values, however, are important in applied processes using columnar denitrification, since influent nitrate substrate concentrations should not exceed the inhibiting levels for optimum utilization of the columnar unit. Stirred-bed reactor studies indicated that, for $\mathrm{NH}_{4} \mathrm{NO}_{3}$ and $\mathrm{Ca}\left(\mathrm{NO}_{3}\right)_{2}$ solutions, substrate nitrate concentrations should not exceed $6 \mathrm{~kg} \mathrm{NO} 3^{-} / \mathrm{m}^{3}$. For $\mathrm{NH}_{4} \mathrm{NO}_{3}$ solutions which exceeded $3 \mathrm{~kg} \mathrm{NH} 4^{+} / \mathrm{m}^{3}$, denitrification rates were approximately five times greater at a $\mathrm{pH}$ of 6.8 than at a pH of 8.0 , indicating that ambient $\mathrm{pH}$ should be maintained between 6.5 and 7.0 for best results.

\section{LABORATORY DENITRIFICATION STUDIES}

\section{Introduction}

Table 11

OPERATING DATA ON FOUR TEST REACTORS

\begin{tabular}{lccc}
\hline Reactor & $\begin{array}{c}\text { Total } \\
\text { Test Days }\end{array}$ & $\begin{array}{c}\text { Number of } \\
\text { Satisfactory } \\
\text { Test Days }\end{array}$ & $\begin{array}{c}\text { Maximum } \\
\text { Denitrification } \\
\text { Rate } \\
\left(\mathrm{g} \mathrm{NO}_{3} \text {-/day/dm } 3\right)\end{array}$ \\
\hline Mini I & 84 & 76 & 11.2 \\
Mini II & 88 & 79 & 9.8 \\
Mini III & 149 & 142 & 11.0 \\
Mini IV & $\underline{132}$ & $\underline{131}$ & 7.6 \\
Total & $\mathbf{4 5 3}$ & 428 & 9.9 \\
\hline
\end{tabular}

Stirred-bed reactor studies have been made to determine the feasibility of biologically decomposing nitric acid wastes. Process operating parameters and plant design data were collected during these studies. Excluding startup periods, four test reactors were satisfactorily operated, as reported in Table 11.

As these data indicate, the reactors operated $94.4 \%$ of the test times at an average maximum feed rate of 9.9 grams nitrate per day per $\mathrm{dm}^{3}$ (liter) of reactor solution. This 
feed rate is equivalent to a rate of $935 \mathrm{kgs}$ (2060 lbs) of nitrate per day [341,000 kgs $(752,000 \mathrm{lbs})$ per year] in the production-sized $94.5-\mathrm{m}^{3}(25,000$-gal) reactor. The operational data on each of the reactors are discussed in subsequent sections of this report.

\section{Equipment}

Continuous-Flow Stirred-Bed Reactors - The waste nitrate stream at the Y-12 Plant will contain a high level of aluminum, calcium, and other materials which precipitate as solids at $\mathrm{pH}$ levels of 7.0 (see Reactor Feeds section of the report, Page 28). It was decided that a continuous-flow, stirred-bed reactor design could be used as a denitrification reactor. A miniature version $\left(\sim 0.06 \mathrm{~m}^{3}\right)$ of a standard commerical water-softener vessel was designed (Figure 9). A variable-speed motor drives the agitator, producing a high turbulent mixing area beneath the impeller. The concentrated feed solutions are added in this zone. The
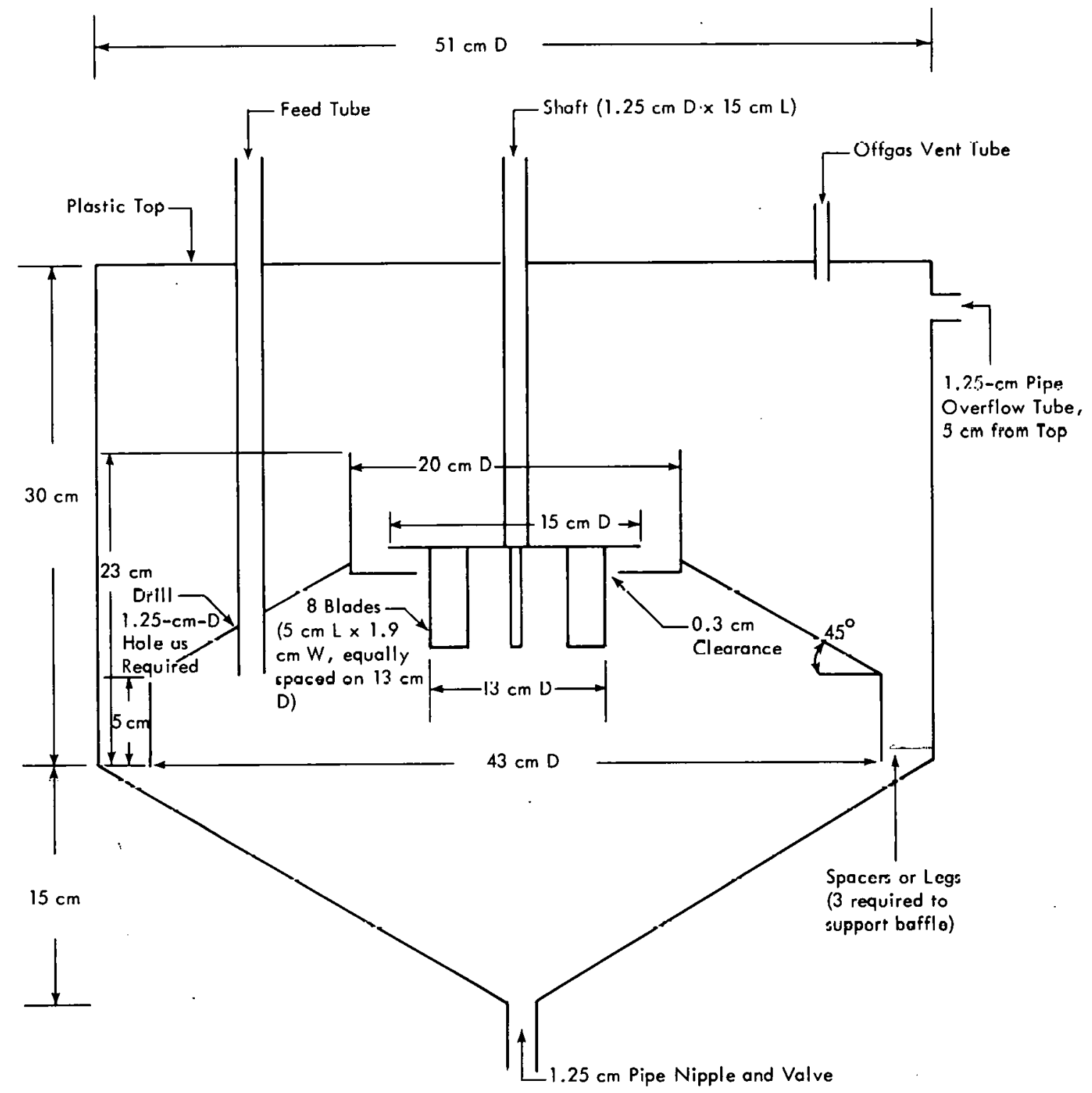

Figure 9. DESIGN OF THE ORIGINAL DENITRIFICATION REACTOR. 
agitator pumps liquids over a baffle in the vessel and creates a relatively quiet zone which permits solids to settle and provides for the continuous withdrawal of the solids from the bottom of the reactor. While this design worked satisfactorily, a later design was also used (Figure 10). In the modified reactor, a nominal 10-cm-wide pocket was welded on top of the inside baffle for the collection of solids. A pipe-and-valve arrangement permitted withdrawal of the solids and eliminated solid withdrawal from the bottom of the reactor.
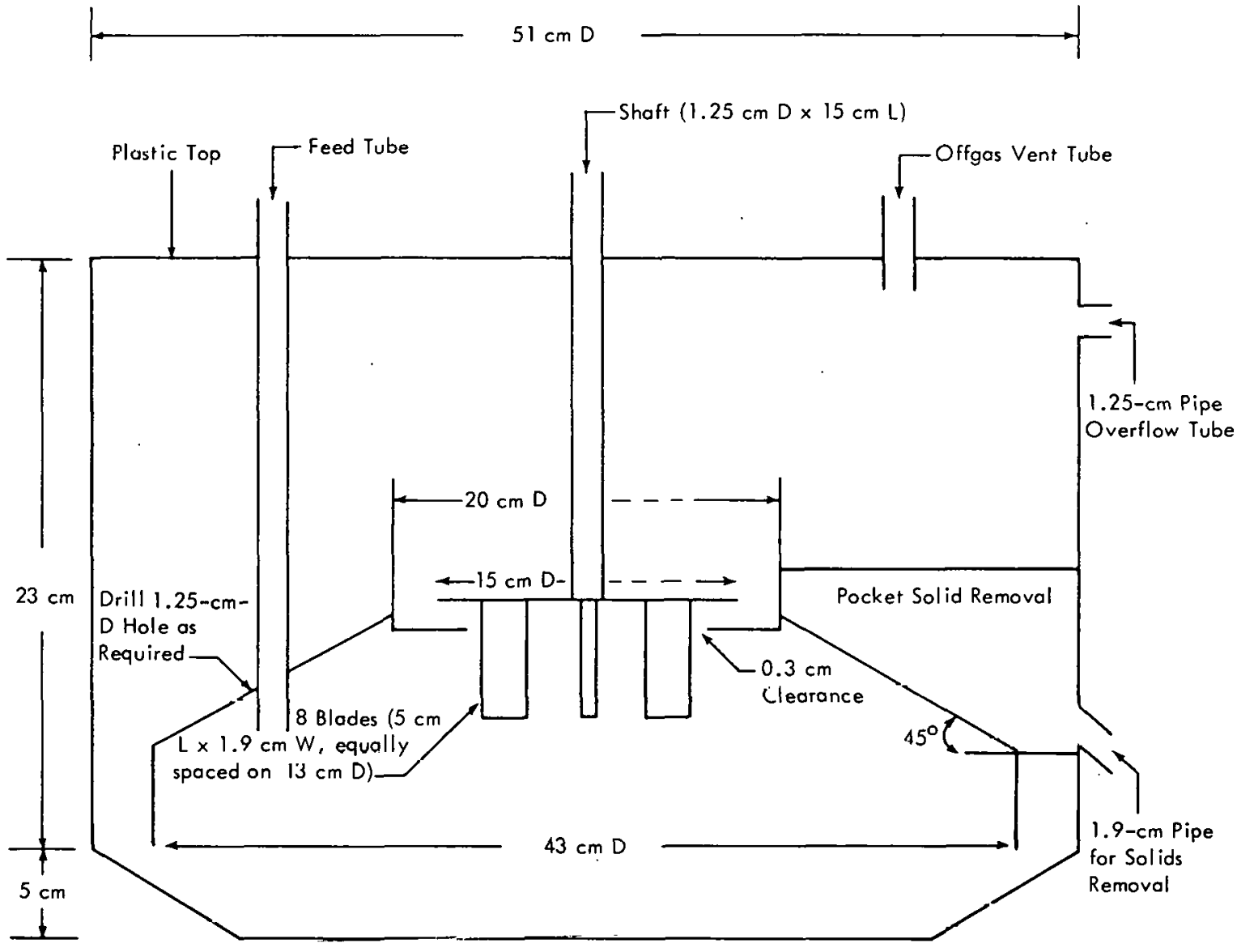

Figure 10. DESIGN OF THE MODIFIED DENITRIFICATION REACTOR.

A plastic cover was installed on top of the reactors to obtain an anaerobic vessel. A vent tube was installed in the cover so that the gases could escape to the atmosphere; also, the volume and composition of the gases could be determined. An inlet feed tube, a thermometer, and a pH electrode were also installed through the plastic cover. In addition, a spare hole was drilled in the cover to permit sampling of the reactor solution. In normal operation, this hole was plugged with a rubber stopper. The impeller agitator shaft passed through the center of the cover and was equipped with a water seal to prevent loss of gases from the reactor. Each entry port and the plastic top were made gas tight using a silastic adhesive.

Mechanically, this type of reactor has operated satisfactorily at solids levels in the reactor up to $6 \mathrm{wt} \%$. Most of the laboratory studies used this reactor design, and the ultimate 
production-size vessel has been designed with the solids withdrawn by using the "side-pocket" design.

\section{Reactor Feeds}

Nitrate Feed - The present nitrate waste stream from the $Y-12$ Plant is composed of a stream called "condensates" and another stream called "raffinates". These streams originate from a uranium purification process in the $Y-12$ Plant. The condensate waste stream is approximately a mixture of $10 \%$ nitric acid and $90 \%$ water, plus trace quantities of such impurities as chlorides, fluorides, and soluble organics. It is planned that this stream will be

Tahle 12

I YPILAL AINAL'Y'BI3 OF THE MOTHER LIQUOR

\begin{tabular}{lc}
\hline \multicolumn{1}{c}{ Component } & $\begin{array}{c}\text { Concentration } \\
\text { (wt \%) }\end{array}$ \\
\hline Aluminum & 4.4 \\
Magnesium & 0.4 \\
Calciurit & 0.8 \\
Sodium & 0.2 \\
Potassium & $0.01-0.1$ \\
Lithium & $0.01-0.1$ \\
Molybdenum & $0.01-0.1$ \\
Zirconium & $0.01-0.1$ \\
Silicon & $0.01 \cdot 0.1$ \\
Nickel & U.U1 -0.1 \\
Fluorides & 0.5 \\
Free Nitric Acid & 3.5 \\
Total Nitrate & 33.0 \\
Wattel & 59.1 \\
\hline
\end{tabular}
evaporated and the nitric acid will be recycled back: to the urdniuri purification systcrr willout any biological treat ment The reffinde sli eam contains a high level of aluminum nitrate, calcium nitrate, and nitric acid, plus impurities extracted in the uranium purification process. It is planned to process this stream through a crystallization operation, and purified aluminum nitrate nanohydrate solids will be recycled for reuse in the uranium purification plant. A waste stream (labeled "mother liquor") from this operation will be generated and will have the typical composition listed in Table 12. This stream, containing a high level of aluminum, calcium, and other impurities, cannot be economically recycled back to the uranium purification plant. This mother-liquor stream will be the nitrate feed solution used in the production denitrificaliun plans.

During the development stages of the biodenitrification processs, a valiety of nitrate and organic foods was used. A commerical grade of calcium nltrate contairing atuul $4.0 \mathrm{wt}$ $\%$ ammonium nitrate was also used in some tests. However, the raffinate solution from the uranium purification plant was used as the source of nitrate for a majority of the continuous-flow, stirred-bed reactor studies. In the early stages, the raffinate solution was neutralized with lime prior to adding it to the reactors. Later studies have used raffinate with neutralization occurring in the reactor vessel by the reaction of the raffinate feed solution with calcium carbonate which is produced in the reactor vessel.

The raffinate stream does not have a constant chemical composition. As noted in Table 13, three different batches had significant variations in the amounts of calcium, aluminum, free nitric acid, and the total nitrate level. Once the production recycle plant is operational, some of the day-to-day variations will be present, and significant long-term changes in the impurity levels can be expected.

Organic Feed-Organic carbon sources used in the batch and column process development studies have included methyl alcohol, calcium acetate, and one experimental batch using sucrose. All of the continuous-flow, stirred-bed reactors have used calcium acetate as the organic feed source. The work of McCarty, et al, (6) showed that the acetate ion was an effective carbon source. 
Table 13

RAFFINATE ANALYSIS

\begin{tabular}{lccc}
\hline & \multicolumn{3}{c}{ Concentration (wt \%) } \\
\cline { 2 - 4 } Component & Batchl 1 & Batch 2 & Batch 3 \\
\hline Aluminum & 2.36 & 2.10 & 3.06 \\
Calcium & 0.29 & 1.70 & \\
Magnesium & 0.2 & 1.30 & \\
Fluorine & 0.24 & - & \\
Sodium & - & 0.03 & \\
Lithium & - & 0.04 & \\
Potassium & $\cdot$ & 0.002 & \\
Free Nitric Acid & 9.24 & 8.32 & 4.90 \\
Total Nitrate & 30.5 & 31.1 & 29.04 \\
Uranium $(\mu g / g)$ & 0.06 & 0.06 & 0.01 \\
Specific Gravity & 1.280 & - & 1.273 \\
\hline
\end{tabular}

In most of the stirred-bed experiments, the organic carbon was added to the raffinate feed solution as a calcium acetate solution. A typical analysis of a water solution of calcium acetate is noted in Table 14. Acetic acid and water were neutralized with agricultural-grade lime to obtain the calcium acetate solutions.

Reactor Feed Solutions-For the continuous-flow, stirred-bed reactor experiments, the majority of the feed solutions were made by mixing raffinate solution with an aqueous solution of calcium acetate. Total nitrate level was in the range of 10 to $13.5 \mathrm{wt} \%$, and the total organic carbon level was in the range of 0

to $3.9 \mathrm{wt} \%$. The organic carbon level was varied to study the $\mathrm{C} / \mathrm{N}$ mole ratio, which will be discussed later in this report. The chemical compositions of several feed batches are given in Table 15. The feeds showing 0.3 to 0.58 wt $\%$ ammonium ion were made using commerical-grade calcium nitrate which contained ammonium nitrate as an impurity. The feeds showing no ammonium ion were made using plant raffinate solution.

Carbon-to-Nitrogen Mole Ratio-A source of organic carbon is required to provide the energy required for a bacterial reduction of nitrates. It is believed that nitrate reduction is coupled to the metabolism of the organisms involved, and the nitrate ion acts as the terminal hydrogen acceptor in the energy transport system. When an adequate concentration of a degradable organic material is present, many types of facultative bacteria are capable of nitrate reduction under anaerobic, or near anaerobic, conditions.

Several uryalic curmpounds have been shown to be a satisfactory carbon source. Methanol is commonly used because of engineering economics, ease of handling, and availability. McCarty, et al, (6) showed that methanol, ethanol, acetone, sugar, and neutralized acetic acid could be used in the denitrification process. For the $Y-12$ studies it was decided that methanol and acetic acid, neutralized with lime, would be used to determine if the acetate carbon would produce higher denitrification rates using nitrate wastes from the $Y-12$ Plant. Table 16 lists the chemical equations which are believed to be valid for the methanol/calcium nitrate and calcium acetate/calcium nitrate reactions. The $\mathrm{C} / \mathrm{N}$ weight ratio from the calcium acetate/calcium nitrate equation is shown to be 1.39 .

During the continuous-flow experiments, a number of feed batches were used which had a $\mathrm{C} / \mathrm{N}$ weight ratio of 1.3 to 1.65 . While using these feeds, the carbon level in the reactor vessel always increased to about 0.4 wt \%. Some tests weie made al reduced $\mathrm{C} / \mathrm{N}$ mole ratios, and it is now believed that an approximate $1.2 \mathrm{C} / \mathrm{N}$ weight ratio in the feed would be preferable. The carbon-to-nitrogen ratio is further discussed in later sections of this report. 
Table 15

COMPOSITICAN OF TH' FEED SOLUTIONS

\begin{tabular}{|c|c|c|c|c|c|c|c|c|c|c|c|c|c|c|c|}
\hline \multirow{2}{*}{$\begin{array}{l}\text { Feed } \\
\text { Number }\end{array}$} & \multirow{2}{*}{$\begin{array}{c}\mathrm{NO}_{3}-\text { Concentration } \\
\text { (vol \%) }\end{array}$} & \multicolumn{3}{|c|}{ Concentration (wt \%) } & \multirow{2}{*}{$\begin{array}{c}\mathrm{C} / \mathrm{N}(2) \\
\text { (wt ratio) }\end{array}$} & \multirow{2}{*}{$\begin{array}{c}\text { Fydrogen lon } \\
\text { Concentration } \\
(\mathrm{pH})\end{array}$} & \multirow{2}{*}{$\begin{array}{l}\text { Density } \\
\left(\mathrm{g} / \mathrm{cm}^{3}\right)\end{array}$} & \multicolumn{8}{|c|}{ Concentration (wt \%) } \\
\hline & & $\overline{\mathrm{NO}_{3}}-$ & $\mathbf{N}$ & TOC 11 & & & & $\mathrm{NH}_{4}{ }^{+}$ & $\mathrm{Ca}$ & Mlg & $\mathrm{Al}$ & $\mathrm{Na}$ & $K$ & $\mathrm{Li}$ & $\mathrm{Fe}$ \\
\hline F-7 & 11.52 & 10.08 & 2.27 & 1.29 & 0.57 & - & 1.143 & 0.31 & - & - & - & $\cdot$ & - & - & - \\
\hline F-8 & 12.86 & 11.10 & 2.51 & 3.36 & 1.34 & - & 1.158 & 0.58 & - & - & - & - & - & $\cdot$ & - \\
\hline F.9 & 12.10 & 10.51 & 2.37 & 2.67 & 1.13 & - & 1.151 & 0 & - & - & - & - & $\cdot$ & - & $\cdot$ \\
\hline$F-10$ & 12.58 & 10.90 & 2.46 & 4.07 & 1.65 & 3.63 & 1.156 & 0 & - & - & - & - & $\cdot$ & $\cdot$ & - \\
\hline$F-11$ & 12.94 & 11.10 & 2.51 & 3.43 & 1.37 & 6.40 & 1.170 & 0.46 & - & - & $\cdot$ & - & $\cdot$ & $\cdot$ & $\cdot$ \\
\hline$F-12$ & 13.47 & 11.60 & 2.62 & 3.50 & 1.33 & 4.90 & 1.163 & 0 & 3.47 & $D .27$ & 0.92 & 0.035 & 0.02 & 0.006 & 0.11 \\
\hline$F-13$ & 13.88 & 11.90 & 2.69 & 3.04 & 1.13 & - & 1.166 & 0 & 3.54 & 0.27 & 0.94 & 0.034 & 0.02 & 0.007 & 0.12 \\
\hline$F \cdot 14$ & 12.80 & 10.49 & 2.48 & 3.34 & 1.35 & - & 1.158 & 0 & - & - & - & - & $\cdot$ & - & $\cdot$ \\
\hline$F-15$ & 13.71 & 11.80 & 2.66 & 3.52 & 1.32 & 3.45 & 1.165 & 0 & - & - & - & - & - & - & - \\
\hline F-16 & 13.82 & 11.90 & 2.69 & 3.71 & 1.38 & 3.40 & 1.166 & 0 & - & - & - & $\cdot$ & - & - & $\cdot$ \\
\hline F-17 & 14.42 & 12.20 & 2.75 & 3.68 & 1.34 & 3.50 & 1.186 & 0 & - & - & $\cdot$ & - & $\cdot$ & $\cdot$ & $\cdot$ \\
\hline$F-18$ & 14.49 & 12.20 & 2.75 & 3.93 & 1.43 & 3.75 & 1.190 & 0 & 4.25 & 0.60 & 0.60 & 0.01 & 0.001 & 0.02 & 0.01 \\
\hline$F-18 W$ & 13.98 & 12.10 & 2.73 & 0 & - & $\cdot$ & 1.160 & 0 & - & $\cdot$ & - & - & $\cdot$ & - & - \\
\hline$F-19$ & 15.64 & 13.40 & 3.03 & 2.96 & 0.98 & 3.30 & 1.170 & 0 & 3.4 & 0.70 & 1.00 & 0.02 & 0.001 & 0.02 & - \\
\hline$F-20$ & 14.78 & 12.90 & 2.91 & $2.0 E$ & 0.71 & 2.90 & 1.148 & 0 & - & - & - & - & - & - & - \\
\hline$F \cdot 21$ & 14.62 & 12.40 & 2.30 & 3.24 & 1.16 & 3.40 & 1.180 & 0 & - & - & - & - & - & - & - \\
\hline$F-22$ & 16.16 & 13.60 & 3.07 & $3.3 \mathrm{c}$ & 1.10 & 2.90 & 1.187 & 0 & . & - & - & - & - & - & $\cdot$ \\
\hline$F-23$ & 16.04 & 13.50 & 3.05 & 3.32 & 1.09 & 3.50 & 1.187 & 0 & - & - & - & $\therefore$ & - & - & $\cdot$ \\
\hline$F-24$ & 13.70 & 11.80 & 2.56 & 3.5 & 1.32 & 3.30 & 1.160 & 0 & - & $\cdot$ & - & - & - & . & $\cdot$ \\
\hline$F-25$ & .12 .82 & 11.06 & 2.50 & 3.93 & 1.57 & 4.70 & 1.159 & - & 4.00 & 0.06 & 1.48 & 0.11 & 0.01 & 0.01 & 0.34 \\
\hline$F-26$ & 14.14 & 12.91 & 2.92 & 2.86 & 0.98 & 3.20 & 1.095 & - & 0.10 & 0.06 & 0.16 & 0.12 & 0.01 & 0.00 & 0.04 \\
\hline$F-27$ & 14.77 & 12.73 & 2.87 & 3.43 & 1.20 & 4.65 & 1.160 & - & 3.60 & 0.05 & 1.50 & 0.14 & 0.01 & 0.00 & 0.03 \\
\hline$F \cdot 28$ & 13.54 & 11.68 & 2.64 & 3.47 & 1.31 & 4.40 & 1.159 & - &. & $\cdot$ & - & - & - & - & - \\
\hline$F \cdot 29$ & 13.37 & 11.60 & 2.62 & 2.99 & 1.14 & 4.40 & 1.153 & - & . & - & - & - & - & - & - \\
\hline
\end{tabular}

(1) TOC - total organic carbon.

(2) To obtain mole carbonimole nitrogen natic, rultipl; C/NJ weight ratio by a factor $0=1$. 66 . 
Table 16

DENITRIFICATION CHEMICAL EQUATIONS

\begin{tabular}{|c|c|}
\hline & Methyl Alcohol(1) \\
\hline \multicolumn{2}{|c|}{$\mathrm{NO}_{3}^{-}+1.08 \mathrm{CH}_{3} \mathrm{OH}+\mathrm{H}^{+} \rightarrow 0.065 \mathrm{C}_{5} \mathrm{H}_{7} \mathrm{O}_{2} \mathrm{~N}+0.47 \mathrm{~N}_{2}+0.76 \mathrm{CO}_{2}+2.44 \mathrm{H}_{2} \mathrm{O}$} \\
\hline \multicolumn{2}{|c|}{$1.08 \mathrm{~mol}$ carbon to $1.0 \mathrm{~mol}$ nitrogen $=\mathrm{C} / \mathrm{N} \mathrm{mol} \mathrm{ratio} \mathrm{of} 1.08$} \\
\hline \multirow[t]{2}{*}{$12.96 \mathrm{~g}$ carbon to $14.0 \mathrm{~g}$ nitrogen } & $=\mathrm{C} / \mathrm{N}$ wt ratio of 0.93 \\
\hline & Calcium Acetate \\
\hline \multicolumn{2}{|c|}{$\begin{aligned} 0.65 \mathrm{Ca}\left(\mathrm{C}_{2} \mathrm{H}_{3} \mathrm{O}_{2}\right)_{2}+0.80 \mathrm{Ca}\left(\mathrm{NO}_{3}\right)_{2} \rightarrow & 0.12 \mathrm{C}_{5} \mathrm{H}_{7} \mathrm{O}_{2} \mathrm{~N}+0.55 \mathrm{CO}_{2}+0.74 \mathrm{~N}_{2}+1.45 \mathrm{CaCO}_{3} \\
& +1.35 \mathrm{~N}_{2} \mathrm{O}+0.36 \mathrm{OH}^{-}\end{aligned}$} \\
\hline \multicolumn{2}{|c|}{ 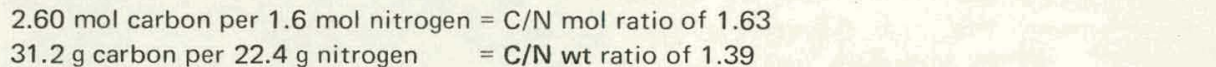 } \\
\hline $31.2 \mathrm{~g}$ carbon per $22.4 \mathrm{~g}$ nitrogen & $=\mathrm{C} / \mathrm{N}$ wt ratio of 1.39 \\
\hline
\end{tabular}

(1) From McCarty. (6)

\section{Identification of Active Bacteria}

Two bacterial cultures, obtained from the Biology Division of the Oak Ridge National Laboratory, were initially used in the laboratory studies. These seed cultures were identified by the names, "Pseudomonas stutzeri" and "Pseudomonas denitrificans". The Pseudomonas stutzeri culture was predominantly used as the original base seed culture. After activation of a $0.21 \mathrm{~m}^{3}$ (55-gal) drum, the culture was used whenever a new system was started. No identification was made of the types of bacteria present in the reactor solutions.

One sample was taken from an active reactor, and photomicrographs were obtained using optical microscopy, transmission electron microscopy (TEM), and scanning electron microscopy (SEM). For record purposes, typical photographs are presented in Figures 11 and 12.

The optical examination included: evaporation of a drop of the culture, heat fixation, and staining with the classical Gram's stair. The urganisms appeared as Gram negative bacilli. The SEMs were obtained by evaporation of the culture onto a glass cover slip and gold coating to provide electrical conductivity. TEM photographs involved dispensing the culture on collodion and staining with phosphotungstic acid to enhance contrast in the electron beam. Other than these examinations, no work was performed to identify or quantify the types and number of microbes.

\section{Mini I Reactor}

The first engineering version of a laboratory, stirred-bed reactor was a vessel having a liquid capacity of about $57 \mathrm{dm}^{3}$ and a free gas volume capacity of about $12 \mathrm{dm}^{3}$, as noted in Figure 9.

Reactor Feed Solutions - For the Mini I reactor tests, a synthetic feed was made using commerical-grade calcium nitratc and a chemically pure grade of calcium acetate (see discussion under Reactor Feeds, Page 28). In general, all feed solutions contained a nitrate level in the range of 10 to $13.5 \mathrm{wt} \%$ and the appropriate organic carbon level to obtain a 
nominal carbon-to-nitrogen mole ratio of 1.6. The $1.6 \mathrm{C} / \mathrm{N}$ ratio was decided upon to insure that an excess of organic carbon was present in the reactor.

Test Data - The first 50-day test was started on January 23, 1974 and terminated on March 12. The inlet flow to the system was controlled using a gravity-flow method and was not satisfactory. The unit was started without flow and was operated as a hatch-type operation for the tirst 14 days. Flow to the system was started on the 15th day and was stopped on the 41st day because of a high concentration of nitrate and nitrite ions in the reactor. The unit was operated nine additional days (to the 50th day) without flow. The nitrate level in the reactor decreased from 1.335 to 0.509 wt \% during this nine-day period. It was estimated that an additional 9 to 18-day waiting period would be required before the nitrate level was low enough to accept feed. The test was terminated to conserve time, and a new solution was added and labeled "Test 2".

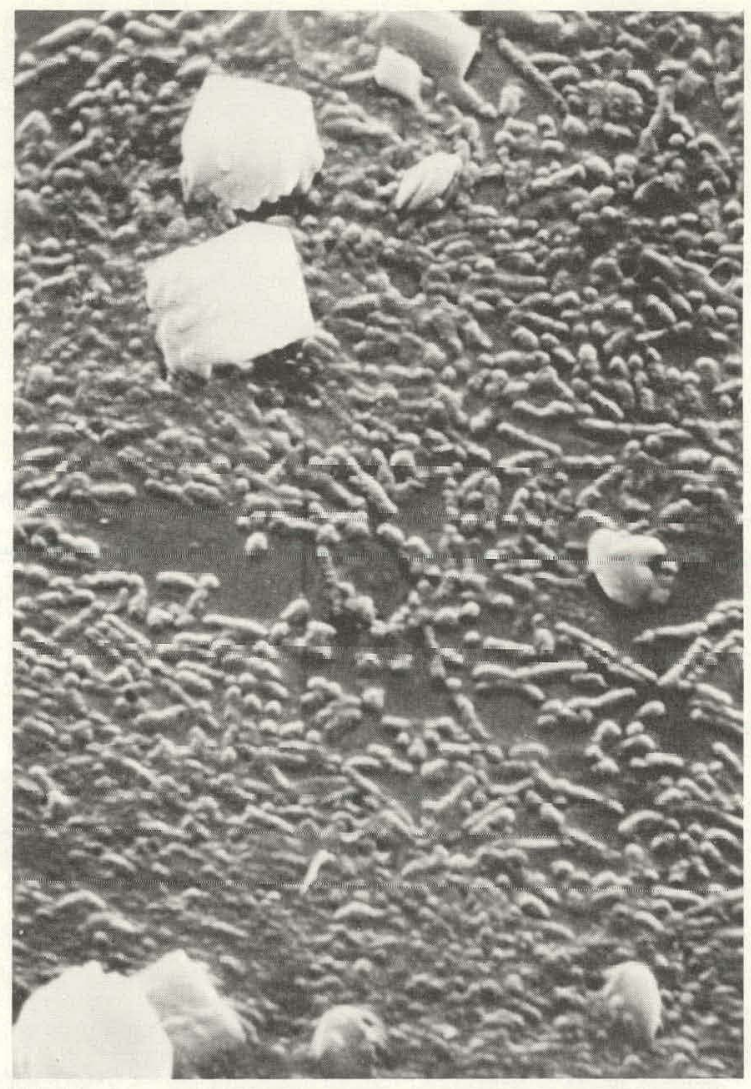

SM-42539

Figure 11. SCANNING ELECTRON MICROGRAPH OF NITRATE-ACTIVE BACIERIA. (3000 $\times)$

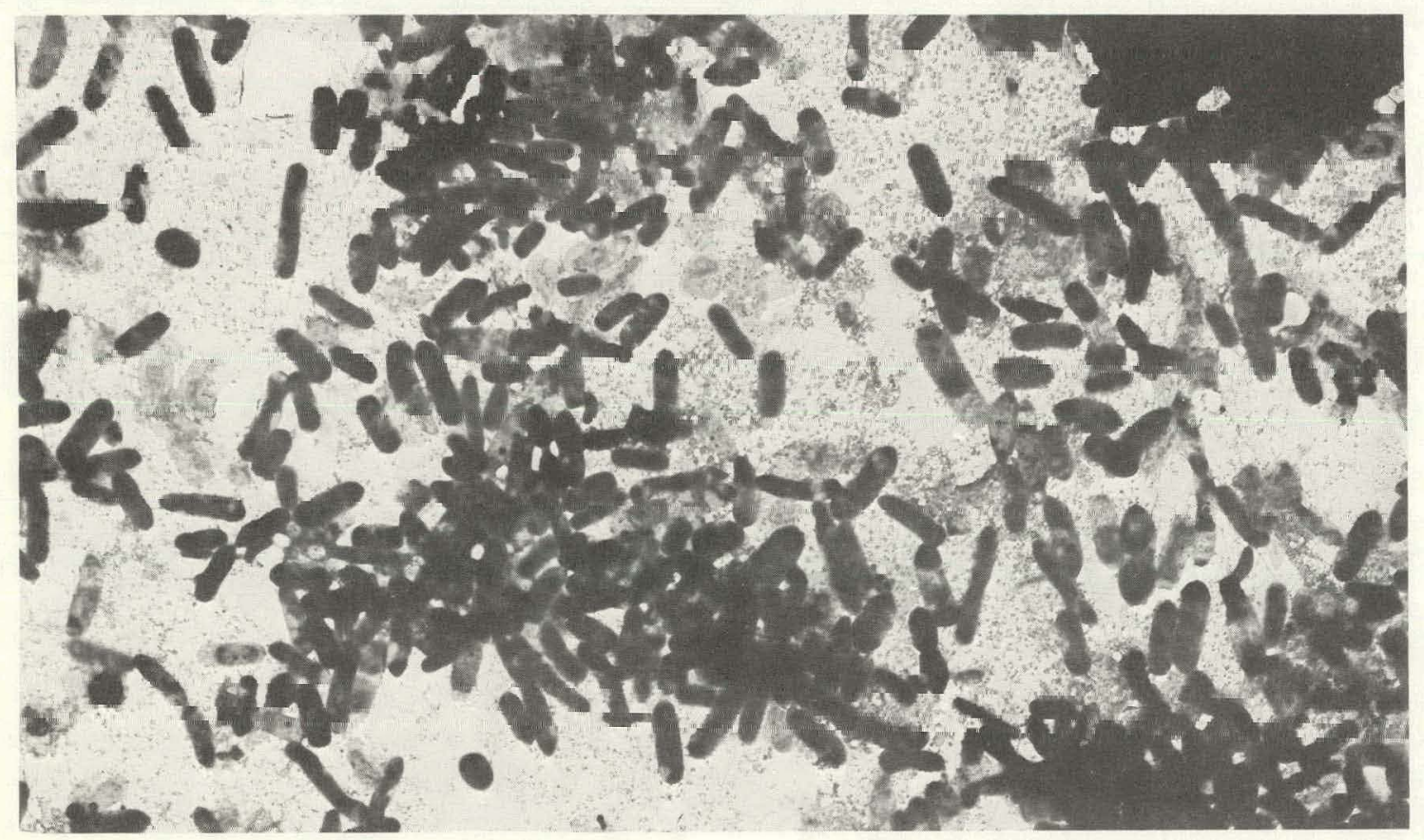

Figure 12. TRANSMISSION ELECTRON MICROGRAPH OF NITRATE-ACTIVE BACTERIA. (4800X) 
During the first test period, the nitrate feed rate was varied up to a maximum of $1.332 \mathrm{~kg}$ $\mathrm{NO}_{3}{ }^{-}$per day, which is equivalent to $23.4 \mathrm{~g} \mathrm{NO}_{3}^{-} /$day $/ \mathrm{dm}^{3}$ of reactor solution. The maximum feed rate of $1.332 \mathrm{~kg} \mathrm{NO}_{3}^{-}$per day caused the nitrate level in the tank to increase to an unreasonable level of $13,584 \mu \mathrm{g} / \mathrm{g}$. Sudden feed-rate increases were made over a time period of eight days, starting with Day 34 and ending at Day 41 . The system was not allowed to equilibrate after the flow increases occurred, and these sudden flow changes may have shocked the system.

Table A-1 (Appendix) is a tabulation of the experimental data which shows that the denitrification efficiency of converting the nitrate ion to nitrogen gas was usually above $98 \%$, except during the last nine days of the first test period.

The second test period was initiated on the 51st test day and extended through 135 test days. The nitrate feed rate to the reactor during this test period was held below $636 \mathrm{~g} \mathrm{NO}_{3}^{-}$ per day, which is equivalent to $11.16 \mathrm{~g} \mathrm{NO}_{3}^{-} / \mathrm{dm}^{3} /$ day solution in the reactor. The reactor efficiency was a nominal $99.8 \%$ except for nine test days when the efficiency dropped to a low of $96.2 \%$ (Table A-1).

During this 84-day test period, the feed to the reactor was stopped four times for a total of nine days to allow the nitrate concentration in the reactor to decrease to an acceptable level (less than $500 \mu \mathrm{g} / \mathrm{g}$ nitrate). The cause of the four perturbations in this test period is not known. The first upset occurred on Day 83, and the feed was stopped for one day. The nitrate ion level in the reactor had increased from less than 100 to a level of $4143 \mu \mathrm{g} / \mathrm{g}$, the nitrite ion increased from less than 5 to $1030 \mu \mathrm{g} / \mathrm{g}$, and the total organic carbon (TOC) level increased to $3450 \mu \mathrm{g} / \mathrm{g}$. The carbon-to-nitrogen mole ratio in the reactor at this time was 2.76. In general, the carbon-to-nitrogen mole ratio in the reactor during satisfactory operations was greater than 20, but less than 100 .

The second perturbation occurred on Day 117, and the feed was stopped for two days. The nitrate ion level in the reactor increased from a nominal 126 to $462 \mu \mathrm{g} / \mathrm{g}$. At this time, the TOC level was a nominal $4050 \mu \mathrm{g} / \mathrm{g}$, and the $\mathrm{C} / \mathrm{N}$ mole ratio was 144 , which is considered to be too high for satisfactory operation.

The third perturbation occurred on Day 130, and the flow was stopped for two days. The nitrate ion level in the reactor had increased to $1330 \mu \mathrm{g} / \mathrm{g}$, the nitrite ion level had increased to $374 \mu \mathrm{g} / \mathrm{g}$, and the TOC level was $1525 \mu \mathrm{g} / \mathrm{g}$. The $\mathrm{C} / \mathrm{N}$ mole ratio at this time was 3.69 , which was below the desired operating range of 20 to 100 .

The fourth upset occurred on Day 132 and is believed to be as a result of startirig the reactor flow without adjusting the low $\mathrm{C} / \mathrm{N}$ mole rativ.

Analytical Data - Analytical data on the effluent from the Mini I reactor are reported in Table A-2, Appendix. In all cases, the reported analyses were made on clear solutions obtained by centrifuging and filtering through a micrn filter. Later samples were centrifuged using an ultra-high-speed centrifuge instead of a low-speed centrifuge. Analytical data were also occasionally obtained on as-taken samples, and the nitrate level usually was in agreement with the centrifuge/filter data. The TOC levels were decreased by the centrifuge/filtration of the samples. 
Gas Analysis - Data on the gaseous products from the reactor are presented in Table A-3. The total gas volume was obtained by passing all of the gases through a wet-test flow meter. The amount of gas evolved per hour, reported in Table A-3, was normally an average of the overnight (16-hour) gas production and was used in an effort to minimize the effects of sample-withdrawal operations which normally occurred during the day.

The carbon dioxide content of the evolved gascs was determined by standard gas chromatographic techniques using a sample injected into the instrument. Heriodlcally, tho instrument was calibrated using a gas mixture containing a known amount of carbon dioxide and nitrogen gases. Also, occasional gas samples were analyzed using mass spectrographic techniques.

The nitrugeir gas volıme. noted in Takle A.3, was calculated us the difference between the amounts of carbon dioxide and the total gas volume. The nili ugen calculation is bolieverd to be valid, based on the analysis obtained from the mass spectrographic data. I race inipurities in the gas of a normal functioning reactor consisted of argon and oxygen which was always less than a total of $1 \%$. During abnormal operations, nitric oxide gas was generally present, and the level could be as high as $13 \%$. The gas chromatograph instrument used for this study detected both nitrogen oxide and carbon dioxide gases as only carbon dioxide. In all cases when the carbon dioxide level, noted in Table A-1, was above $55 \%$, and if nitric oxide gas were also present, the reactor was found to be operating at an unsatisfactory level.

Total Organic Carbon Data - Early analytical TOC data were obtained on "settled" samples from the reactor. About Day 50, the TOC data (Table A-2) were obtained by using low-speed centrifuged and filtered samples. Low-speed centrifuge techniques did not produce a "clear" or biomass-fiee sample. Centrifuged solutions were then filtered through a 0.33-micrometer-pore-sized paper filter to obtain a "clear" and biumass free snlution. Later analyses were obtained using an ultra-high-speed centrifuge followed by filtration through a micro pore filler. TOC values thus obtained were lower, and the difference between thesc TOC values and the previous lower-speed centrifuged and filtnred samples appears to have been due to biomass or insoluble organic constituents in the solutions.

Ammonium lon - Analylical data on the ammonium inn concentration in the reactor is presented in Table A-2. The ammonilum ion was present in lhe synthetir feed solution which has previously been discussed in the Reactor Feeds section of this repuit. The conrentration increased in the reactor to a nominal $4500 \mu \mathrm{g} / \mathrm{g}$, which was approximately the level in the feed solution. This level of ammonium ion caused no detectable adverse effects on the reactur pcrfuimance. A nominal 30 days were requircd for the ammonium ion to increase from a level of 300 to $4500 \mu \mathrm{g} / \mathrm{g}$.

Phosphate - A nominal $20 \mu \mathrm{g} / \mathrm{g}$ of phosphate was routinely added on a once-per-day batch basis to the rcuctor and was added as a potassium phosphate solution. Phosphate analyses, given in Table A-2, indicate that less than $5 \mu \mathrm{g} / \mathrm{g}$ of snluble phosphate was present in the reactor solution. The low phosphate level was caused by the low solubility of the phosphate ion in the reactor solution. Excess phosphates probably precipitated from the solution as calcium phosphate solid. In any event, the daily addition of soluble phosphate ions was required. When this ion was not added, the reactor efficiency was always adversely affected because phosphates are a required nutrient for the reproduction of microbes. 
Hydrogen Ion Measurements - A radical change in the $\mathrm{pH}$ of the reactor solution will act as a shock to the denitrifying bacteria. In the anaerobic denitrification reaction, which is highly buffered by carbonate and bicarbonate ions, and with an excess of $\mathrm{CO}_{2}$ gas present, the $\mathrm{pH}$ of the solution seeks and maintains its unique level. The $\mathrm{pH}$ of a normal working reactor lies between 6.5 and 7.6 , with an average value of 6.8 .

Temperature - The temperature of the reactor solution inside the reactor was typically 2 to $5^{\circ} \mathrm{C}$ above ambient temperatures and was dependent on the denitrification rate.

\section{Mini II Reactor}

Design of the Mini II reactor was the same as Mini I except that the liquid volume was increased to $67.2 \mathrm{dm}^{3}$. The free-gas-volume capacity remained at about $12 \mathrm{dm}^{3}$. The vessel was equipped the same as Mini I, and the same measurements were routinely made.

Reactor Feed Solutions - The reactor tests were started on April 2, 1974, using a solution containing an inoculum from a batch reactor. Approximately 25 vol \% of the "seed" solution and $75 \mathrm{vol} \%$ water were added to the vessel. The starting nitrate level was approximately $250 \mu \mathrm{g} / \mathrm{g}$. Approximately a month was required before denitrification occurred at a reasonable rate. The vessel was periodically batch-fed nitrate and organic carbon solutions during this acclimation period. On the 31st test day, continuous feed to the vessel was started using a solution of commerical-grade calcium nitrate and sufficient calcium acetate solution to obtain a carbon-to-nitrogen mole ratio of 1.3. After four days of operation (Day $35)$, the feed solution was changed to nitric acid-raffinate wastes from the production plant. The organic carbon source and the carbon-to-nitrogen mole ratio were not significantly changed.

Test Data - As previously stated, a batch-type operation was conducted during the first 30 days of the test., with feed occasionally introduced into the reactor. During this period, the stirring motor failed and other equipment problems were resolved. The reactor was started on continuous feed on the 31st test day using a commerical grade of calcium acetate. After four days (Table A-4), the nitrate feed was changed to nitric acid-raffinate wastes from the Y-12 Plant. The acid wastes were mixed directly with the calcium acetate solution. As previously stated, it was assumed that the acid solution would be neutralized by the calcium bicarbonate ions and carbonate solids in the reactor solution. This operational change eliminated the need for a neutralization step; therefore, a significant amount of capital equipment was cancelled in the design of the plant.

After two satisfactory operating days (Day 37), the inlet feed valve to the reactor failed and a large volume of acid feed was suddenly dumped into the reactor. The $\mathrm{pH}$ of the reactor solution immediately droppen from 6.4 to 3.9, and the nitrate level in the reactor increased from 53 to $12,000 \mu \mathrm{g} / \mathrm{g}$ (Table A-4). A water slurry of calciurn hydroxide was added to the reactor to adjust the $\mathrm{pH}$ to a nominal value of 6.2 . For the next 12 days, a pH level of 5.8 to 6.4 was maintained by additions of calcium hydroxide. This operational procedure appeared to minimize the "shock" effect to the reactor, and continuous feed was again started after a 12-day delay (Day 50). During the first four days of the 12-day offstream time, the nitrate level decreased from $12,000 \mu \mathrm{g} / \mathrm{g}$ to less than $200 \mu \mathrm{g} / \mathrm{g}$ (Day 42). Feed was not restarted until Day 50 in order to redesign the feed system. A mechanical pump was installed in the feed system to provide a "fail safe" feed condition. 
Continuous feed flow was administered successfully until Day 80. At this time, half of the reacto, solution was taken from the Mini $1 /$ reactor and used to activate a new reactor (Mini IV). Water was added to the Mini II reactor to refill the vessel. The feed rate was decreased from 4.80 to $0.93 \mathrm{~g} \mathrm{NO}_{3}^{-} /$day $/ \mathrm{dm}^{3}$ of reactor solution, then progressively increased over the next eight days to the level of $4.4 \mathrm{~g} \mathrm{NO}_{3}^{-} /$day $/ \mathrm{dm}^{3}$ of reactor solution. There was no evidence that the reactor performance was affected by this procedure.

During the next 64-day period, feed-flow variations ranged from 1 to $9 \mathrm{~g} \mathrm{NO}_{3}-/$ day $/ \mathrm{dm}^{3}$ of reactor solution. The feed was cut off on Day 114 and restarted on Day 124. The nitrate level in the reactor had increased from a nominal $60 \mu \mathrm{g} / \mathrm{g}$ (Day 112) to $2445 \mu \mathrm{g} / \mathrm{g}$ (Day 113). On Day 114, the nitrate level had decreased to $1562 \mu \mathrm{g} / \mathrm{g}$ and the feed flow was stopped to allow the level to decrease to below $100 \mu \mathrm{g} / \mathrm{g}$, which occurred on Day 123 . The cause of the increased nitrate level is not known, but the feed flow to the reactor had been doubled on Day 108. This sudden flow increase may have caused a "shock" to the reactor. In any case, the reactor returned to normal operational conditions within 10 days.

As previously stated, the feed was resumed on Day 124 at a level of three grams of nitiale per day per $\mathrm{dm}^{3}$ of reactor solution. This feed level was mairlaained tor five days (Day 125) and then the flow was abruptly increased to nine grams of nitrate per day per $\mathrm{dm}^{3}$ uf reactor solution (Day 130). The higher flow rate was about equal to the flow rate which was present when abnormal operations occurred on Day 114. There were no obvious adverse effects observed after the feed flow was increased. The reactor test was terminated on Day 133 in order to use the reactor vessel for other biological studies.

Analytical Data - Analytical data of the effluent from the reactor are summarized in Table A-5. In all cases, the reported analyses were made on "clear" solutions obtained by centrifugation and filtration of the solution. These data show that the effluent from the rear.tor was normally less than $200 \mu \mathrm{g} / \mathrm{g}$, and the TOC level was more than 300 , but less than $3800 \mu \mathrm{g} / \mathrm{g}$. The nitrate concentration was normally not detectable except during abnormal operating conditions (Table A-5). As notcd in Table A-5, the phosphate level was always less than $5 \mu \mathrm{g} / \mathrm{g}$, which was the detectable level of the analytical procedure. The ammonium ion concentration, reported in Table $\mathrm{A}-5$, was a result of feeding commerical-grade calcium nillate which contained a nominal $4.8 \%$ by weight of ammonium nitrate. Ammonium nitrate contaminant was nol normally present in the nitric acid-raffinate feed from the uranium purification proress.

Gas Analysis - Gas analyses trom the reastor gaseous effluent are presentco in Table A-6. In gerieral, the carbon dioxide concentration in the offgases was a nominal 38 wt \% when using curimercial-grade calcium nituatc foed, and a nominal 58 wt \% when using nilric acid-raffinate feeds. Carbon dioxide was higher with the acid foens hecause the acid was neutralized in the reactor with excess calcium salts, and curbon dioxide was liberated by this reaction. A significarit change in the carbon dioxide concentration was always an indicatnr of abnormal operating conditions. Also, a change in the gas evolution rate was an indicator of reactor prublemis. In general, the total gas evolved in a normal operating reactor using nitric acid-raffinate feed was $0.450 \mathrm{dm} 3 / \mathrm{g}$ nitrute feed to the reactor.

Total Organic Carbon Data - As noted in Table A-5, the TOC level in the reactor ranged from 900 to $3800 \mu \mathrm{g} / \mathrm{g}$. The majority of the reactor test days were run at TOC levels ranging from 900 to $2000 \mu \mathrm{g} / \mathrm{g}$. 
Hydrogen Ion Measurements - The Mini $1 /$ reactor operated at a $\mathrm{pH}$ range of 6.6 to 7.3 . Normally, a $\mathrm{pH}$ of 6.8 was noted in the reactor solution.

Phosphates - The phosphate level in the reactor was consistently less than $5 \mu \mathrm{g} / \mathrm{g}$, which was the analytical detectable level (Table A-6).

Temperature - The reactor operated between 21 and $31^{\circ} \mathrm{C}$. Typically, the solution was 2 to $5^{\circ} \mathrm{C}$ above ambient temperature and always increased with increased feed rates.

\section{Mini III Reactor}

Mini $1 / 1$ reactor design was a duplicate of the Mini 11 reactor and was operated in order to determine if the performance of the Mini 11 reactor could be duplicated. It was also intended to study higher feed rates in this reactor.

Reactor Feed Solutions - Most of the nitrate feed solutions to this reactor were from the nitric acid-raffinate waste stream from the uranium purification plant. Feeds $F-13$ through F-24 (Table 15) were used, starting on the 56th test day and ending on the 198th test day.

Reactor Test Data - The Mini Ill reactor was started as a batch operation. Continuous flow was started on the 24th test day (Table A-7). A nominal flow of $2 \mathrm{~g} \mathrm{NO}_{3}^{-} / \mathrm{day} / \mathrm{dm}^{3}$ of reactor solution was maintained from the 24 th to the 35th test day (11 days), then the flow was doubled to a nominal $4 \mathrm{~g} \mathrm{NO}_{3}^{-} /$day/dm 3 of reactor solution. Reactor operating data, including feed flow rates, are noted in Figure 13. On the 40th test day, the feed valve failed and the reactor vessel was quickly filled with nitric acid-raffinate solution. Consequently, the nitrate level in the vessel increased to more than 4 wt \%. Calcium hydroxide was added to adjust the $\mathrm{pH}$ of the solution and the feed was stopped. On the 48 th test day, the reactor solution was discarded and replaced with a viable solution from an existing batch test. Continuous feed to the reactor was started on Day 50 at a nitrate feed rate of $2.2 \mathrm{~g} \mathrm{NO}_{3}^{-} /$day $/ \mathrm{dm}^{3}$ of reactor solution. Flow was then slowly increased up to a nominal $9 \mathrm{~g} \mathrm{NO}_{3}^{-} / \mathrm{day} / \mathrm{dm}^{3}$ (Figure 13). On Day 112, the flow was stopped for a 48-hour period because the nitrate level in the tank had suddenly increased from a nominal less than $300 \mu \mathrm{g} / \mathrm{g}$ to $10,528 \mu \mathrm{g} / \mathrm{g}$ (Table A-8). TOC in the reactor had reached a level of $4366^{\circ} \mu \mathrm{g} / \mathrm{g}$ on Day 108. On Day 112, the TOC level had increased to $6450 \mu \mathrm{g} / \mathrm{g}$, which was significantly higher than the normal operating TOC level of 2000 to $3000 \mu \mathrm{g} / \mathrm{g}$.

After the flow was stopped on Day 112, the nitrate and TOC concentrations in the reactor dropped to $289 \mu \mathrm{g} / \mathrm{g} \mathrm{NO}_{3}{ }^{-}$and $4010 \mu \mathrm{g} / \mathrm{g}$ TOC on Day 114. Flow was resumed on Day 114 at a nominal $1.47 \mathrm{~g} \mathrm{NO}_{3}^{-} /$day $/ \mathrm{dm}^{3}$ of reactor solution and was increased to a nominal $7 \mathrm{y}$ $\mathrm{NO}_{3}{ }^{-} /$day $/ \mathrm{dm}^{3}$ on Day 120 (Figure 13). On Day 122, llow was stopped for a 24-hour period to allnw the nitidte concentration in the reactor to decrease from a nominal 5600 to $90 \mu \mathrm{g} / \mathrm{g}$. TOC concentration was approximately $4500 \mu \mathrm{g} / \mathrm{g}$, and additional carbon was added which may not have been needed.

Flow was restarted on Day 123 and continued until Day 171. During this test period, the TOC concentration in the tank was reduced from a nominal $4500 \mu \mathrm{g} / \mathrm{g}$ to a low of $370 \mu \mathrm{g} / \mathrm{g}$ by adding feed solutions which were deficient in organic carbou. On Uay 170 , the nitrate concentration in the reactor increased to $3447 \mu \mathrm{g} / \mathrm{y}$ with a TOC concentration of $1820 \mu \mathrm{g} / \mathrm{g}$ 


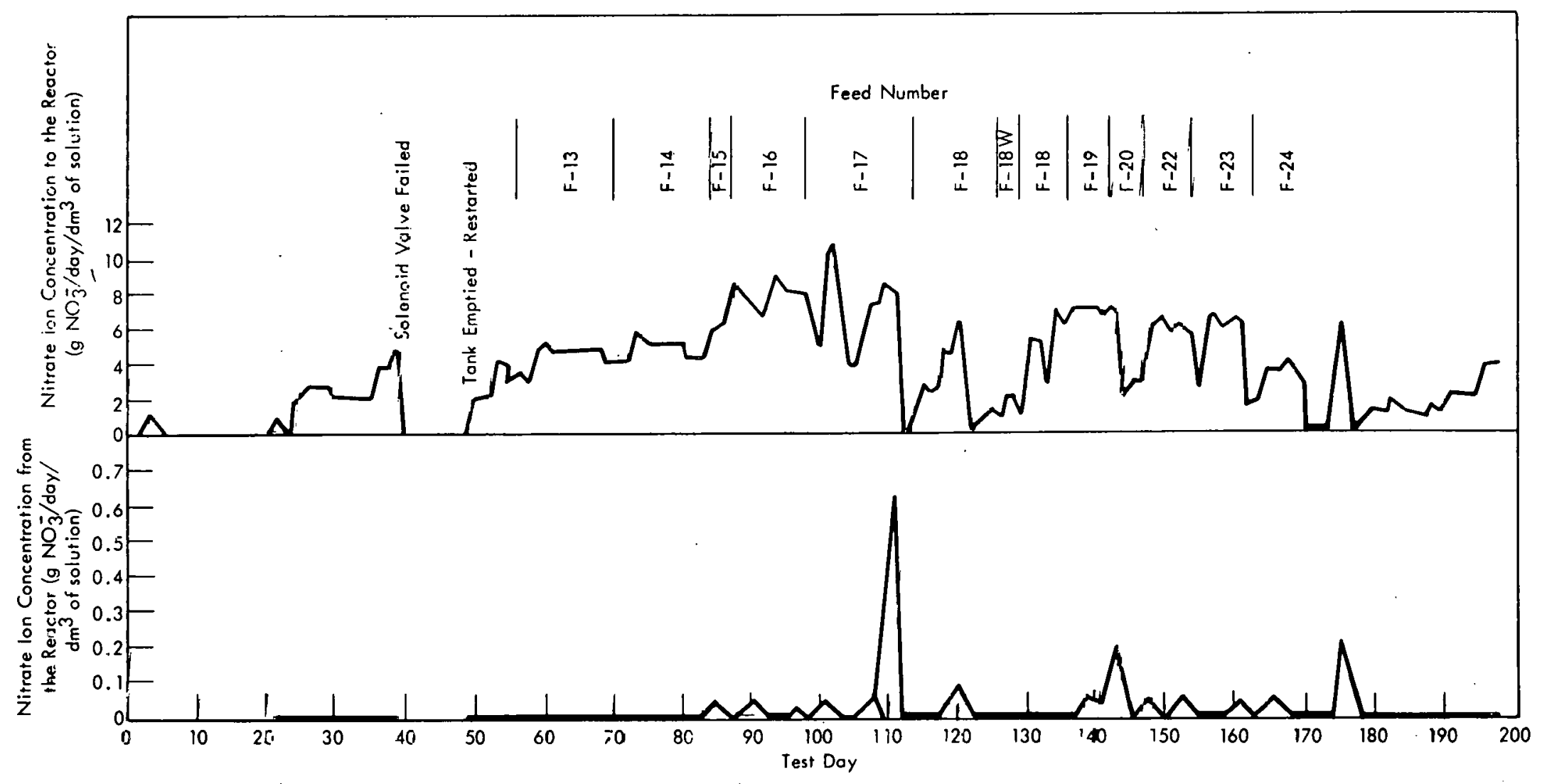

Figure 13. AMOUNT OF NITRATE REDUCED IN THE MINI III REACTDF. 
(Table A-8). Flow was restarted on Day 174 when the nitrate level had decreased to 121 $\mu \mathrm{g} / \mathrm{g}$ and the TOC concentration was $1170 \mu \mathrm{g} / \mathrm{g}$.

The feed flow, noted in Figure 13 and Table A-7, was continued at a high flow rate from Day 174 to Day 176 . The nitrate concentration in the reactor again increased to $4381 \mu \mathrm{g} / \mathrm{g}$ and the feed flow was again stopped for a 24-hour recovery period. Flow was restarted on Day 178 and continued through Day 200 with satisfactory operation.

Analytical Data - Analytical data on the liquid discharge from the Mini III reactor are given in Table A-8. These data show that the reactor normally operated at a nitrate effluent concentration of less than $200 \mu \mathrm{g} / \mathrm{g}$. Nitrite ions were only present when the reactor was not operating properly.

Total Organic Carbon Data - The reactor solution contained a wide variation in the organic carbon, as noted in Table A-8 and Figure 14. These data show that the TOC concentration consistently varied during the 200-day test period. The last 60 days of the test had a TOC concentration span ranging from a low of 400 to a high of $2000 \mu \mathrm{g} / \mathrm{g}$. The TOC level in the reactor was dependent on the carbon-to-nitrogen weight ratio in the inlet feed, which is tabulated in Figure 14. The optimum carbon-to-nitrogen weight ratio in the inlet feed was not established during the 200-day test period. A "best-estimate" carbon-tu-nitrogen weight ratio of 1.10 to 1.20 appears to be a ratio which would maintain a near constant level of organic carbon in the reactor.

During the last 60 days of the test period, a few chemical analyses were made to determine both the acetate carbon and the TOC in the reactor solution. The available data are reported in Table 17. These data show that the difference

Table 17

ACETATE CARBON AND TOTAL. ORGANIC CARBON CONCENTRATIONS

\begin{tabular}{|c|c|c|c|}
\hline $\begin{array}{l}\text { Test } \\
\text { (day) } \\
\end{array}$ & $\begin{array}{c}\text { Total Organic } \\
\text { Carbon } \\
(\mu \mathrm{g} / \mathrm{g})\end{array}$ & $\begin{array}{c}\text { Acetate } \\
\text { Carbon } \\
(\mu \mathrm{g} / \mathrm{g})\end{array}$ & $\begin{array}{c}\text { Difference } \\
(\mu \mathrm{g} / \mathrm{g})\end{array}$ \\
\hline 136 & 1905 & 1275 & 630 \\
\hline 140 & 630 & yo & 540 \\
\hline 141 & 650 & 30 & 620 \\
\hline 142 & 380 & $<25$ & 355 \\
\hline $146^{\circ}$ & 675 & 283 & 392 \\
\hline 147 & 535 & 156 & 379 \\
\hline 148 & 555 & 13 & 542 \\
\hline 154 & 370 & 7 & 363 \\
\hline \multicolumn{3}{|c|}{ Average Concentration Difference } & 545 \\
\hline
\end{tabular}
between the TOC and the acetate carbon is an average value of $545 \mu \mathrm{g} / \mathrm{g}$ lower. In other words, when the TOC concentration approaches a value of $545 \mu \mathrm{g} / \mathrm{g}$, there is no acetate carbon available for denitrification. During the Mini III test period, low TOC values were observed beginning at about :Day 140 and extending through Day 160. Extra acetate carbon was added six times, as noted in Table A-8, in order to keep the reactor operating at a satisfactory rate.

Gas Analysis - Available gas analyses from the Mini III reactor operation are presented in Table A.9 and Figure 15. The carbon dioxide level normally was in the range of 50 to $60 \mathrm{vol} \%$ in the offgases. When the $\mathrm{CO}_{2}$ content was above 60 vol \% (which occurred 11 times during the 200-day test neriod), the reactor solution contained a nitrate concentration of more than $300 \mu \mathrm{g} / \mathrm{g}$ and was not operating satisfactorily.

Exclusive of the first 60 days of test, the average amount of carbon dioxide generated in the reactor was $0.2379 \mathrm{dm}^{3}$ of $\mathrm{CO}_{2}$ per gram of nitrate decomposed in the reactor. The average total gas volume from the reactor, exclusive of the first 60 days of test, was $0.4478 \mathrm{dm}^{3}$ per gram of nitrate decomposed in the reactor. 


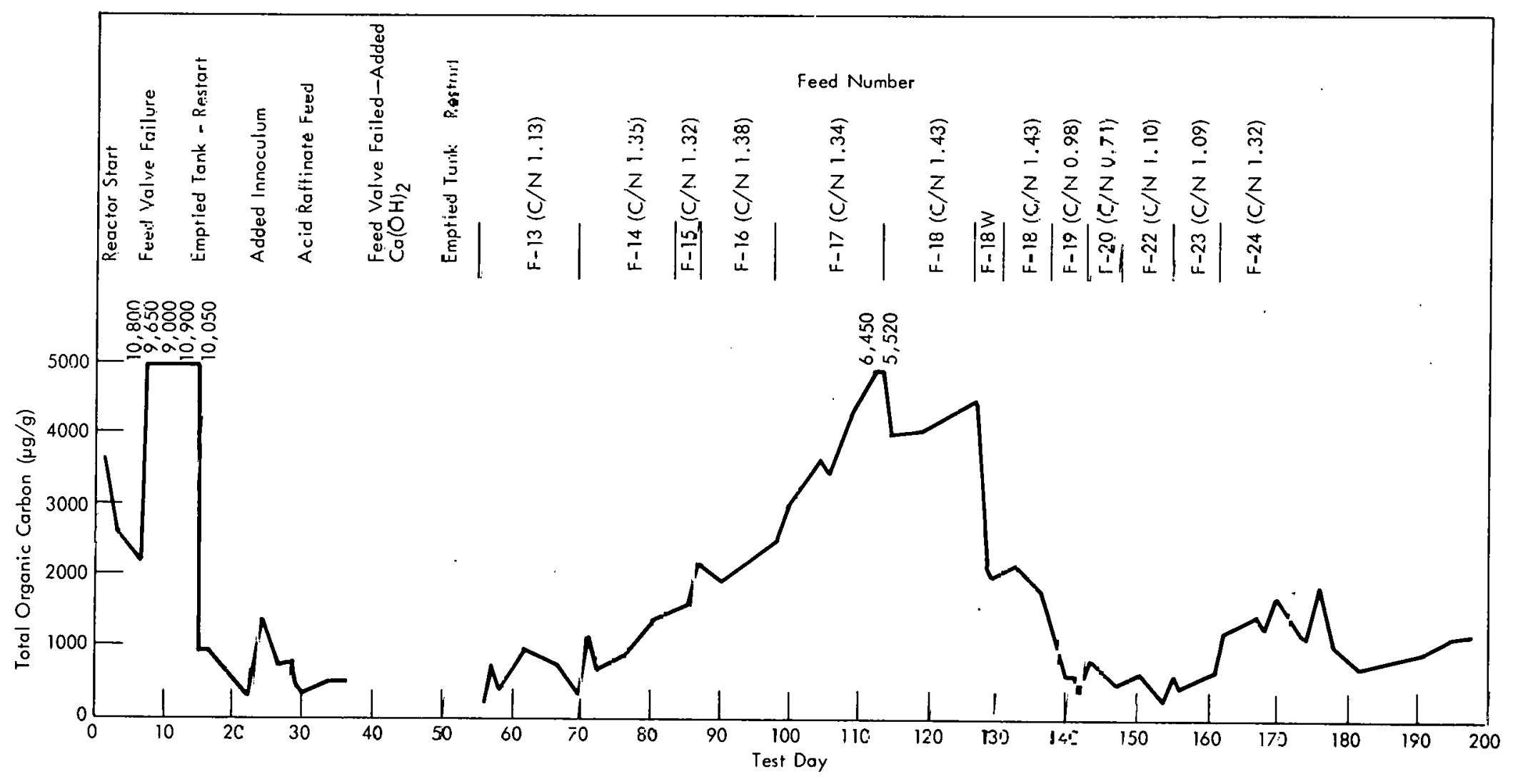

Figu:e 14. TOTAL ORGAN'C. CAREON CONCENTRATION IN THE MINI III, REECTOR. 


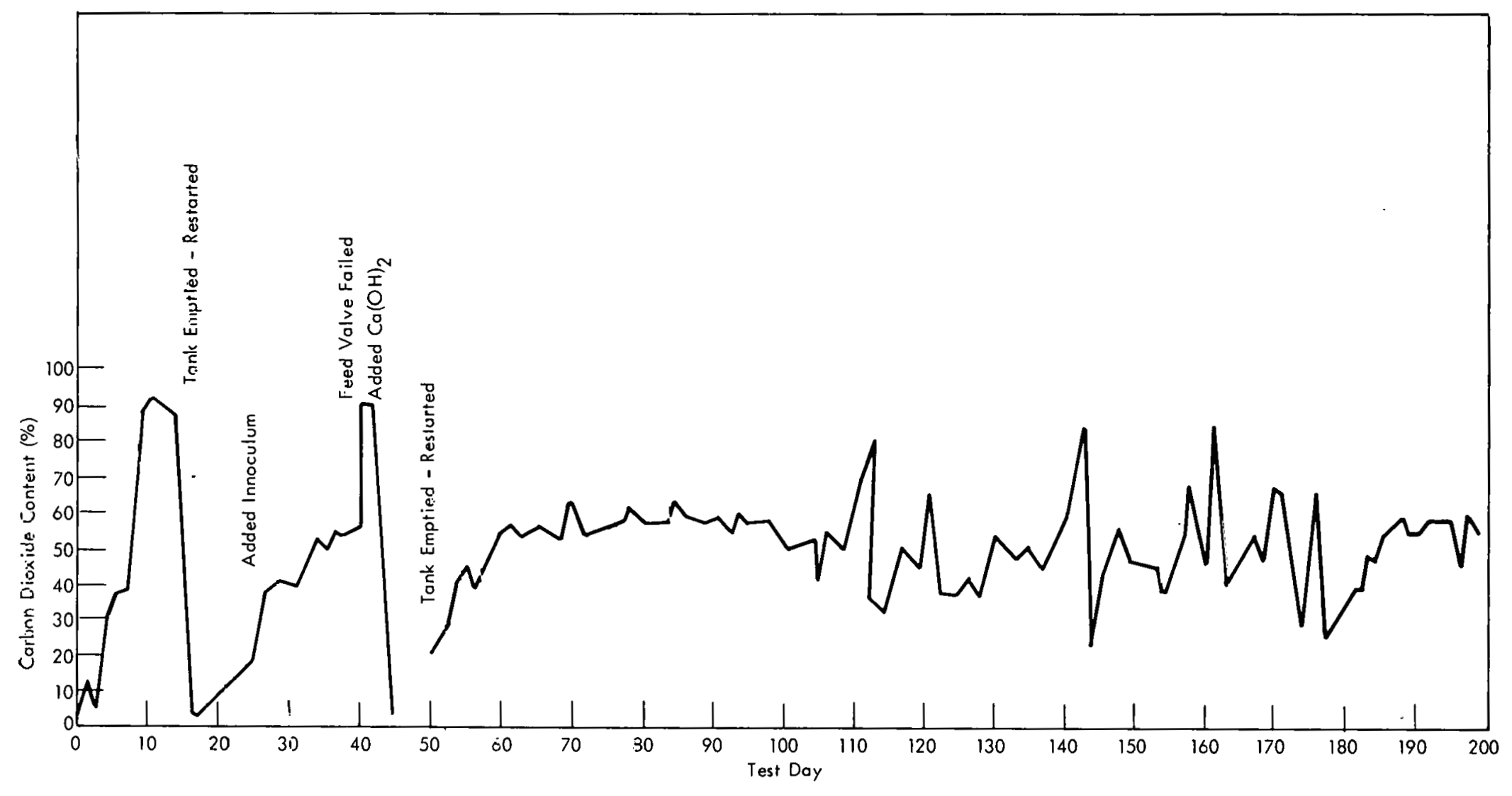

Figure 15. CAREON DIOXIDE CONCENTRATION OF THE EFFLUENT GAS FROM MINI III. 
Hydrogen Ion Measurement - The $\mathrm{pH}$ of the reactor normally ranged from 6.7 to 7.3 , with a typical value of 7.0 .

The lower limit of total organic carbon in the reactor appcars to be near $600 \mu \mathrm{g} / \mathrm{g}$. At this level, the acetate carbon concentration is normally less than $100 \mu \mathrm{g} / \mathrm{g}$, and there is not a sufficient supply of carbon available for the denitrification reaction.

\section{Mini IV Reactor}

The Mini IV reactor was designed to permit removal of solids from the side of the reactor (Figure 10). A sedimentation "pocket" was constructed inside the reactor where the solids could settle and be removed from the pocket through a drain pipe arrangement. This solid-withdraval mothor worked very satisfactorily, and this Mini IV design was selected for the scaled-up denitrification vessels for the ' $Y$ '-12 Plant installation.

Reactor Feed Solutions - Feed solutions used during this lest period ranged from Batches F-13 through F-23 (Table 15). The operating time periods for each of the feed solutions are also noted (Figure 16). In all cases, the carbon-to-nitrogen weight ratio of the feeds ranged from 0.71 to 1.43 . In some cases, additional carbon was added on a batch basis when using low carbon feeds $(\mathrm{C} / \mathrm{N}$ weight ratio $<1.0)$.

Reactor Test Data - The reactor was inoculated on June 19, 1974 by transferring an active biological solution from the Mini I reactor. Continuous feed flow was started on June 20. Daily nitrate feed rates are reported in Figure 16 and Table A-10. The reactor operated for a total test period of 134 dayys.

The first 35-day test pcriod showed normal operations, with the effluent from the reactor containing less than $200 \mu \mathrm{g} / \mathrm{g}$ nitrate ion (Table A-11 and Figure 16). High nitrate levels in the redactor were delected uil tho 36 th dav, so the feed rate was decreased trom a nominal six grams of nitrate per day per dri, 3 of reactor sulution lo nne gram. The teed rate was again increased, starting with Day 41. Pump.plugging problems occurred about Day 47 inl equipment repairs were made. The feed flows were again increased to six grams of nitrate per day per $\mathrm{dm}^{3}$ of reactor solution. High niliatcs were detectable in the reactor on Days $71,72,79$, and 80 . Consequently, the foed flnw was reduced on Day 81 iu a nominal $1 \mathrm{~g}$ $\mathrm{NO}_{3}-/$ day/dm ${ }^{3}$, but again raised the next day. A high nitrate level was again retected in the reactor on Days 97, 107, 108, 113, and 119. In each case, high nitrate levels decreased 10 less than $200 \mu \mathrm{g} / \mathrm{y}$ nitrate with in 24 hours.

Analytical Data-Analytical data on the liquid effluent from the Mini IV Ieactor are reported in Table A-11. These data show that the reactor operated for 114 days out of the. 134 test days at a nitrate discharge level of loss than $400 \mu \mathrm{g} / \mathrm{g}$.

Total Organic Carbon Data - The TOC level in the reactor varied over a wide range, as noted in Table A-11 and Figure 17. The TOC level was dependent on the $\mathrm{C} / \mathrm{N}$ weight ratio in the feed solution; and, in general, a TOC range of 1000 to $4000 \mu \mathrm{g} / \mathrm{g}$ produced a satisfactory denitrification rate. A few analyses were also made to determine both the TOC and the acetate carbon levels. The available data are given in Table 18. The acetate carbon 

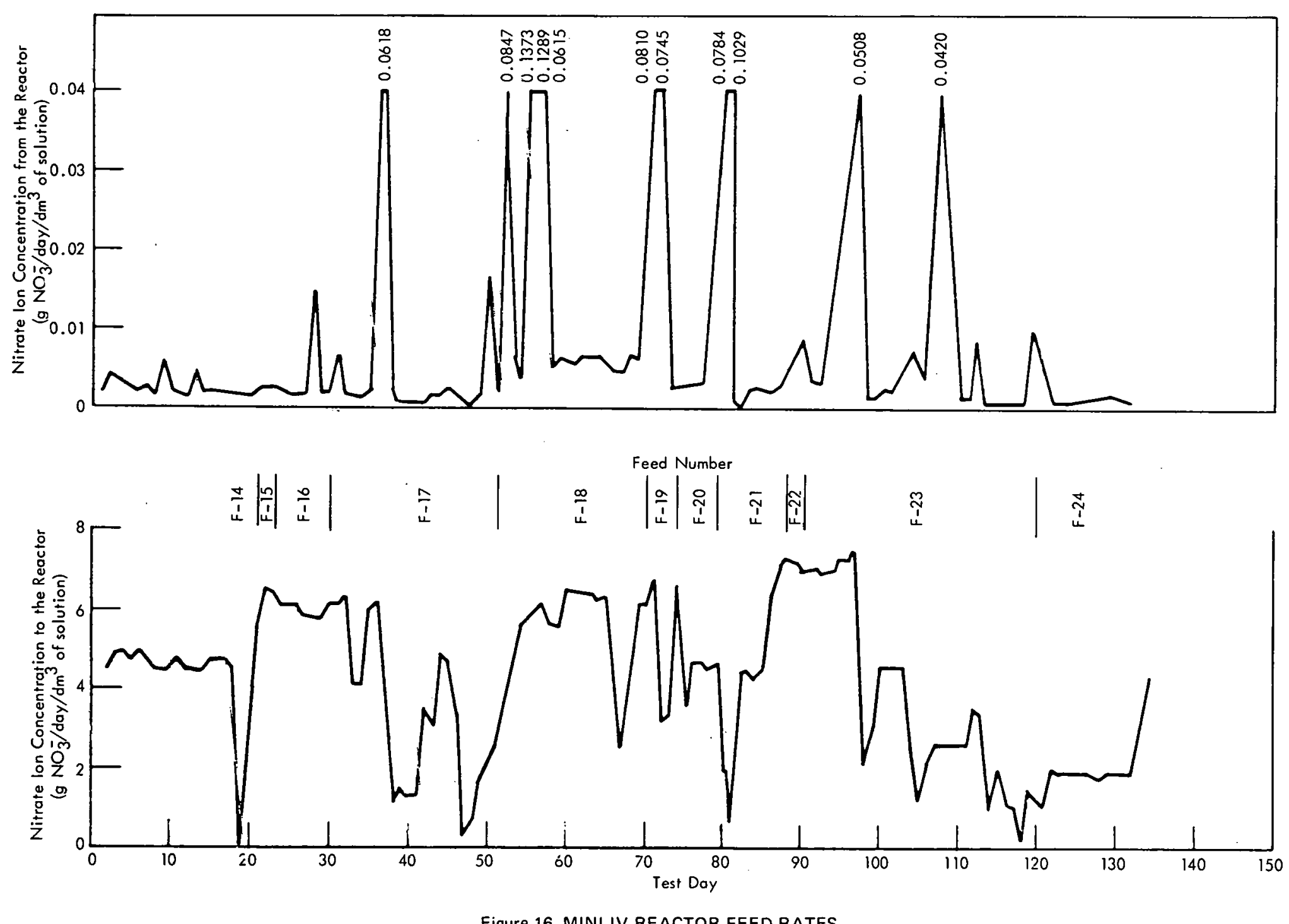


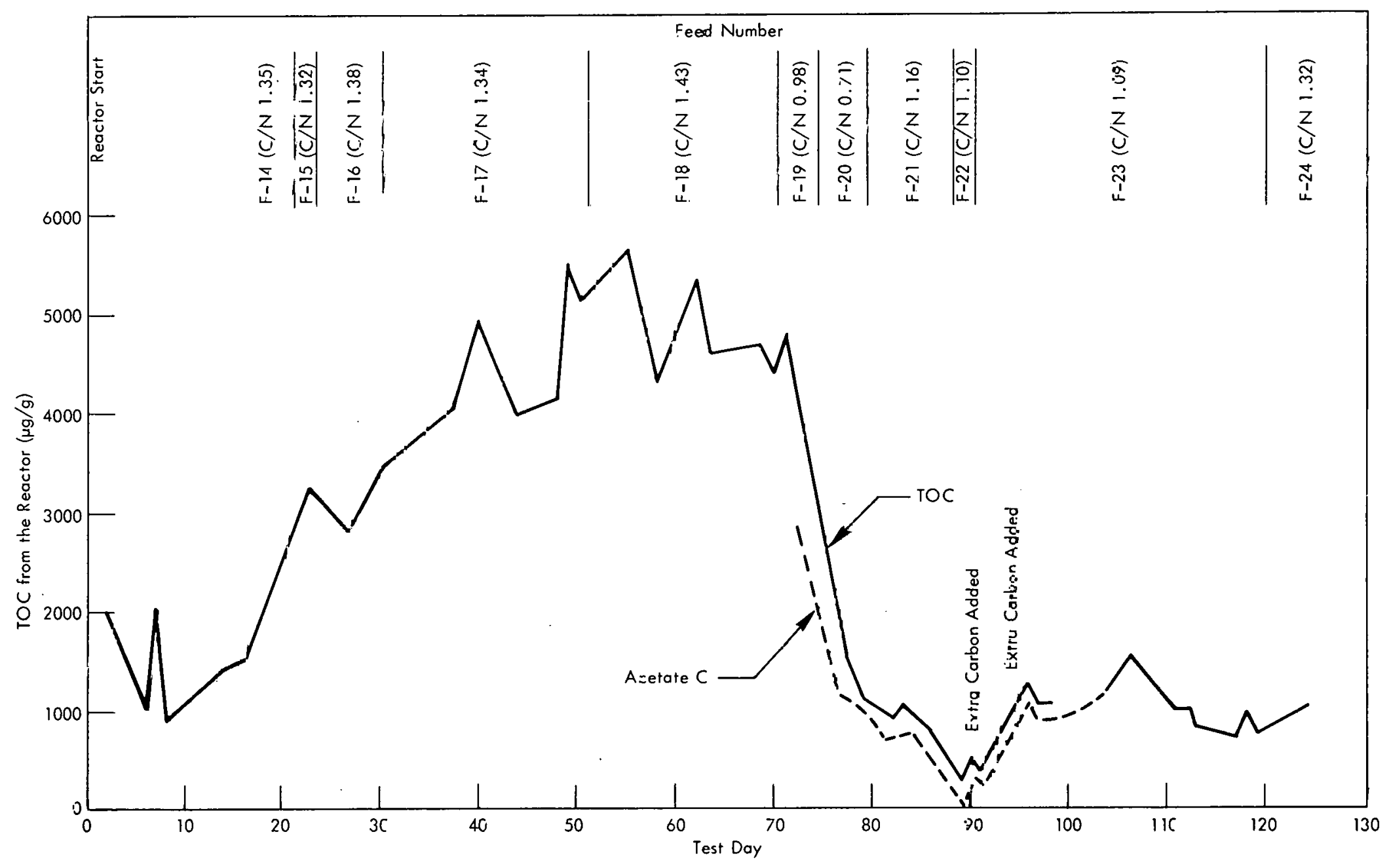

Figure 17. TOTAL ORGANIC CARBON CONCENTRATION IN THE MINI IY F.EACTOR. 
concentration was usually 10 to $33 \%$ less than the TOC values. A brief review of the TOC data shows that the TOC concentration progressively increased from the starting date of the reactor until about Day 50. At this point, the TOC level remained at about the 5000 $\mu \mathrm{g} / \mathrm{g}$ level until Day 70. A decrease in the TOC concentration occurred by adding feeds containing a low $\mathrm{C} / \mathrm{N}$ weight ratio. The TOC was allowed to decrease to a nominal 240 $\mu \mathrm{g} / \mathrm{g}$, which occurred on Day 90 . The TOC concentration was then increased to a nominal $1000 \mu \mathrm{g} / \mathrm{g}$, where it remained at approximately this level until Day 135.

Hydrogen Ion Measurement - The $\mathrm{pH}$ of the Mini IV reactor has remained in the range of 6.6 to 7.3 .

Temperature - The temperature of the reactor remained in the range of 20 to $30^{\circ} \mathrm{C}$, and normally was 1 to $4^{\circ} \mathrm{C}$ higher than the ambient temperature.

Gas Composition-Gas flows and the gas composition from the Mini IV reactor are tabulated in Table A-12. As revealed hy thesc data, an average of $0.486 \mathrm{dm}^{3}$ of gas per gram of decomposed nitrate was generated in the reactor. The reactor released an average of $52.6 \%$ carbon dioxide, which is equivalent to $0.256 \mathrm{dm}^{3}$ of $\mathrm{CO}_{2}$ gas per gram of nitrate decomposed. As was noted with the other reactors, the reactor performance could be observed by monitoring the $\mathrm{CO}_{2}$ level in the effluent gas. If levels above $60 \%$ were noted, a high concentration of nitrate was always found in the effluent from the reactor.

\section{Removal of Solids}

Solids were routinely taken from thc reaclurs in an attempt to establish a material balance around the reactors. As noted in Table 19, a daily average of 2242 grams of feed solution was added to both the Mini II and Mini III reactors. The total flow of liquid and solids from these reactors had an average dally weight of 2694 grams. The higher weight of material from the reactor can be partially explained by the fact that a riuminal 100 grams of a solution of water and trace nutrients containing phosphate ions were added daily to the reactors.

A calculated material balance, based on the data listed in Tables 19 and 20, indicates that about $45 \%$ of the calcium is removed daily in the effluent. The aluminum from Mini II showed that $126 \%$ of this element was rernoved daily; and, from Mini II, a nominal $60 \%$ of the alumirum was removed, for a combined average value of $93.2 \%$. The high aluminum 
Table 19,

M.ATERIAL BALANCE D.ATA FO 7 THE FOUR REACTORS

\begin{tabular}{|c|c|c|c|c|c|c|}
\hline \multirow[b]{2}{*}{ Reactor } & \multicolumn{2}{|c|}{ Daily Average Fied to the Reactor } & \multicolumn{3}{|c|}{ Cail. Average Withdrawal from the Reactors (g) } & \multirow{2}{*}{$\begin{array}{c}\text { Grams of Dry } \\
\text { Solids per Grem } \\
\text { of Nitrate }\end{array}$} \\
\hline & $\left(\mathrm{NO}_{3}{ }^{-} /\right.$day $)$ & (gliq/day) & Solids and Water & Filtered Cake & Dry Cake & \\
\hline Mini II & 333.6 & 2242 & 2629 & 1307 & 275 & 0.82 \\
\hline Mini III & 247.0 & 2243 & 2760 & 1190 & $17: 3$ & 0.72 \\
\hline
\end{tabular}

Chemical Analysis of the Feed Solution

\begin{tabular}{|c|c|c|c|c|c|c|c|c|c|c|c|c|c|}
\hline \multirow[b]{2}{*}{ Feed } & \multirow{2}{*}{$\begin{array}{c}\text { Uranium } \\
\text { Content } \\
(\mu \mathrm{g} / \mathrm{g})\end{array}$} & \multirow{2}{*}{$\begin{array}{c}\text { Total } \\
\text { N'itrate } \\
(\%)\end{array}$} & \multirow{2}{*}{$\begin{array}{l}\text { Specific } \\
\text { Gravity }\end{array}$} & \multicolumn{10}{|c|}{ Impurity Content (\%) } \\
\hline & & & & Al & $\mathrm{Ca}$ & $\mathrm{Mg}$ & $\mathrm{Cu}$ & $\mathrm{Fe}$ & $\mathrm{Na}$ & $\alpha$ & $\mathrm{Li}$ & $\mathrm{CO}_{2}$ & Organic Carbon \\
\hline 12 & $<0.04$ & 14.13 & 1.163 & 0.92 & 3.47 & 0.27 & 0.001 & 0.11 & 0.035 & & 0.006 & - & $\cdot$ \\
\hline 13 & $<0.04$ & 13.88 & - & 0.94 & 3.54 & 0.27 & 0.001 & 0.12 & 0.034 & - & 0.007 & - & - \\
\hline 14 & $\cdot$ & 13.70 & 1160 & 1.26 & 3.56 & 0.04 & - & 0.03 & 0.11 & $a 007$ & 0.006 & - & - \\
\hline Average & $<0.04$ & 13.90 & $1.16 i$ & 104 & 3.52 & 0.19 & 0.001 & 0.09 & 0.06 & $C . C \subset$ & 0.006 & . & - \\
\hline
\end{tabular}

Chemical A רa.ysis of the Disch arge from :he Reactors (dried solids in the effluent)

\begin{tabular}{|c|c|c|c|c|c|c|c|c|c|c|}
\hline \multirow[b]{2}{*}{ Reactor } & \multicolumn{10}{|c|}{ Impurity Content (\%) } \\
\hline & $\mathrm{Ca}$ & $\mathrm{Mg}$ & Al & $\mathrm{Fe}$ & $P$ & $\mathrm{Na}$ & $\bar{K}$ & $-i$ & $\mathrm{CO}_{2}$ & Organic Carbon \\
\hline Mini $\mid 1(1)$ & 13.63 & 0.55 & 10.67 & 0.62 & - & 0.17 & - & 0.016 & 19.89 & 7.56 \\
\hline Mini $I I I(2)$ & 13.68 & 0.57 & 10.14 & 0.59 & . & 0.16 & - & 0.015 & 21.14 & 6.23 \\
\hline Mini $11(3)$ & 14.90 & 0.50 & 9.38 & 0.58 & - & 0.14 & - & 0.02 & 21.56 & 6.49 \\
\hline Mini III (3) & 19.53 & 2.44 & 7.31 & 0.06 & 0.28 & 0.04 & 0.30 & 0.02 & - & . \\
\hline Mini IV(3) & 16.97 & 2.91 & 8.54 & 0.06 & 0.38 & 0.06 & 0.53 & c. 04 & - & - \\
\hline
\end{tabular}

Solution from the Reactor after Filtration

\begin{tabular}{|c|c|c|c|c|c|c|c|c|}
\hline \multirow[b]{2}{*}{ Reactor } & \multicolumn{8}{|c|}{ Impurity Content (\%) } \\
\hline & Total $\mathrm{NO}_{3}^{-}$ & Al & $\mathrm{Ca}$ & $\mathrm{Mg}$ & $\mathrm{Na}$ & $F$ & $\mathrm{Li}$ & Organic Carbon \\
\hline Mini IV & 0.017 & $<0.01$ & 0.04 & 0.30 & 0.02 & 2.04 & 0.01 & 0.43 \\
\hline
\end{tabular}

(1) Dried solids taken from the bo:-:om of the reactor.

(2) Dried solids taken from the :eactor solution.

(3) Dried solids taken from the overflom stream. 
value from Mini II cannot be explained since it was impossible to remove this amount of aluminum based on the available chemical analysis data.

Solids were deposited inside of the reactor vessel; and, after a nominal 100-day test, the vessels were opened for inspection. The chemical composition of these solids, given in Table 19, was equivalent to the solids removed in the discharge stream, which was expected. The amount of solids deposited in the reactor was not exactly determined, but an approximate weight per day indicated that the amount of solids in the reactor after the 100-day tests was equal to the amount which was leaving the reactor. The amount of solids to be deposited in the plantsized unit cannot be estimated from the laboratory studies since the plant unit will not have the same surface area-toliquid volume ratio as the laboratory unit.

\section{PILOT-PLANT STIRRED- BED REACTOR STUDIES}

\section{Introduction}

Due to the success of the laboratory stirred-bed reactors, a $15 \mathrm{~m}^{3}$ vessel was modified to serve as a pilot plant. A schematic diagram and a photographis. viow of the system are provided in Figures 18 and 19. Feeds to the pilot plant consisted, initially, of neutralized slurries of the nitrate acidic wastes from the plant. Later studies used nitric acid and acidified aluminum nitrate (AAN).

Initially, the pilot plant was operated on a batch basis (from August through October 1973). After some equipment modifications, continuous-flow studies were conducted (from February to August 1974). In order for a facility to be attractive, it must demonstrate a capability for continuous operation, have minimum equipment failures, and be relatively free from toxic effects induced by abrupt changes in the feed composition, $\mathrm{pH}$, 
temperature, or other unknown effects. This section of the report describes the operation of the continuous-flow, stirred-bed pilot-plant reactor.

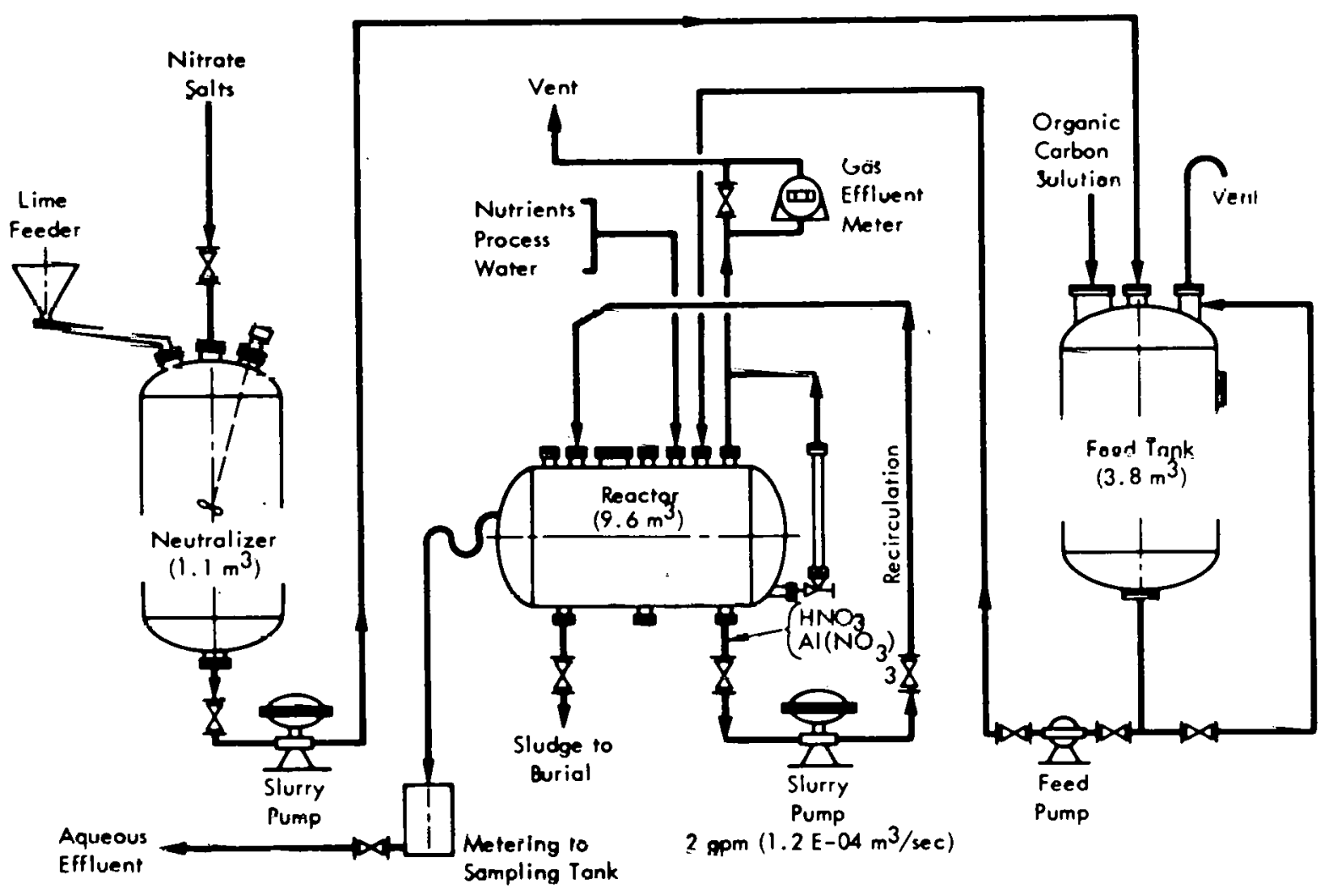

Figure 18. PMINCIPAL COMRONENTS IN THE DIODFNITRIFICATION PILOT PLANT.

\section{Experimental Work}

Batch Operation of the Pilot Plant - Eight batch-type experimental biodenitrification runs were successfully completer in the pilot-plant facility over a three-month operating period (August through October 1973). Individual Latch operatıons varlied from 4 to 22 days in duration, depending on the operating conditiuns. Reaction kinetics was depondent on a number of parameters such as: feed ratcs, cell-growth rates, nutrient concentrations and ratıos, drid variations in temperature and $\mathrm{pH}$. Varying degrees of biological shock can occur in the systom if any of these parameters are abruptly or drastically changed.

Data from a typical biodenitrification pilot plant run are given in Table 21. The fees material used in this batch run was Y-12 Plant evaporator condensate neutralized with lime hydrate and supplied as calcium acetate solution and trisodium phosphate. Daily nitrate ion, total carbori, and TOC concentrations are noted in Table 21. Curves showing progressive carbon-to-nitrogen ratios $(C / N)$ versus the percent nitrate reduction and a plot of daily temperature variations with nitrate reduction rates are given in Figures 20 and 21.

Lime hydrate-neutralized solution was difficult to prepare in the available neutralization equipment, particularly when plant raffinate effluents were neutralized. The gel-like 


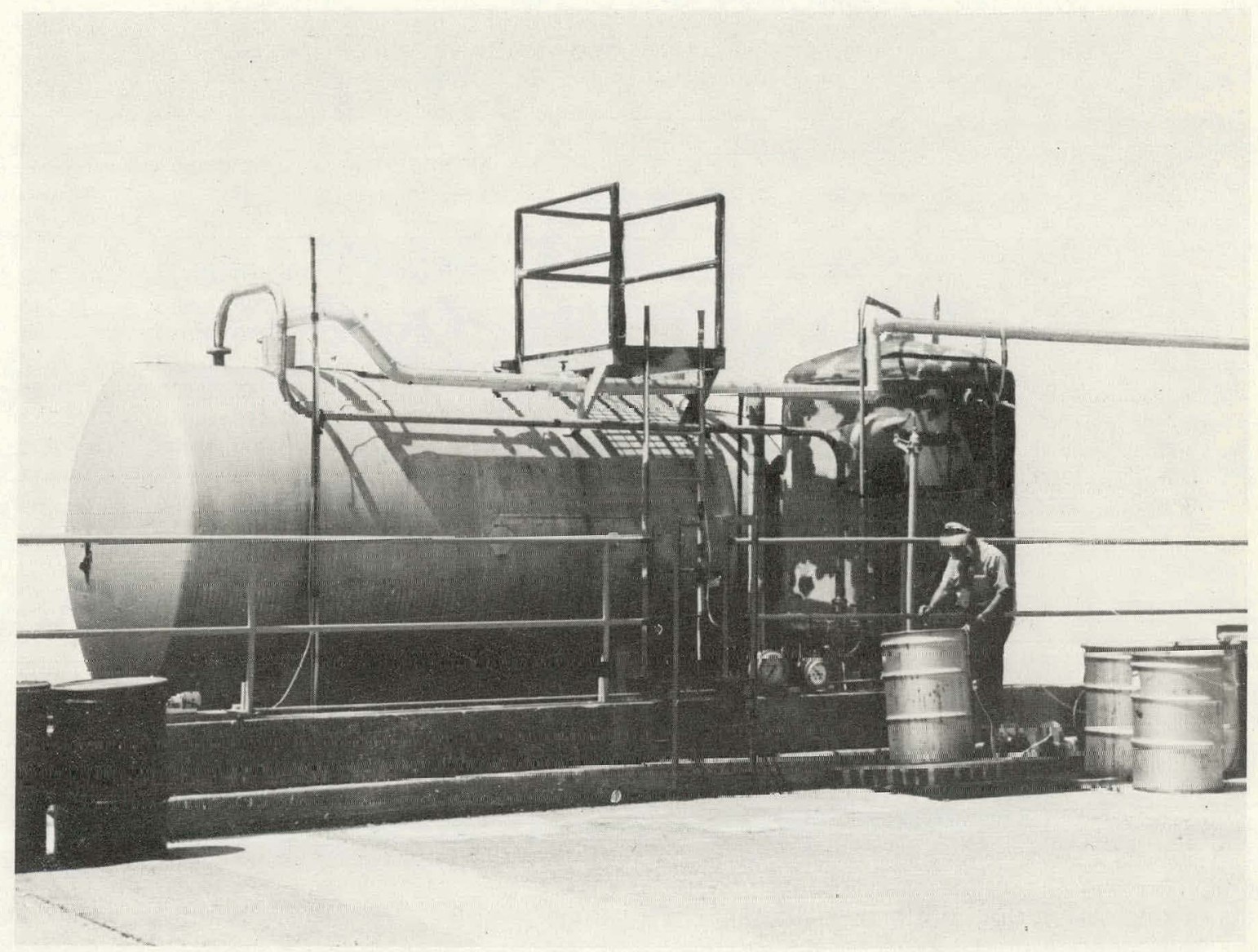

Figure 19. BIODENITRIFICATION PILUT-PLANT FACILITY.

precipitate was a heterogeneous, sticky, and lumpy mass that was difficult to convert to a homogeneous, free-flowing slurry without vigorous agitation or excessive dilution.

Because of the difficulties associated with lime hydrate neutralization of raffinates, flake sodium hydroxide was dissovled in water and added to a 1:1 solution of water and raffinate. Neutralization with sodium hydroxide was far less complicated and formed a slurry that was more readily pumped than the lime hydrate slurries. Also, the final carbonate effluent solution could be readily pumped back to the neutralization tank for reuse, if desired. Tests showed, however, that the calcite sludge produced in the reactor could be used equally as well to ncutralize raffinate whlien properly slurried. Later, experimental tests also indicated that raw condensates and raffinates could be pumped directly into the reactor, there being sufficient hydroxide and carbonate ions in solution with calcite in the reactor to effect neutralization. This procedure was followed in subsequent continuous operations with injections of $70 \%$ nitric acid or acidified aluminum nitrate.

Results from a batch run using flake sodium hydroxide to neutralize raffinate are presented in Table 2? In comparing the two runs, many similarilies are evident; however, there was a significant reduction in the carbon-to-nitrogen ratio $(\mathrm{C} / \mathrm{N})$ which was $0.8: 1$ for the sodium hydroxide batches versus a $\mathrm{C} / \mathrm{N}$ of 1.11:1 for the lime hydrate-neu tralized batches. 
Table 21

PILOT-PLANT OPERATING CONDITIONS AND PERFORMANCE

(Run 4; Tank Volume, 14,440 $\mathrm{dm}^{3}$ )

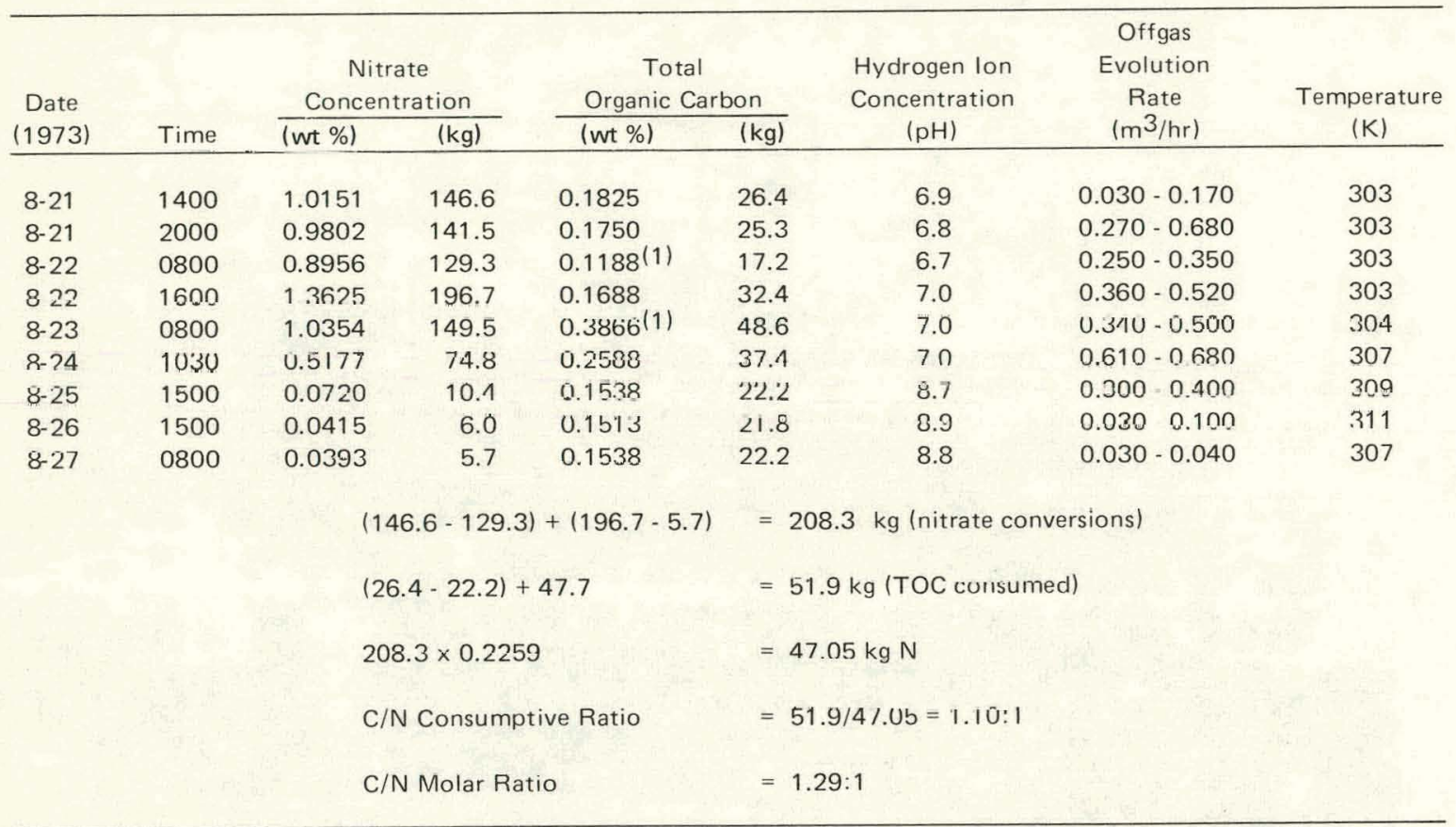

(1) Net addition, $47.7 \mathrm{~kg}$.

X-ray diffraction patterns of composited sludge samples removed from the bottom of the suspended-bed reactor (Table 23) indicated that the major constitutent in the dry sludge was calcite $\left(\mathrm{CaCO}_{3}\right)$ with a hexagonal crystal structure. These composites uf naturally thickened sludges contained residues from six batch runs using lime hydrate and one batch run using sodium hydroxide for neutralization.

No X-ray pattern for $\mathrm{Na}_{2} \mathrm{CO}_{3}$ was detected, due to its solubility. Aluminum, which was one of the major chemical components in the spectrographic analysis (Table 23), did not show

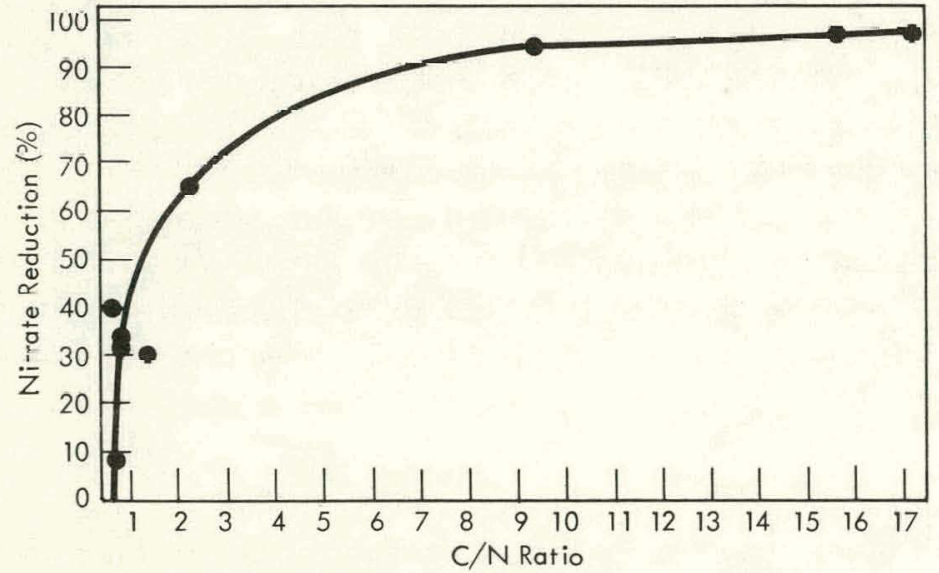

Figure 20. PROGRESSIVE DENITRIFICATION VERSUS THE CARBON-TO-NITROGEN RATIOS. in the X-ray pattern due to the amorphous nature of aluminum hydrate. Moisture determinations on this settled sludge after two weeks and decanting excess water indicated that the sludge contained $36 \%$ solids. Spectrochemical analyses (Table 23 ) of the two composite dry residue samples are very similar in composition, with calcium, aluminum, and carbon predominating. Lesser quantities of iron, potassium, magnesium, sodium, phosphorus, and silicon (which are classified as micronutrients), 
as well as uranium, were present. X-ray diffraction patterns of an aqueous effluent sample, slowly evaporated to dryness at room temperature, showed the major constitutents to be orthorhombic sodium carbonate $\left(\mathrm{Na}_{2} \mathrm{CO}_{3} \cdot \mathrm{H}_{2} \mathrm{O}\right)$, and monoclinic sodium bicarbonate complexed with sodium carbonate $\left(\mathrm{NaHCO}_{3} \cdot \mathrm{Na}_{2} \mathrm{CO}_{3} \cdot 2 \mathrm{H}_{2} \mathrm{O}\right)$. An intermediate $X$-ray pattern was identified as monoclinic sodium carbonate and potassium hydrogen malate monohydrate $\left(\mathrm{KHC}_{4} \mathrm{H}_{4} \mathrm{O}_{5} \cdot \mathrm{H}_{2} \mathrm{O}\right)$, identified as a minor constituent.

In batch operations, the $\mathrm{pH}$ usually remains close to 7.0 during high denitrification periods when carbon dioxide evolution is at a maximum and the reactor is buffered by an excess of the bicarbonate ion. When evolution of $\mathrm{CO}_{2}$ diminishes, the $\mathrm{pH}$ increases because of an excess of the hydroxyl ion. Above a pH of 8.3, the carbonate ion usually prevails and precipitation of calcium carbonate occurs. There appears to be some interaction between calcium carbonate precipitation and dispersed colloidal alumirium hydroxide particles. This interaction results in coagulation of the dispersed particles into aggolomerates which settle more rapidly, giving relatively clear

Table 22

PILOT-PLANT OPERATING CONDITIONS AND PERFORMANCE (Run 7; Tank Volume, 13, $490 \mathrm{dm}^{3}$ )

\begin{tabular}{|c|c|c|c|c|c|c|c|}
\hline \multirow{3}{*}{$\begin{array}{c}\text { Date } \\
(1973) \\
\end{array}$} & \multirow{2}{*}{\multicolumn{2}{|c|}{$\begin{array}{c}\text { Nitrate } \\
\text { Concentration }\end{array}$}} & \multirow{2}{*}{\multicolumn{2}{|c|}{$\begin{array}{c}\text { Total } \\
\text { Organic Carbon }\end{array}$}} & \multirow{3}{*}{$\begin{array}{c}\text { Hydrogen Ion } \\
\text { Concentration } \\
(\mathrm{pH})\end{array}$} & \multirow{3}{*}{$\begin{array}{c}\text { Offges } \\
\text { Evulution } \\
\text { Rate } \\
\left(\mathrm{m}^{3} / \mathrm{hr}\right) \\
\end{array}$} & \multirow{3}{*}{$\begin{array}{c}\text { Temperature } \\
\text { (K) }\end{array}$} \\
\hline & & & & & & & \\
\hline & (wt \%) & $(\mathrm{kg})$ & (wt \%) & $(\mathrm{kg})$ & & & \\
\hline $10-6$ & 1.4326 & 193.3 & 0.4125 & 55.6 & 7.5 & $0.090-0.100$ & 303 \\
\hline $10-7$ & 1.2745 & 171.9 & 0.3675 & 49.6 & 6.8 & $0.160-0.240$ & 305 \\
\hline $10-8$ & 0.6970 & 94.0 & 0.3250 & 43.8 & 7.4 & $0.350-0.570$ & 311 \\
\hline $10-9$ & 0.1085 & 14.6 & 0.2200 & 29.7 & 8.9 & $0.325-0.400$ & 307 \\
\hline \multirow[t]{6}{*}{$10-10$} & 0.0205 & 2.8 & 0.1625 & 21.9 & 10.8 & $0.020-0.060$ & 301 \\
\hline & \multicolumn{4}{|c|}{$193.3 \cdot 2.8$} & \multicolumn{2}{|c|}{$=190.5 \mathrm{~kg}$ (nitratc converted) } & \\
\hline & \multicolumn{4}{|c|}{$55.6 \cdot 21.9$} & \multicolumn{2}{|c|}{$=33.7 \mathrm{~kg}$ (TOC consumed) } & \\
\hline & \multicolumn{4}{|c|}{$190.5 \times 0.2259$} & \multicolumn{2}{|l|}{$=43.0 \mathrm{~kg} \mathrm{~N}$} & \\
\hline & \multicolumn{6}{|c|}{$\mathrm{C} / \mathrm{N}$ Consumptive Ratio $=33.7 / 43.0=0.784: 1$} & \\
\hline & \multicolumn{4}{|c|}{ C/N Molar Ratio } & \multicolumn{2}{|l|}{$=0.91: 1$} & \\
\hline
\end{tabular}

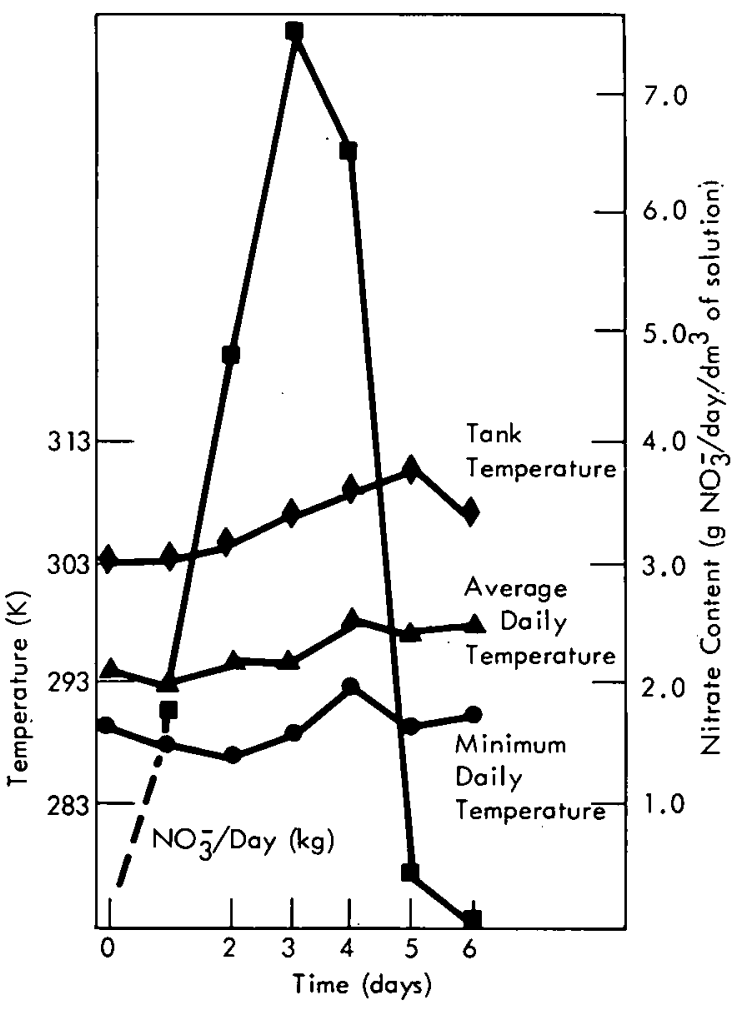

Figure 21. DAILY TEMPERATURE VARIATIONS AND PILOT-PLANT DENITRIFICATION RATE FOR RUN 4. 
Table 23

ANALYSES OF CUMULATIVE DRIED RESIDUES

\begin{tabular}{|c|c|c|c|c|c|c|c|c|}
\hline \multirow[b]{2}{*}{ Element } & \multicolumn{4}{|c|}{ Runs (\%) } & \multirow[b]{2}{*}{ Element } & \multicolumn{3}{|c|}{ Runs $(\%)$} \\
\hline & & 6 & & 7 & & 6 & & 7 \\
\hline \multicolumn{9}{|c|}{ Spectrographic } \\
\hline $\mathrm{Ag}$ & $<$ & 0.005 & $<$ & 0.005 & $\mathrm{Na}$ & 0.3 & & 1.0 \\
\hline $\mathrm{Al}$ & & 2.5 & & 1.5 & $\mathrm{Nb}$ & $<0.02$ & $<$ & 0.02 \\
\hline $\mathrm{Au}$ & $<$ & 0.02 & $<$ & 0.02 & $\mathrm{Ni}$ & $<0.01$ & $<$ & 0.01 \\
\hline B & $<$ & 0.01 & $<$ & 0.01 & $\mathbf{P}$ & $<1.0$ & $<$ & 1.0 \\
\hline $\mathrm{Ba}$ & $<$ & $0.0 n ?$ & $<$ & 0.002 & $\mathrm{~Pb}$ & $<0.01$ & $<$ & 0.01 \\
\hline $\mathrm{Be}$ & $<$ & 0.001 & $<$ & 0.001 & $\mathrm{Pd}$ & $<0.002$ & $<$ & 0.002 \\
\hline $\mathrm{Bi}$ & $<$ & 0,01 & $<$ & 0.01 & RL & $\div 0.95$ & $<$ & 0.15 \\
\hline $\mathrm{Ca}$ & $>2$ & 20.0 & & 20.0 & Sb & $\div 0.04$ & $<$ & 0.04 \\
\hline $\mathrm{Cd}$ & $<$ & 0.04 & $<$ & 0.04 & $\mathrm{Si}$ & 0.25 & & 0.08 \\
\hline Co & $<$ & 0.005 & $<$ & 0.005 & Sn & $<0.005$ & & 0.01 \\
\hline $\mathrm{Cr}$ & $<$ & 0.01 & $<$ & 0.01 & Ta & $<0.15$ & $<$ & 0.15 \\
\hline Cs & $<$ & 0.6 & $<$ & 0.6 & Th & $<0.04$ & $<$ & 0.04 \\
\hline $\mathrm{Cu}$ & $<$ & 0.005 & $<$ & 0.005 & $\mathrm{Ti}$ & $<0.01$ & $<$ & 0.01 \\
\hline $\mathrm{Fe}$ & & 0.3 & & 0.05 & $u^{(1)}$ & 0.0002 & & 0.00003 \\
\hline $\mathrm{Ht}$ & $<$ & 0.02 & $\therefore$ & 0.02 & V & $\therefore 0.005$ & $<$ & 0.005 \\
\hline K & & 0.04 & & 0.08 & $w$ & $<0.08$ & く & 0.08 \\
\hline $\mathrm{Mg}$ & & 0.5 & & 0.3 & $\mathrm{Zn}$ & $<0.08$ & $<$ & 0.08 \\
\hline $\mathrm{Mn}$ & & 0.01 & & 0.005 & $\mathrm{Zr}$ & $<0.002$ & $<$ & 0.002 \\
\hline \multicolumn{9}{|c|}{ Chemical } \\
\hline C & & 1.0 & & 1.110 & $\mathrm{NO}_{3}-(2)$ & 0.205 & & 0.136 \\
\hline $\mathrm{Ca}$ & & & & 29.88 & $\mathrm{CO}_{3}^{-2}$ & & & 46.23 \\
\hline$N$ & & 0.202 & & 2.58 & LOD $(3)$ & 6.32 & & 2.40 \\
\hline \multicolumn{9}{|c|}{$\times$ Ray } \\
\hline
\end{tabular}

$\mathrm{CaCO}_{3}$ (calcite), hexagonal structure

(1) By fluorimetric uranium analyses.

(2) Water-soluble $\mathrm{NO}_{3}$ - leached from dried solids.

(3) LOD - loss on drying, after initial air drying. effluents. Similar results occur when sodium hydroxide is used to neutralize the raffinates except that final precipitation is limited to the small amount of calcium carbonate originally contained in the organic solution. Sodium carbonate remains in solution because of its solubility. Samples from the suspended bed reactor confirms, in all cases, that a ply rise at the end of the batch run resulis in subsequent clarification of the reactor solution.

Mass spectrographic analyses of gaseous effluents resulting from biological denitrification are presented in Table 24. The analyses represent gas compositions at various denitrification rates for different batch runs Run 5 represents idealized roactor conditinns, with the offgases consisting primarily of nitrogen and carbon dioxide. The other analyses indicate less than idcal conditions with varying percentages of nitric oxide in the effluent gases.

Talule 24

ANALYSES OF GASEOUS EFFLUENTS FROM DENITRIFICATION

\begin{tabular}{|c|c|c|c|c|c|c|c|c|c|}
\hline \multirow{3}{*}{$\begin{array}{c}\text { Sample } \\
\text { Date } \\
\text { (1973) } \\
\end{array}$} & \multicolumn{2}{|c|}{$\begin{array}{l}\text { Menitrification } \\
\text { Rate }\end{array}$} & \multirow{2}{*}{\multicolumn{7}{|c|}{ Gaseous Effluent $(1)$ (vol \%) }} \\
\hline & Number & & & & & & & & \\
\hline & of Runs & $(\mathrm{g} / \mathrm{day} / \mathrm{dm} 3)$ & $\mathrm{CO}_{2}$ & $\mathrm{Ar}$ & $\mathrm{O}_{2}$ & $\mathrm{~N}_{2}$ & $\mathrm{H}_{2}$ & NO & $\mathrm{CH}_{4}$ \\
\hline \multirow[t]{2}{*}{$8-23$} & 4 & 1.75 & 68.50 & 0.0028 & 0.044 & 22.85 & & 8.60 & \\
\hline & & & 69.47 & 0.0019 & 0.042 & 21.82 & & 8.67 & \\
\hline \multirow[t]{2}{*}{$9-4$} & 5 & 3.25 & 32.22 & 0.006 & 0.05 & 67.69 & & 0.0.3 & \\
\hline & & & 31.82 & 0.0003 & 0.05 & 68.10 & & 0.03 & \\
\hline \multirow[t]{2}{*}{$9-5$} & 5 & 2.90 & 38.30 & $<0.0005$ & 0.03 & 58.77 & & 2.90 & \\
\hline & & & 37.30 & $<0.0005$ & 0.03 & 57.77 & & 2.89 & \\
\hline \multirow[t]{2}{*}{$10-24$} & 8 & 5.4 & 26.42 & 0.04 & 0.10 & 67.00 & 0.03 & 5.43 & 0.98 \\
\hline & & & 26.42 & 0.04 & 0.10 & 67.00 & 0.03 & 5.43 & 0.98 \\
\hline
\end{tabular}

(1) Analyses are by mass spectrometry. 
Calculations based on recorded temperature reading observed during periods of steady-state denitrification operation indicate that the heat of reaction is approximately $65.6 \mathrm{kcal}$ per gram mole of nitrate decomposed. Because of this energy release, the reactor temperature ranged from 303 to $311 \mathrm{~K}$, depending on the vigor of the reaction.

Continuous Pilot-Plant Operations - Subsequent to the completion of the eight batch runs in the biodenitrification pilot plant, minor modifications were made to permit the facility to operate in a continuous mode. Initial batch operations had adequately demonstrated the feasibility of operating the pilot plant on acid condensates and raffinates (plant acidic, nitrate wastes). However, continuous operation of the facility would consume more nitrate wastes than it would be possible to properly withdraw because of uranium criticality safety limitations and the lack of nuclear safe storage tanks to hold the acid wastes until analytical results confirmed that it was safe to introduce the waste solutions into the reactor. Therefore, other sources of nitrate ion were investigated.

Industrial-grade calcium nitrate was available on a tonnage basis. This chemical contained, nominally, $81 \%$ calcium nitrate, Table 25 . No toxicity from its use was anticipated and none developed, although it contained $4.8 \mathrm{wt} \%$ ammonium nitrate. A nominal $546 \mathrm{~kg}$ of calcium nitrate was dissolved in $0.6 \mathrm{~m}^{3}$ of water in the dissolver tank to give a dissolved calcium nitrate concentration of $910 \mathrm{~kg} / \mathrm{m}^{3}(\sim 50 \mathrm{wt} \%)$. Nitrate solution was then diluted with water and mixed with proportional quantities of water and either calcium acetate solution or methanol to provide the necessary soluble organic carbon substrate requirement. Adjusted feeds currtaining approximately 10 wt $\%$ ion were then transferred to the $3.8 \mathrm{~m}^{3}$ feed tank for continuous metering into the suspendedbed reactor.

Other sources of nitrate feed materials for the pilot-plant operation were acidified aluminum nitrate solution, approximating the composition of a concentrated raffinate solution (45 to $50 \%$ $\mathrm{NO}_{3}{ }^{-}$, and $70 \%$ nitric acid. These acidic materials were added directly to the reactor for two

Table 25

COMPOSITION OF INDUSTRIAL. GRADE CALCIUM NITRATE

\begin{tabular}{lc}
\hline \multicolumn{1}{c}{ Chemical } & $\begin{array}{c}\text { Content } \\
(\%)\end{array}$ \\
\hline Calcium Nitrate [as $\mathrm{Ca}\left(\mathrm{NO}_{3}\right)_{2}$ ] & 81.0 \\
Magnesium Nitrate [as $\mathrm{Mg}_{2}\left(\mathrm{NO}_{3}\right)_{2}$ ] & 1.0 \\
Ammonium Nitrate [as $\mathrm{NH}_{4} \mathrm{NO}_{3}$ ] & 4.8 \\
Water [as $\mathrm{H}_{2} \mathrm{O}$ ] & 14.0 \\
& $(\mathrm{mg} / \mathrm{kg}$ ) \\
Insolubles in Water & 100 \\
Phosphorus (as $\mathrm{P}_{2} \mathrm{O}_{5}$ ) & $\mathrm{Nil}$ \\
Sulfates (as $\mathrm{SO}_{4}{ }^{-2}$ ) & 350 \\
Chlorine (as $\mathrm{Cl}^{-}$) & 15 \\
Strontium & $\mathrm{Nil}$ \\
Manganese (as $\mathrm{Mn}$ ) & 20 \\
Sodium las $\mathrm{Na}$ ) & 100 \\
Iron las $\mathrm{Fe}$ ) & 2 \\
Copper (as Cu) & 0.05 \\
Heavy Metals (as $\mathrm{Pb}$ ) & 1 \\
\hline
\end{tabular}
reasons: (1) to dissolve the calcite, and (2) to determine their effect in the reactor. There appeared to be no significant biological shock as a result of periodic additions because the acidic materials rapidly reacted with the accumulated basic ions and calcite in the recirculating system or the sludge in the bottom of the rcactor. Acidic materials were very effective in dissolving the hard accretions of calcite scale deposited in the piping and pump check valves. Plugged lines and checks were formerly a source of difficulty, resulting in loss of time for maintenance repairs and, if for an extended period of time, it always resulted in hydraulic shock to the microorganisms. During use of acidic feed materials, some decrease in the $\mathrm{pH}$ frequently occurred due to carbon dioxide generation resulting from additions of the feed solution. Low $\mathrm{pH}$ values were raised by the addition of lime hydrate slurry or sodium hydroxide solution. 
Phosphates were dissolved in measured volumes of filtered water and the solutions metered into the reactor as required. Experience indicated that most micronutrients were present as impurities in the various feed materials, and supplemental additions were unnecessary.

Gaseous and aqueous effluents leaving the pilot-plant reactor were measured and analyzed to obtain daily material balance data from which it was possible to evaluate the operating performance. Settled solids were removed periodically i $ı$ U.I $\mathrm{m}^{3}$ wlthdraw'sls approximately every ten days) through a bottom drain valve into drums for transport to the solid wastes burial ground.

rnntinınus nperation of the suspended-bed denitrification pilot plant facility began on February 13, 1974. Feed composition was approximately $10 \mathrm{wt} \%$ nitrate ion, $2.35 \mathrm{wt} \%$ TOC, a pH of 8.76, and a specitic gravity of 1.1245. In an initial incubation period, required to develop the biological log-growth phase which is essential tor continuous operallun, llite solution in the suspended-growth reactor analyzed $2.86 \mathrm{wt} \%$ nitrate. As a result, minimal feed introduction at a rate of $0.75 \mathrm{~g} \mathrm{NO}_{3}^{-} /$day/dm 3 was maintaned for approximately three days (Table A-13) to reduce the concentration in the reactor. By the third day, the nitrate effluent loss was $0.074 \mathrm{~g} \mathrm{NO}_{3}^{-} / \mathrm{day} / \mathrm{dm}^{3}$ with an average of $7.0 \mathrm{~g} \mathrm{NO}_{3}^{-} / \mathrm{day} / \mathrm{dm}^{3}$ being reduced. An increase in the feed rate was then made as bioloyical activity improved. Average nitrate feed rate for the 15 days of February was $50.97 \mathrm{~kg} / \mathrm{day}\left(5.1 \mathrm{~g} / \mathrm{day} / \mathrm{dm}^{3}\right)$ with $48.436 \mathrm{~kg} /$ day $\left(4.84 \mathrm{~g} \mathrm{NO}_{3}^{-} /\right.$day $\left./ \mathrm{dm}^{3}\right)$ being reduced for a $95.03 \%$ nitrate reduction efficiency. These rates indicated that the reactor performance was exceeding the designed throughput rates of $40 \mathrm{~kg} /$ day $\left(4 \mathrm{~g} \mathrm{NO}_{3}{ }^{-} /\right.$day $\left./ \mathrm{dm}^{3}\right)$.

By the sixteenth day (March 1, 1974) the biological log growth phase was sufficiently established to support continuous feeding, as evidenced by the high level of nitrate reduction efficiency which followed over the next 50 days of operation, up to April 20 , 1974 (Tables A-14 and A-15). Nitrate-reduction efficiencies during this period ranged from 98.42 to $99.97 \%$. Effluent losses were well below $0.1 \mathrm{~kg}$ per day $10.01 \mathrm{~g} / \mathrm{day} / \mathrm{dm} 3$ ) practically every day from March 1 to April 20, 1974. Total nitrate ion reduced was 1777 $\mathrm{kg}$-a daily average of $35.54 \mathrm{~kg} /$ day $\left(3.55 \mathrm{~g} \mathrm{NO}_{3} /\right.$ day $\left./ \mathrm{dm}^{3}\right)$.

A drastic change in the reduction efficiency occurred on April 20, 1974, brought on by slowly changing the organic feed from calciurn acetate to methanol. Prior to this introduction, the microorganisms had become well adjusted to acetate carbon as their energy source. Minimal feeding [15.3 kg (1.5 g/day/dm 3 ) of methanol over 12 days ("lable A-15) $\}$ was used prior to Day 66 , since a gradual transition to methanol was planned. The first evidence that biological shock was occurring was a sharp increase in the nitrate ion in the effluent. This upset resulted in a $9.6 \%$ decrease in the nitrate reduction efficiency (lo $90.35 \%)$. Simultaneously, the nitrate concentration in the reactor recirculating system rose from 0.05 to 2.2 wt $\% \mathrm{NO}_{3}{ }^{-}$. Nitrate feed was stopped for the next five days and an additional $92.7 \mathrm{~kg}\left(9.27 \mathrm{~g} \mathrm{CH}_{3} \mathrm{OH} / \mathrm{dm}^{3}\right)$ of methanol carbon were added to alleviate an apparent carbon deficiency. Because of the high effluent nitrate values, the effluent was recycled from April 25 through May 13, 1974, except for one day [April 30, 1974 (Tables A-15 and A-16)]. It soon became apparent that the microorganisms were in a state of shock and methanol, carbon was not biologically acceptable as a carbon energy source to the then-existing biological population. The quantity of useable acetate carbon had gradually been exhausted since it had been reduced in quantity in favor of methanol. 
Supplemental additions of calcium acetate carbon were resumed throughout the month of May to maintain a viable population of microorganisms. As a result of dual feeding of organic carbon (acetate plus methanol) the TOC rose to approximately $1.7 \mathrm{wt} \%$ during May. Analysis indicated that the organic remaining was largely methanol carbon, which was apparently unacceptable to the microorganisms.

A further complication, occurring on April 22, 1974, aggravated the biological shock already induced by a change in the organic feed. A two-inch suction line to the diaphragm pump and its check valves became inoperative due to accumulations of calcite deposits. Approximately 16 hours of maintenance time were required to clean the recirculating system, inducing hydraulic shock to this system. Nitric acid was used to dissolve the calcite deposits by installation of an acid-injection nozzle at the bottom of the reactor in the pump suction line (Figure 18). A total of $115 \mathrm{~kg}\left(0.0115 \mathrm{~kg} / \mathrm{m}^{3}\right)$ of nitric acid nitrate were introduced in the lines which were completely cleaned of calcite scale. An additional $57 \mathrm{~kg}$ $\left(0.0057 \mathrm{~kg} / \mathrm{m}^{3}\right)$ of acid were added between April 30 and May 12, 1974. This addition was supplemented with approximately $30 \mathrm{~kg}\left(0.003 \mathrm{~kg} / \mathrm{m}^{3}\right)$ of calcium acetate carbon (Table A-16). When all effluents were recycled from May 1 through May 12, the nitrate content in the reactor decreased from 1.5 to $0.015 \mathrm{wt} \%$. This change indicated that an active population of microorganisms could be revitalized if the feed contained acetate carbon. With two types of organic carbon being supplied to the reactor, the $\mathrm{C} / \mathrm{N}$ ratio in the feed rose to 2.5:1. It appeared from the results of daily gas chromatograph analyses that possibly $40 \%$ of the methanol was being assimilated along with the acetate carbon, although the latter was more acceptable to the microorganisms. As reported in Table A-16, daily nitrate reductions during early May are 12-day averages because of effluent recycling.

On May 13, 1974 (Day 89, Table A-16), feeding and removal of effluents were resumed. Feed composition introduced was 9.47 wt \% nitrate ion as calcium nitrate, $1.6 \mathrm{wt} \%$ methanol carbon, and $1.4 \mathrm{wt} \%$ acetate carbon. Initially, this effluent contained less than $0.01 \% \mathrm{NO}_{3}{ }^{-}$; however, in three days, the effluent rose to $0.4245 \mathrm{wt} \%$ nitrate with a drop in reduction efficiency. Recycling was resumed again with further supplemental feeding of calcium acetate carbon. Daily analyses indicated that methanol carbon was increasing in the reactor (0.8-0.9 wt \%) and that the microorganisms were consuming only the acetate carbon. After the addition of $13 \mathrm{~kg}$ of acetate carbon and by recycling the effluent, the nitrate content was again lowered to $0.01 \mathrm{wt} \%$, permitting resumption of continuous feeding through May 27, 1974, at which time recycling of the effluent was again required. During May, the $\mathrm{C} / \mathrm{N}$ ratio in the feed was 2.12:1, which is based on the two organic substrates employed.

A characteristic of incomplete reaction was the presence of 0.02 to 0.09 wt $\%$ nitrite ion in the reaclur recirculating system. Nitrite ion concentrations in the reactor during normal efficient operation are usually less than $0.0005 \%$, increasing in value only due to unstable operaling conditions. High nitrite values were generally evident when the $\mathrm{pH}$ was below 6.8 . Above 6.8, nitrite values normally remained low. For example, when the $\mathrm{pH}$ values dropped below 6.8, from May 23 to May 29, inclusive (Table A-16), the nitrite concentration in the reactor increased to 0.1 vol \% and remained at that level until the $\mathrm{pH}$ was maintained consistenlly above 7.0. High nitrate ion concentration is a precursor for high nitrate ion concentrations in the effluent and, consequently, lower reduction efficiencies. 
Due to the difficulty in getting the acetate carbon microorganisms to accept a methanol carbon substrate for cell reproduction and synthesis, overall nitrate reduction in May was reduced to a daily average of $12.69 \mathrm{~kg} \mathrm{NO}_{3}^{-} /$day $\left(1.27 \mathrm{~g} \mathrm{NO}_{3}^{-} /\right.$day/dm 3$)$, compared to $51.0,37.8$, and $27.2 \mathrm{~kg} /$ day $(5.1,3.78$, and $2.72 \mathrm{~g} / \mathrm{day} / \mathrm{dm} 3$ ) in February, March, and Apri!, respectively (Tables $A-13$ through $A-16)$.

Indicative of methanol substrate rejection was the $\mathrm{C} / \mathrm{N}$ ratio of $2.12: 1$ for the total carbon feed versus a $\mathrm{C} / \mathrm{N}$ ratio of 1.14:1 for the calcium acetate carbon input. The latter was comparable to 1.15:1 for both February and March when the substrate electron donor was acetate carbon. It appears that acetate-adjusted microorganisms will require an acclimation period prior to accéptance of a diffelenll cal buri substrate.

As the month of May erided, very unstable conditions prevalled in the reactor, requli'lng recycling of the effluent to reduce excessive nitrate loss. Concentrations in the reactor recirculating system were $1.19 \%$ riliate ivi, $1.44 \%$ TOC, $0.071 \%$ nitritc ion, and $0.08 \%$ ammonium ion. Due to these high values, no blends of calcium nitrate-calcium acetate feed were used in June. In fact, no organic feed was required throughout June due to the initial high concentration of carbon in the reactor. Nitrate feeds utilized in June (Table A-17) consisted of occasional low-volume injections of $70 \%$ nitric acid for calcite removal from the recirculating system, four additions of calcium nitrate solution, and injections of acidified aluminum nitrate (AAN). Due to the absence of any organic and because the nitrate feed materials consisted primarily of concentrated nitrate ions $\left(\mathrm{HNO}_{3}\right.$ or $\left.\mathrm{AAN}\right)$, no discards of effluents were made during the entire month of June.

During June, a total of $317.6 \mathrm{~kg}$ of nitrate ion were decomposed (Table A-17). The averaye daily nitrate reduction amounted to $10.59 \mathrm{~kg} /$ day $\left(1.06 \mathrm{~g} \mathrm{NO}_{3}^{-} / \mathrm{ddy} / \mathrm{dm}^{3}\right)$. Likewise, the $10 \mathrm{C}$ : utilization was $126.66 \mathrm{~kg}\left(0.422 \mathrm{~g} \mathrm{C} / \mathrm{day} / \mathrm{dm}^{3}\right)$, resulting in an overall $\mathrm{C} / \mathrm{N}$ ratio of 1.74:1 tor June. It appears from this higher-lharl-riormal consumptive ratio that there was some forced acceptance of methanol carbon. Both the nitrite and ammulurium ions were lowcred during the month.

As was the case in June, no effluent was withdrawn from the suspended growth reactor in July 1974, also due to continued utilization of concentrated nitrăte feeds and minimial additions of organic solution (Table A-18). By July 12, TOC analyses indıcated that organic carbon had dropped to $0.51 \mathrm{wt} \%$; however, the nitrate concentration in the reactor had increased from 0.255 to $1.01 \mathrm{wt} \%$ after feeding $86.54 \mathrm{~kg}$ of AAN and $56.20 \mathrm{~kg}$ of calcium nitrate solution. Although the C/PN ialiu in llie i eactur was 1.52: 1, there appoarod to bo an Insufficiency of carbun (TOC) beciuse the TOC present was largcly mothanol carbon and was not being utilized by the microorganisrrus. Further additions of AAN resulted in a further increase in the reactor nitrate concentration (1.2\%). Five kilograms of calcium acetate were added on July 18 in an effort to reactivate the microorganisms. An immediate response occurred, with approximately $55 \mathrm{~kg}$ of nitrate being reduced over the next 12 days $\left(0.46 \mathrm{~g} \mathrm{NO}_{3}^{-} /\right.$day $\left./ \mathrm{dm}^{3}\right)$. An additional $22.6 \mathrm{~kg}$ of acetate carbon were added up to the end of July, with a nitrate reduction of $24.58 \mathrm{~kg}$ on July 31 .

Total nitrate reduced in July was $158.56 \mathrm{~kg}$, a daily average of $5.11 \mathrm{~kg} /$ day $10.511 \mathrm{~g}$ $\mathrm{NO}_{3}-/$ day $/ \mathrm{dm}^{3}$ ). Based on three months of generally unstable operation of the pilot plant 
using methanol calcium acetate as the energy substrate, it was concluded that acetate carbon was superior to a methanol acetate carbon substrate under conditions existing in the reactor.

Mass spectrographic analyses of the effluent gases generated in the reactor were taken at intervals to identify the gases involved (Table 26). Sample 1, taken April 2, 1974, represents a typical gas analysis during a period of sustained high-reduction efficiency where effluent gases are largely carbon dioxide and nitrogen. Samples 2, 3, and 4 (taken April 26 and 29) represent deteriorating reactor conditions resulting from the gradual introduction of methanol into the reactor. Nitrogen was being partially replaced by nitric oxide gas. Due to high nitrate analyses, the effluent was being recycled. During this period of operation, the nitrate concentration in the reactor rose from 0.03 to $2.0 \mathrm{wt} \%$, and the nitrite ion increased from 0.0005 to $0.27 \%$. Sample 5 (May 3) was taken during a period when nitrogen gas was being used to pressurize the reactor. Samples 6 through 11 represent gas analyses which showed relatively high methane concentrations in the effluent gases, indicative of unstable reaction kinetics resulting from additions of methanol carbon substrate. As shown by Table 26 , methanal also is exerting a slight vapor pressure in the reactor.

Table 26

MASS SPECTROGRAPHIC ANALYSES OF THE EFFLUENT GAS FROM THE REACTOR

\begin{tabular}{|c|c|c|c|c|c|c|c|c|c|}
\hline \multirow{2}{*}{$\begin{array}{l}\text { Sample } \\
\text { Number }\end{array}$} & \multirow{2}{*}{$\begin{array}{c}\text { Date } \\
(1974)\end{array}$} & \multicolumn{7}{|c|}{ Gas Concentration (vol \%) } & \multirow[b]{2}{*}{ Remarks } \\
\hline & & $\mathrm{CO}_{2}$ & $\mathrm{Ar}$ & $\overline{\mathrm{O}_{2}}$ & $\mathrm{~N}_{2}$ & $\mathrm{CH}_{3} \mathrm{OH}$ & NO & $\overline{\mathrm{CH}_{4}}$ & \\
\hline 1 & $4-2$ & 41.68 & 0.006 & 0.16 & 58.15 & - & - & - & After $\mathrm{PO}_{4}{ }^{-3}$ \\
\hline 2 & $4 \cdot 26$ & 40.10 & 0.01 & 0.14 & 48.98 & 0.07 & 10.69 & - & $\mathrm{CH}_{3} \mathrm{OH}$ added. Recycling effluent. \\
\hline 3 & $4-26$ & 49.00 & 0.01 & 0.15 & 37.78 & 0.09 & 12.97 & & $\mathrm{CH}_{3} \mathrm{OH}$ added. Drain sludge; add teed. \\
\hline 4 & $4-29$ & 60.72 & 0.01 & 0.77 & 23.78 & 0.23 & 14.48 & & Recycling. \\
\hline 5 & $5-3$ & 4.84 & 0.02 & 0.06 & 93.78 & 0.03 & 1.25 & & Nitrogen purye. \\
\hline 6 & 5-14 & 28.00 & - & 0.16 & 65.59 & 0.14 & 0.08 & 6.03 & Feeding $50 \% \mathrm{CH}_{3} \mathrm{OH} 50 \% \mathrm{Ca}\left(\mathrm{C}_{2} \mathrm{H}_{3} \mathrm{O}_{2}\right)_{2}$ \\
\hline 7 & 5-15 & 32.21 & 0.001 & 0.19 & 60.26 & 0.14 & 0.56 & 6.63 & Continuous operation. \\
\hline 8 & $5-16$ & 46.06 & 0.004 & 0.15 & 44.11 & 0.12 & 2.78 & 6.77 & Continuous operation. \\
\hline 9 & 5.17 & 56.18 & 0.007 & 0.33 & 35.85 & 0.26 & 3.92 & 3.45 & Recycling; no effluent. \\
\hline 10 & $5 \cdot 20$ & 53.47 & 0.006 & 0.24 & 37.63 & 0.24 & 0.53 & 7.98 & Feeding $\mathrm{CH}_{3} \mathrm{OH}+\mathrm{Ca}\left(\mathrm{C}_{2} \mathrm{H}_{3} \mathrm{O}_{2} \mathrm{I}_{2}\right.$. \\
\hline 11 & $5-24$ & 61.86 & 0.03 & 0.30 & 25.11 & $0: 21$ & 7.30 & 4.84 & Feeding $\mathrm{CH}_{3} \mathrm{OH}+\mathrm{Ca}_{2}\left(\mathrm{C}_{2} \mathrm{H}_{3} \mathrm{O}_{2} \mathrm{I}_{2}\right.$. \\
\hline
\end{tabular}

The reactor tests were stopped on July 31,1974 , but will be reactivated at a later date if additional engineering design data are required.

\section{CONCLUSIONS}

\section{Columnar Denitrification Studies}

These studies have shown that denitrification of nitrate acid wastes can be successfully accomplished by using columns packed with coal or plastic rings. The system will operate on feeds containing such soluble carbonate salts as sodium, potassium, and ammonium. Insoluble carbonate salts, such as calcium, will cause plugging of the column. Denitrification rates up to 122 grams of nitrate per day per cubic decimeter of packing material were obtained in these studies. 


\section{Laboratory Denitrification Studies}

Four stirred-bed reactors were operated for a total of 453 days, and design information was obtained for scaleup to a plant-sized unit. Denitrification rates of up to 10 grams of nitrate per day per cubic decimeter of reactor solution were obtained. The following conclusions can be made from these studies:

Mini I Reactor - It was demonstrated that:

1. Denitrification of calcium nitrate using calcium acetate as the carbon source was successful.

2. Gravity feed systems were not satisfactory because the low liquid flows to the reactor could not be adequately controlled or maintained.

3. Feed solutions containing 10 to $14 \mathrm{wt} \%$ nitrate ions were successfully fed to the reactor.

4. The carbon-to-nitrogen mole ratio in the feed and in the reactor solution is an important variable. The data suggest that a low $\mathrm{C} / \mathrm{N}$ mole ratio and also a very high $\mathrm{C} / \mathrm{N}$ mole ratio may be detrimental. A "best-guess" satisfactory $\mathrm{C} / \mathrm{N}$ mole ratio in the reactor range may be 20 to 100 .

5. The system requires phosphate ions, and a level of $5 \mu \mathrm{g} / \mathrm{g}$ appears to be satisfactory.

Mini II Reactor - The first 30 days of reactor operation were used to start the reaction. Continuous feed was started, but a valve failure occurred and a large volume of acid feed was dumped into the vessel. The $\mathrm{pH}$ of the solution was adjusted with calcium hydroxide; and, withın 12 days, continuous leed was resumed (Day 50). From this date, the reactor satisfactorily operated 74 days out of à total of 83 te"sl days.

Mini III Reactor-Exclusive of the first 50 days of the test period, the Mini III reactor operated 150 test days. During this 150-day period, the feed flow was turned off four times for a total of seven days with the maximum perlod being lhire Uays. The exaet rcazons for the four shutdowns are not fully understood, but two of them are believed to have been caused by an excessive amount of organic carbon in the denitrification vessel.

Mini IV Reactor-Mini IV operated satisfactorily for 114 test days out of a total 134 tcst-day period. The reactor flow was temporarily cut off or reduced for one or more days when high nitrates were noted in the effluent from the reactor.

\section{Pilot-Plant Stirred-Bed Studies}

A $15 \mathrm{~m}^{3}$-sized vessel was successfully operated as a stirred-bed denitrification redclur. The denitrification rate obtained on this unit was 10 grams of nitrate per day per cubic decimeter of reactor solution, which is the same as that found on the laboratory-sized vessels. 


\section{REFERENCES}

(1) Francis, C. W. and Malone, C. D.; "Nitrate Measurements Using a Specific Ion Electrode in Presence of Nitrite", Soil Sci Soc Am Proc (In Press).

(2) Bremner, J. M.; "Nitrite by Colorimetric Methods", Methods of Soil Analysis - Part 2, Chemical and Microbiological Properties, pp 1219-1224, C. A. Block, Editor; American Society of Agronomy, Madison, Wisconsin (1965).

(3) Auerbach, S. I., et al; "Biological Denitrification of High-Nitrate Wastes", Environmental Sciences Division Annual Report, ORNL-4935, pp 13 -14; Oak Ridge National Laboratory, Oak Ridge, Tennessee (1974).

(4) Francis, C. W. and Callahan, M. W.; "Biological Denitrification and Its Application in the Treatment of High Nitrate Wastewaters", J Environ Qual (In Press).

(5) Francis, C. W. and Malone, C. D.; "Denitrification of Nitrate Concentrations $>1000$ ppm $\mathrm{NO}_{3}^{-}$in Continuous Flow Stirred Reactors"; To be Submitted to Water Resources Bulletin.

16) McCarty, P. L.; "Feasibility of the Denitrification Process for Removal of Nitrate-Nitrogen from Agricultural Drainage Waters", Appendix to California Department of Water Resources Bulletin, p 1743 (1969).

(7) Smith, J. M., Masse, A. N., Feige, W. A., and Kamphake, L. J.; "Nitrogen Removal from Municipal Waste Water by Columnar Denitrification", Environ Sci Tech, 6, (3), pp $260-267$ (1972).

(8) Moore, S. F. and Schroeder, E. D.; "The Effect of Nitrate Feed Rate on Denitrification", Water Res Bul, 5, pp 445 - 452 (1971).

(9) Requa, D. A. and Schroeder, E. D.; "Kinetics of Packed-Ren Menitrification", J Water Pollut Contr Fed, 4.5, pp 1696 - 1707 (1973).

(10) Stensel, H. D., Loehr, R. C., and Lawrence, A. W.; "Biological Kinetics. of Suspended-Growth Denitrification", J Water Pollut Contr Fed, 45, (2), pp 249 - 261 (1973).

(11) Lineweaver, H. and Burk, D; "Determination of Enzyme Dissociation Constants", J Am Chem Soc, 56, pp 658 - 667 (1934). 


\section{ACKNOWLEDGEMENTS}

Appreciation is extended to R. B. Bustamante, Civil Engineering Department, Tennessee Technological University, for his consultation and advice during these studies. Also, C. D. Malone of Tennessee Technological University obtained valuable information in the laboratory columnar denitrification studies. Thanks are also expressed to G. D. Novelli and his staff of the ORNL Biology Division for their assistance in supplying cultures and advice during these studies. 
APPENDIX

OPERATIONAL DATA ON THE FOUR MINI REACTORS 


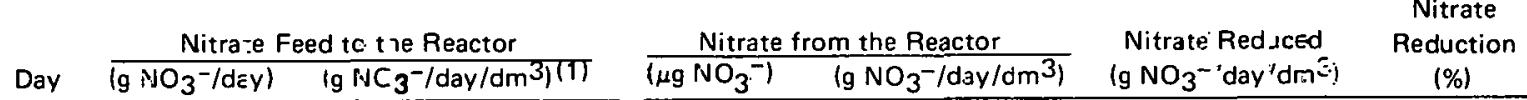

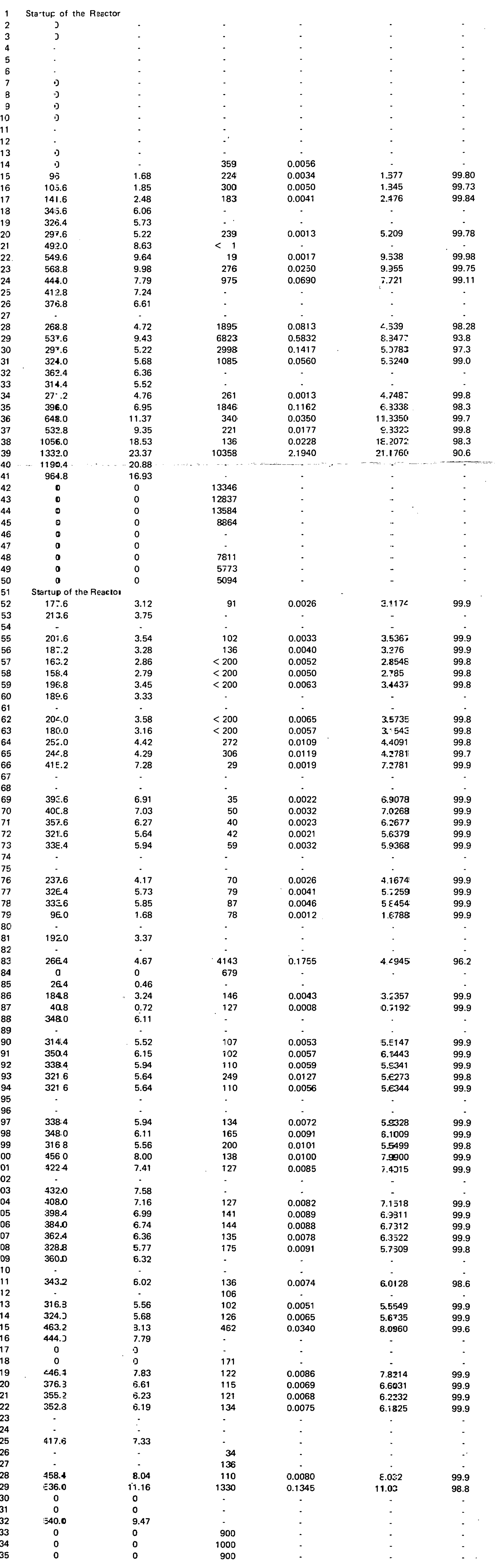

(1) $\mathrm{g} \mathrm{NO}_{3}$-/day/dm 3 is defined as grams of nitrate per day per $\mathrm{dm}^{3}$ of reactor solution. Volume 31 reacior was $0.757 \mathrm{~m}^{3}$. 
Table A-2

COMPOSITION OF LIQUID FROM THE MINI I REACTOR

\begin{tabular}{|c|c|c|c|c|c|c|c|c|c|c|c|c|c|c|}
\hline \multirow{3}{*}{$\begin{array}{l}\text { Test } \\
\text { Day } \\
\end{array}$} & \multicolumn{6}{|c|}{ Analysis of Liquid from the Reactor $(\mu \mathrm{g} / \mathrm{g})$} & \multirow{3}{*}{$\begin{array}{c}\begin{array}{c}\text { Test } \\
\text { Day }\end{array} \\
69\end{array}$} & \multicolumn{7}{|c|}{ Analysis of Liquid from the Reactor $(\mu \mathrm{g} / \mathrm{g})$} \\
\hline & \multirow{2}{*}{$\frac{\mathrm{NO}_{3}^{--}}{-}$} & \multirow{2}{*}{ TOC } & \multirow{2}{*}{$\mathrm{NO}_{2}^{-}$} & $\mathrm{NH}_{4}{ }^{+}$ & & $4^{-3}$ & & $\overline{\mathrm{NO}_{3}-}$ & TOC & & $\mathrm{OO}_{2}^{-}$ & $\mathrm{NH}_{4}{ }^{+}$ & PO & $4^{-3}$ \\
\hline & & & & . & & . & & 35 & . & $<$ & 5 & 748 & $<$ & 5 \\
\hline 2 & - & - & . & . & & . & 70 & 50 & . & $<$ & 5 & 868 & $<$ & 5 \\
\hline 3 & . & - & . & . & & - & 71 & 40 & . & $<$ & 5 & 804 & $<$ & 5 \\
\hline 4 & - & - & - & - & & - & 72 & 42 & . & $<$ & 5 & 942 & $<$ & 5 \\
\hline 5 & $\cdot$ & . & - & - & & . & 73 & 59 & . & & 5 & 1305 & $<$ & 5 \\
\hline 6 & - & - & . & - & & . & 74 & - & - & & . & . & & . \\
\hline 7 & - & - & . & . & & - & 75 & . & 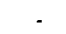 & & - & . & & . \\
\hline 8 & - & . & . & - & & . & 76 & 70 & . & $<$ & 5 & 1475 & $<$ & 5 \\
\hline 9 & . & . & . & . & & . & 77 & 79 & 975 & $<$ & 5 & 2448 & & . \\
\hline 10 & - & - & - & . & & . & 78 & 87 & . & $<$ & 5 & 4526 & & . \\
\hline 11 & - & - & - & - & & . & 79 & 78 & - & $<$ & 5 & 3251 & & . \\
\hline 12 & - & . & . & . & & . & 80 & - & . & & - & - & & - \\
\hline 13 & - & . & - & - & & - & 81 & . & - & & . & - & & . \\
\hline 14 & 359 & - & . & . & & . & 82 & . & . & & . & . & & . \\
\hline 15 & 224 & 975 & $<0.1$ & - & & - & 83 & 4143 & 3540 & & 1030 & 4479 & & . \\
\hline 16 & 300 & 1138 & $<0.1$ & . & & . & 84 & 679 & 1650 & $<$ & 10 & 3602 & $<$ & 5 \\
\hline 17 & 183 & 825 & 0.1 & - & & - & 85 & . & . & & . & . & & - \\
\hline 18 & - & & . & . & & . & 86 & 146 & 3175 & $<$ & 5 & 3691 & $<$ & 5 \\
\hline 19 & - & - & - & - & & - & 87 & 127 & 2725 & $<$ & 10 & 4110 & $<$ & 10 \\
\hline 20 & 239 & 1800 & $<10$ & . & & - & 88 & - & . & & - & - & & . \\
\hline 21 & $<1$ & 1875 & $<0.1$ & . & & . & 89 & . & . & & - & . & & - \\
\hline 22 & 19 & 1012 & 763 & $\therefore$ & & - & 90 & 107 & 2300 & $<$ & 10 & 3990 & $<$ & 5 \\
\hline 23 & 276 & 625 & 1811 & . & & . & 91 & 102 & 2200 & $<$ & 5 & 3971 & $<$ & 5 \\
\hline 24 & 975 & 250 & 755 & . & & . & 92 & 110 & 2600 & $<$ & 5 & 3787 & $<$ & 5 \\
\hline 25 & - & . & . & - & & - & 93 & 249 & 2500 & $<$ & 5 & 4757 & $<$ & 5 \\
\hline 26 & . & . & - & 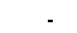 & & - & 94 & 110 & 2150 & $<$ & 5 & 4618 & $<$ & 5 \\
\hline 27 & . & . & - & - & & . & 95 & - & 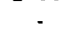 & & - & - & & . \\
\hline 28 & 1875 & 775 & $<10$ & . & & . & 96 & . & . & & . & . & & . \\
\hline 29 & 6823 & 2213 & $<10$ & . & & - & 97 & 134 & 2350 & $<$ & 10 & 3694 & $<$ & 5 \\
\hline 30 & 2998 & 1225 & 1200 & . & & . & 98 & 165 & 2650 & & 20 & 4544 & $<$ & 5 \\
\hline 31 & 1085 & 750 & 146 & . & & - & 99 & 200 & 2450 & $<$ & 5 & 4138 & $<$ & 5 \\
\hline 32 & - & . & - & . & & - & 100 & 138 & 2425 & $<$ & 10 & 3962 & $<$ & 5 \\
\hline 33 & . & - & - & . & & . & 101 & 127 & 2500 & $<$ & 5 & 4082 & $<$ & 5 \\
\hline 34 & 261 & 700 & $<10$ & - & & . & 102 & . & . & & - & - & & - \\
\hline 35 & 1846 & 2263 & $<10$ & . & & . & 103 & . & . & & - & . & & . \\
\hline 38 & 340 & 1850 & $<10$ & . & & . & 104 & 127 & 2775 & $<$ & 5 & 3556 & $<$ & 5 \\
\hline 37 & 221 & 3006 & - & . & & . & 105 & 141 & 2725 & $<$ & 10 & 4064 & $<$ & 5 \\
\hline 38 & 136 & 281 & . & . & & . & 106 & 144 & 3225 & $<$ & 5 & 3417 & $<$ & 5 \\
\hline 39 & 10358 & 6150 & 4480 & . & & . & 107 & 135 & 3075 & $<$ & 5 & 4055 & $<$ & 5 \\
\hline 40 & . & - & - & - & & - & 108 & 175 & 3775 & $<$ & 5 & 4175 & $<$ & 5 \\
\hline 41 & - & . & . & . & & . & 109 & - & : & & - & - & & - \\
\hline 42 & 13346 & 7012 & 4505 & . & & - & 110 & . & : & & . & . & & - \\
\hline 43 & 12837 & 9075 & 4316 & . & & . & 111 & 136 & 3700 & $<$ & 5 & 3390 & $<$ & 5 \\
\hline 44 & 13584 & 7425 & 4662 & - & & . & 112 & 106 & 3500 & $<$ & 5 & 3962 & $<$ & 5 \\
\hline 45 & 8864 & 5900 & 4212 & $=$ & & . & 113 & 102 & 1376 & ? & 6 & 3051 & $<$ & 5 \\
\hline 46 & . & - & - & . & &. & 111 & 126 & 4026 & $<$ & 5 & 3704 & $<$ & 5 \\
\hline 47 & . & . & - & . & & . & 115 & 462 & 4050 & & 183 & 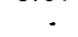 & $<$ & 5 \\
\hline 48 & 7811 & 6950 & 5017 & . & & . & 116 & . & . & & . & . & & - \\
\hline 49 & 5773 & 3975 & 4285 & . & & . & 117 & - & - & & - & . & & . \\
\hline 50 & 5094 & 3240 & 4547 & - & & - & 118 & 171 & 3875 & $<$ & 5 & 3537 & & 18 \\
\hline 51 & Change & Solutio & in the $R$ & & & & 119 & 122 & 3600 & $<$ & 5 & 3297 & $<$ & b \\
\hline 52 & 91 & $<1$ & $<10$ & 312 & $<$ & 5 & 120 & 115 & . & $<$ & 5 & 3149 & $<$ & 5 \\
\hline 53 & - & - & . & . & & . & 121 & 121 & . & $<$ & 5 & 5412 & & \\
\hline 54 & . & - & - & - & & - & 122 & 134 & . & $<$ & 5 & . & $<$ & 5 \\
\hline 55 & 102 & 175 & $<10$ & $=$ & & . & 123 & . & - & & & . & & . \\
\hline 56 & 136 & 200 & $<10$ & . & & . & 124 & - & - & & . & . & & . \\
\hline 57 & $<200$ & 625 & $<10$ & 179 & $<$ & 5 & 125 & . & . & & 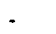 & . & & - \\
\hline 58 & $<\mathbf{2 0 0}$ & . & $<10$ & $.3,3 n$ & $<$ & 5 & 126 & 34 & . & く. & 10 & 2071 & < & 5 \\
\hline 59 & $<200$ & . & $<10$ & 348 & & 6 & 127 & 136 & . & $<$ & 6 & 2660 & $<$ & 5 \\
\hline 60 & . & . & . & - & & - & 128 & 110 & • & $<$ & 5 & - & $<$ & 5 \\
\hline 61 & - & - & - & . & & - & 129 & 1330 & 1525 & & 374 & 3177 & $<$ & 5 \\
\hline 62 & $<200$ & - & $<10$ & 369 & $<$ & 5 & 130 & . & . & & . & - & & . \\
\hline 63 & $<200$ & . & $<10$ & 443 & $<$ & 5 & 131 & . & . & & . & . & & . \\
\hline 64 & 272 & - & $<10$ & - & & - & 132 & . & . & & - & - & & - \\
\hline 65 & 306 & . & $<10$ & 554 & $<$ & 5 & 133 & 900 & . & & - & - & & . \\
\hline 66 & 29 & - & $<5$ & 942 & $<$ & .5 & 134 & 1000 & - & & . & . & & . \\
\hline 67 & - & - & - & . & & . & 1.35 & 9ดก & . & & . & . & & . \\
\hline 68 & . & . & - & . & & . & & & & & & & & \\
\hline
\end{tabular}


Table A-3
I

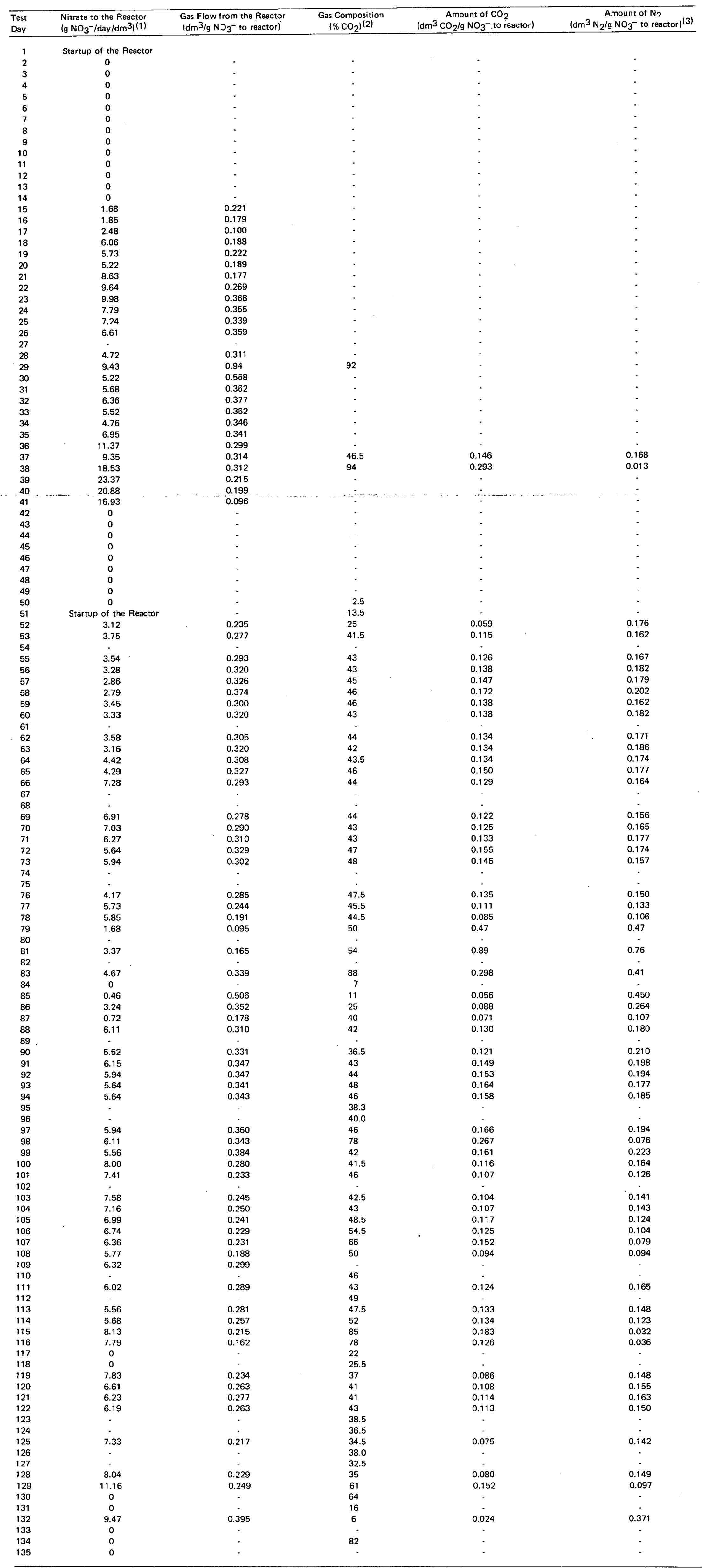

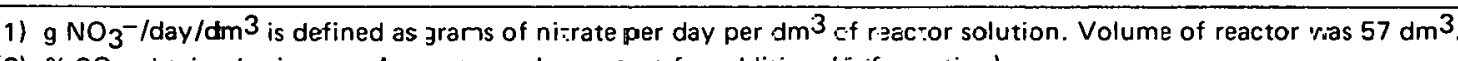

(3) Amount of $\mathrm{N}_{2}$ obtained by susstracting amourt of $\mathrm{CO}_{2}$ from the totil yas flow. 
Table A-4

REDUCTION OF NITRATE IN THE MINI II REACTOR

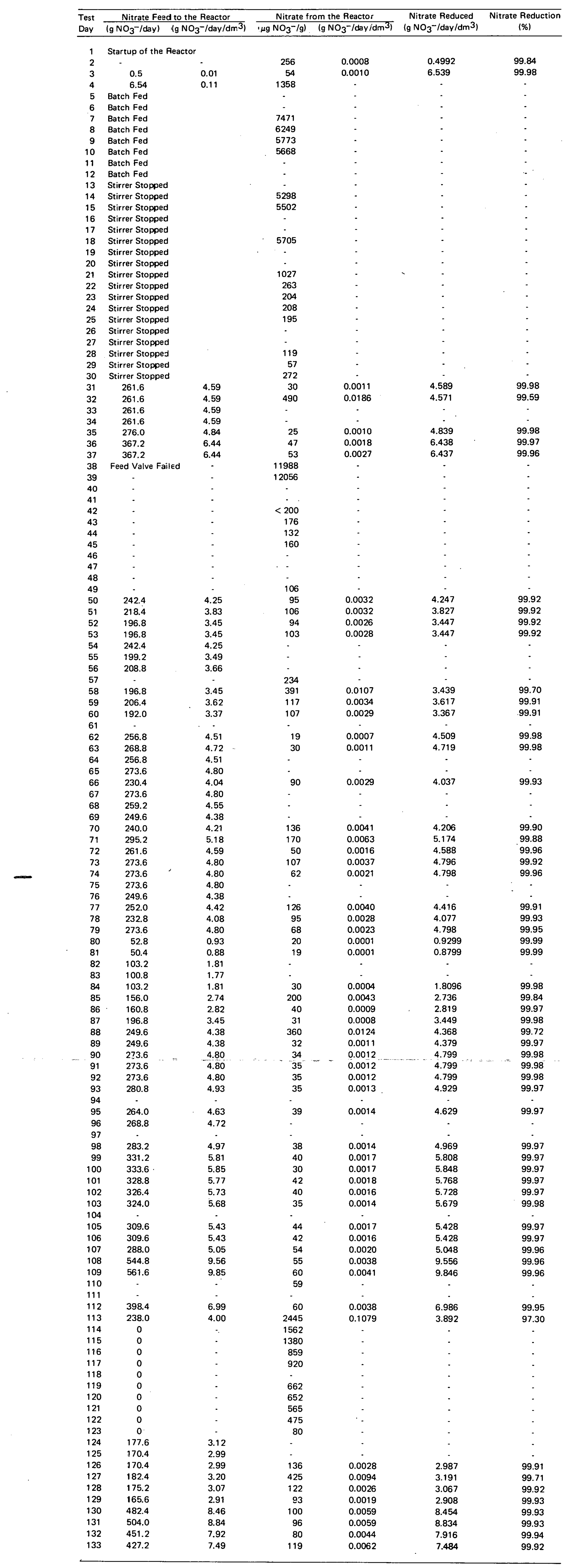


Table A-5

COMPOSITION OF LIQUID FROM THE MINI II REACTOR

\begin{tabular}{|c|c|c|c|c|c|c|c|c|c|c|c|}
\hline \multirow{2}{*}{$\begin{array}{l}\text { Test } \\
\text { Doy } \\
\end{array}$} & \multicolumn{5}{|c|}{ Analysis of Liquid from the Reactor $(\mu \mathrm{g} / \mathrm{g})$} & \multirow{2}{*}{$\begin{array}{l}\text { Test } \\
\text { Day }\end{array}$} & \multicolumn{5}{|c|}{ Analysis of Liquid from the Reactor $(\mu \mathrm{g} / \mathrm{g})$} \\
\hline & $\mathrm{NO}_{3}^{-}$ & TOC & $\mathrm{NO}_{2}^{--}$ & $\mathrm{NH}_{4}{ }^{+}$ & $\mathrm{PO}_{4}^{-3}$ & & $\mathrm{NO}_{3}^{-}$ & TOC & $\mathrm{NO}_{2}^{-}$ & $\mathrm{NH}_{4}^{+}$ & $\mathrm{PO}_{4}{ }^{-3}$ \\
\hline 1 & Startup o & the Reac & & & & 68 & - & $\cdot$ & $\cdot$ & $\cdot$ & $\cdot$ \\
\hline 2 & 256 & - & 52 & 157 & $<5$ & 69 . & - & - & - & - & - \\
\hline 3 & 54 & - & 131 & 166 & $<5$ & 70 & 136 & . & $<5$ & - & $<5$ \\
\hline 4 & 1358 & - & 290 & 120 & $<5$ & 71 & 170 & 1930 & 1 & - & $<5$ \\
\hline 5 & - & - & $\cdot$ & $\cdot$ & - & 72 & 50 & - & $\cdot$ & $\cdot$ & - \\
\hline 6 & . & . & - & - & - & 73 & 107 & 1930 & $<5$ & - & $<5$ \\
\hline 7 & 7171 & - & 1651 & 388 & $<5$ & 74 & 62 & $\cdot$ & - & - & $\cdot$ \\
\hline 8 & 6249 & 1300 & 1484 & 526 & - & 75 & - & . & - & - & $\cdot$ \\
\hline 9 & 5773 & 3150 & 2465 & 508 & - & 76 & - & - & - & - & - \\
\hline 10 & 5668 & 3125 & 2070 & 490 & - & 77 & 126 & 1800 & $<5$ & - & $<5$ \\
\hline 11 & $\cdot$ & $\cdot$ & - & - & $\cdot$ & 78 & 95 & $\cdot$ & $\cdot$ & $\cdot$ & $\cdot$ \\
\hline 12 & - & - & - & - & • & 79 & 68 & - & - & - & - \\
\hline 13 & - & - & $*$ & - & $\cdot$ & 80 & 20 & & & . & - \\
\hline 14 & 5298 & 2550 & 2151 & 490 & . & 81 & 19 & - & . & . & . \\
\hline 16 & 6503 & 1625 & 369 & 11 & - & 87 & $=$ & $=$ & $\cdot$ & $\cdot$ & $\cdot$ \\
\hline 16 & - & - & - & - & - & 83 & - & - & - & - & . \\
\hline 17 & - & - & - & $\cdot$ & . & 84 & 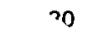 & - & - & . & - \\
\hline IH & 5715 & 2950 & fon & an & 0 & 85 & $2 n n$ & 190 & - & $\cdot$ & $\cdot$ \\
\hline $1 y$ & - & . & $=$ & - & - & the & 411 & 750 & $<i$ & - & 50 \\
\hline 20 & - & - & - & - & - & 87 & 31 & 260 & $<5$ & . & - \\
\hline 21 & 1027 & 1800 & $<10$ & 554 & $<5$ & 88 & 360 & $\cdot$ & - & $\cdot$ & 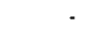 \\
\hline 22 & 263 & 1675 & $<5$ & 554 & $<5$ & 89 & 32 & $\cdot$ & - & $\therefore$ & $\cdot$ \\
\hline 23 & 204 & 1675 & $<5$ & 351 & $<5$ & 90 & 34 & . & - & - & $\cdot$ \\
\hline 24 & 200 & 1550 & $<5$ & 647 & $<5$ & 91 & 36 & - & - & . & $\cdot$ \\
\hline 25 & 195 & 1250 & $<5$ & 647 & $<.5$ & 92 & 35 & - & - & . & $\cdot$ \\
\hline 26 & $\cdot$ & - & $\cdot$ & $\cdot$ & - & 93 & 35 & - & - & - & $\cdot$ \\
\hline 27 & - & $\cdot$ & - & - & - & 94 & - & $\cdot$ & . & & \\
\hline 28 & 119 & 950 & $<10$ & 490 & $<5$ & 95 & 39 & 920 & 1 & - & - \\
\hline 29 & 57 & - & $<5$ & 508 & $<5$ & 96 & - & - & - & - & $\cdot$ \\
\hline 30 & 272 & 825 & $<5$ & 443 & $<5$ & 97 & - & . & - & - & $\cdot$ \\
\hline 31 & 30 & 900 & $<5$ & 416 & $<5$ & 98 & 38 & . & - & . & . \\
\hline 32 & 490 & 775 & 126 & 471 & $<5$ & 99 & 40 & 1600 & - & - & - \\
\hline 33 & $\cdot$ & - & - & $\cdot$ & . & 100 & 39 & - & - & - & - \\
\hline 31 & & & $=$ & - & - & 101 & 42 & - & & . & - \\
\hline 35 & 25 & 800 & $<5$ & 395 & $<5$ & 102 & 40 & - & - & - & - \\
\hline 36 & 47 & 600 & $<5$ & 610 & $<5$ & 103 & 35 & - & . & $\cdot$ & - \\
\hline 37 & 53 & 1100 & $<5$ & 600 & $<5$ & 104 & - & - & . & . & - \\
\hline 38 & 11988 & $\overline{5} 8 \overline{5} 0$ & 165 & 924 & $<5$ & 105 & 44 & - & - & - & - \\
\hline 39 & 12050 & 5050 & 112 & 022 & < 6 & 106 & 12 & 2100 & . & - & $\cdot$ \\
\hline 40 & - & $\cdot$ & - & - & . & 107 & 54 & . & - & . & $\cdot$ \\
\hline 41 & $\cdot$ & - & - & - & - & 108 & 55 & - & $\cdot$ & $\cdot$ & $\cdot$ \\
\hline 42 & $<200$ & 2400 & $<10$ & 379 & $<5$ & 109 & 60 & 2540 & . & . & - \\
\hline 43 & 176 & 2275 & 20 & 425 & $<5$ & 110 & 59 & - & - & . & - \\
\hline 44 & 132 & 2600 & $<5$ & 277 & $<5$ & 111 & $\cdot$ & - & . & - & $\cdot$ \\
\hline 45 & 160 & 2650 & $<5$ & 92 & $<5$ & 112 & 60 & - & - & - & - \\
\hline $4 h$ & 116 & 1995 & $<5$ & $<100$ & $<5$ & 113 & 2445 & 38550 & 14893 & . & $<5$ \\
\hline 47 & - & - & $\cdot$ & . & - & 114 & 1562 & $\cdot$ & 1790 & - & $\cdot$ \\
\hline 48 & . & - & - & - & - & 115 & 1380 & - & $\cdot$ & $\cdot$ & $\cdot$ \\
\hline 49 & 106 & 1850 & $<5$ & $<100$ & $<5$ & 116 & 857 & 3450 & 1314 & . & - \\
\hline 50 & 85 & 1650 & $<5$ & $<100$ & $<. b$ & 111 & $y 20$ & - & - & . & $\cdot$ \\
\hline 51 & 106 & 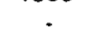 & $<5$ & - & $<5$ & 118 & - & - & - & - & $\cdot$ \\
\hline 52 & 94 & . & $<5$ & - & $<5$ & 119 & 662 & 3490 & 1102 & . & - \\
\hline 53 & IUS & $\cdot \quad-$ & $<5$ & - & - & 120 & 002 & 3400 & 1227 & . & . \\
\hline 54 & - & - & $\cdot$ & - & . & $i 21$ & 565 & $\cdot$ & . & . & $\cdot$ \\
\hline $3 b$ & - & - & - & - & - & 122 & 475 & . & . & . & $\cdot$ \\
\hline 56 & - & - & . & - & . & 123 & 80 & . & - & - & - \\
\hline 57 & 234 & - & $<5$ & - & $<5$ & 124 & . & - & - & . & - \\
\hline 58 & 391 & - & $<5$ & - & $<5$ & 126 & - & - & . & . & - \\
\hline 59 & 117 & - & $<5$ & - & $<5$ & 126 & 136 & - & $<5$ & . & $\cdot$ \\
\hline 60 & 107 & 1050 & $<5$ & - & $<5$ & 127 & 425 & 3840 & 8 & . & - \\
\hline 61 & $\cdot$ & . & - & - & $<5$ & $1 ? 8$ & 122 & 2980 & $<5$ & - & $\cdot$ \\
\hline 62 & 19 & - & - & - & . & 129 & 93 & 2800 & $\cdot$ & - & $\cdot$ \\
\hline 63 & 30 & - & - & - & - & 130 & 100 & - & . & . & $\cdot$ \\
\hline 64 & . & - & . & . & - & 131 & 96 & - & . & - & - \\
\hline 65 & . & . & . & . & . & $i 32$ & 80 & $\cdot$ & - & . & . \\
\hline 66 & 90 & - & - & - & - & 133 & 119 & 1580 & $<5$ & . & . \\
\hline 67 & - & - & - & . & - & & & & & & \\
\hline
\end{tabular}


Table A-6

MINI II GAS ANALYSES

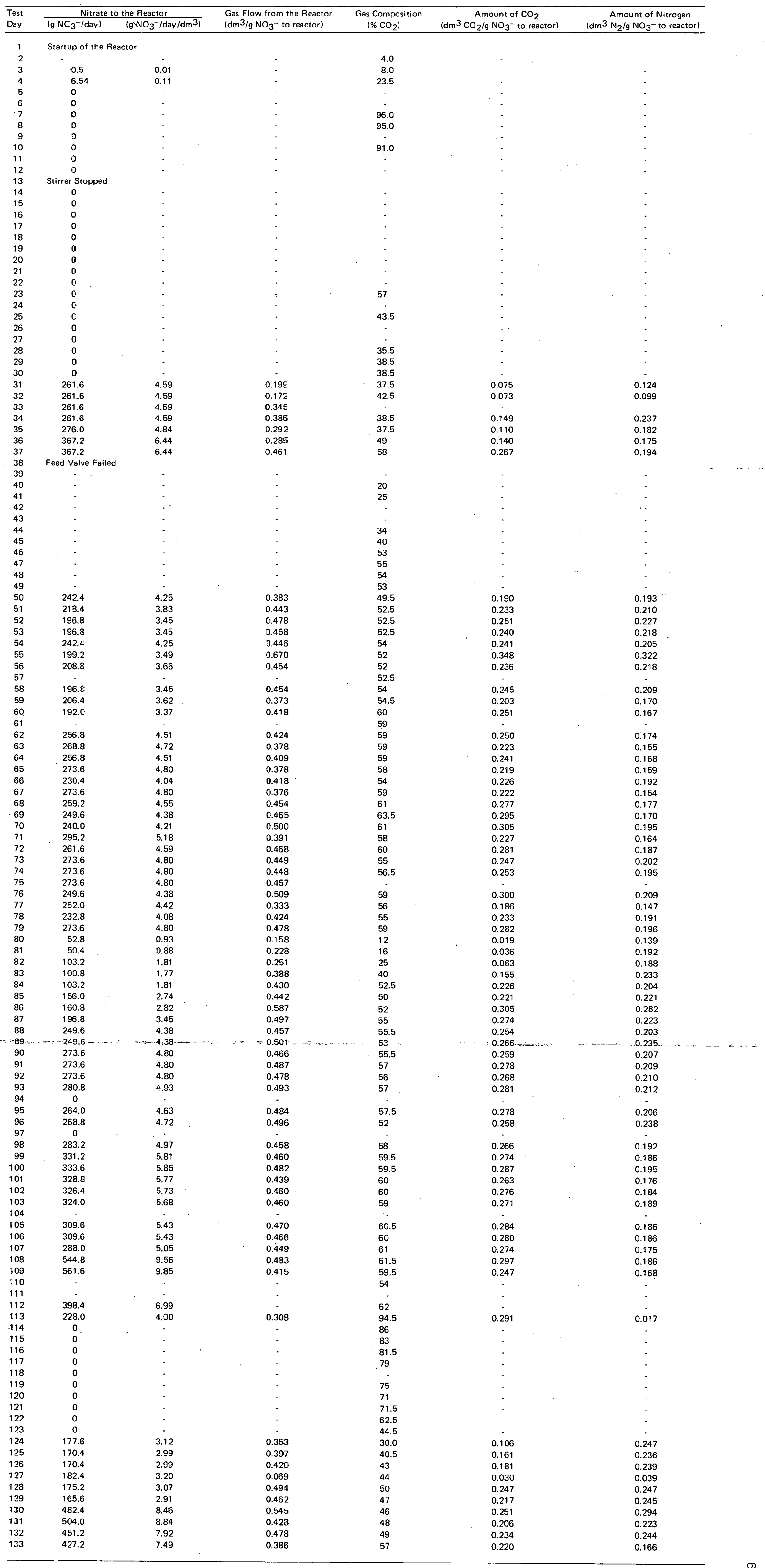


Table A.7

REDUC'ICIN OF NITF:ATE IN THE MINI III REACTOR

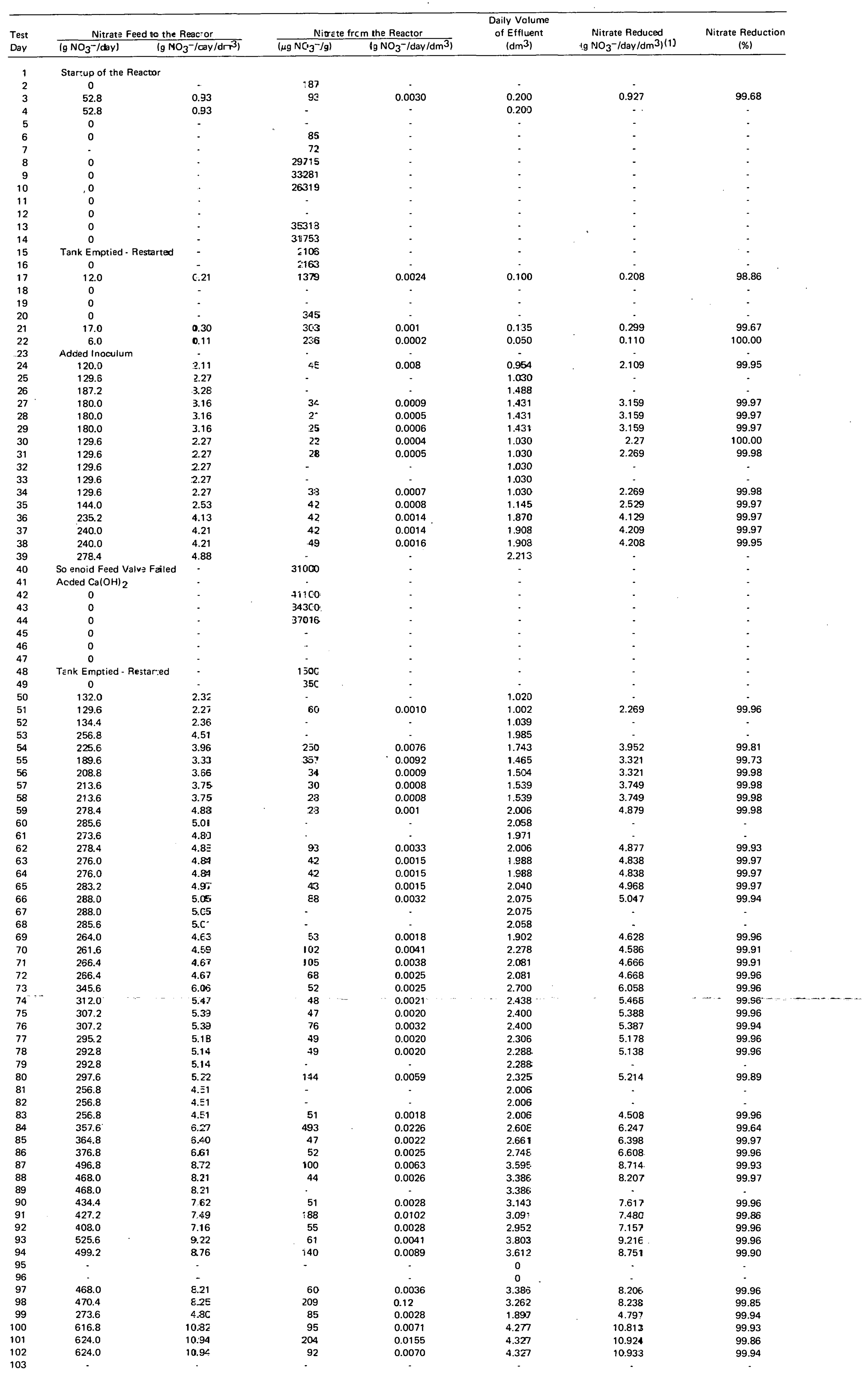


Table A-7 (Continued)

\begin{tabular}{|c|c|}
\hline Test & Nitrate \\
\hline Dav & $\left(\mathrm{gNO}_{3}^{-/ \text {day })}\right.$ \\
\hline 104 & 225.6 \\
\hline 105 & $2 \uparrow 8.4$ \\
\hline 106 & 360.0 \\
\hline 107 & 432.0 \\
\hline 108 & 451.2 \\
\hline 109 & 518.4 \\
\hline 110 & 492.J \\
\hline 111 & 482.4 \\
\hline 112 & 0 \\
\hline 113 & 0 \\
\hline 114 & 84.0 \\
\hline 115 & 216.0 \\
\hline 116 & 201.6 \\
\hline 117 & 146.4 \\
\hline 118 & 276.0 \\
\hline 119 & 273.6 \\
\hline 120 & 386.4 \\
\hline $121^{\circ}$ & 120.0 \\
\hline 122 & 0 \\
\hline 123 & 48.0 \\
\hline 124 & 72.0 \\
\hline 125 & 72.0 \\
\hline 126 & 74.4 \\
\hline 127 & 199.2 \\
\hline 128 & 196.8 \\
\hline 129 & 91.2 \\
\hline 130 & 309.6 \\
\hline 131 & 309.6 \\
\hline 132 & 309.6 \\
\hline 133 & 170.4 \\
\hline 134 & 427.2 \\
\hline 135 & 391.2 \\
\hline 136 & 432.0 \\
\hline :37 & 429.6 \\
\hline 138 & 415.2 \\
\hline 139 & 415.2 \\
\hline 140 & 415.2 \\
\hline$\lceil 41$ & 400.8 \\
\hline 142 & 408.0 \\
\hline 143 & 408.0 \\
\hline 144 & 132.0 \\
\hline 145 & 199.2 \\
\hline 146 & 192.0 \\
\hline 147 & 213.6 \\
\hline 148 & 369.6 \\
\hline 149 & 379.2 \\
\hline 150 & 364.8 \\
\hline 151 & 362.4 \\
\hline 152 & 369.6 \\
\hline 153 & 345.6 \\
\hline 154 & 328.8 \\
\hline 155 & 175.2 \\
\hline 156 & 374.4 \\
\hline 157 & 439.2 \\
\hline 158 & 372.0 \\
\hline 159 & 372.0 \\
\hline 160 & 379.2 \\
\hline $1 E 1$ & 360.0 \\
\hline $1 \in 2$ & 103.2 \\
\hline 163 & 127.2 \\
\hline 164 & 192.0 \\
\hline 165 & 232.8 \\
\hline 163 & 235.2 \\
\hline 167 & 235.2 \\
\hline 163 & 256.8 \\
\hline 169 & 232.8 \\
\hline 170 & 105.6 \\
\hline 171 & 0 \\
\hline 172 & 0 \\
\hline 173 & 0 \\
\hline 174 & 124.8 \\
\hline-1.72 & 249.6 \\
\hline $17 E$ & 388.8 \\
\hline 177 & 0 \\
\hline $17 \varepsilon$ & 48.0 \\
\hline 179 & 93.6 \\
\hline 180 & 93.6 \\
\hline 181 & 86.4 \\
\hline 182 & 67.2 \\
\hline 183 & 134.4 \\
\hline 184 & 103.2 \\
\hline 185 & 96.0 \\
\hline 186 & 88.8 \\
\hline 187 & 88.8 \\
\hline 188 & 88.8 \\
\hline 189 & 105.6 \\
\hline 190 & 96.0 \\
\hline 191 & 144.0 \\
\hline 192 & 134.4 \\
\hline 193 & 133.4 \\
\hline 194 & 133.4 \\
\hline 195 & 136.2 \\
\hline 196 & 208.8 \\
\hline 197 & 245.9 \\
\hline 198 & 239.1 \\
\hline
\end{tabular}

(1) Defined as grams of nitrate per day per $\mathrm{dm}^{3}$ of reactor solution. Volume of reactor was $57 \mathrm{dm}^{3}$. 
Table A-8

CON:POSITION OF LIQUID FFOM THE MINI III REACTOR

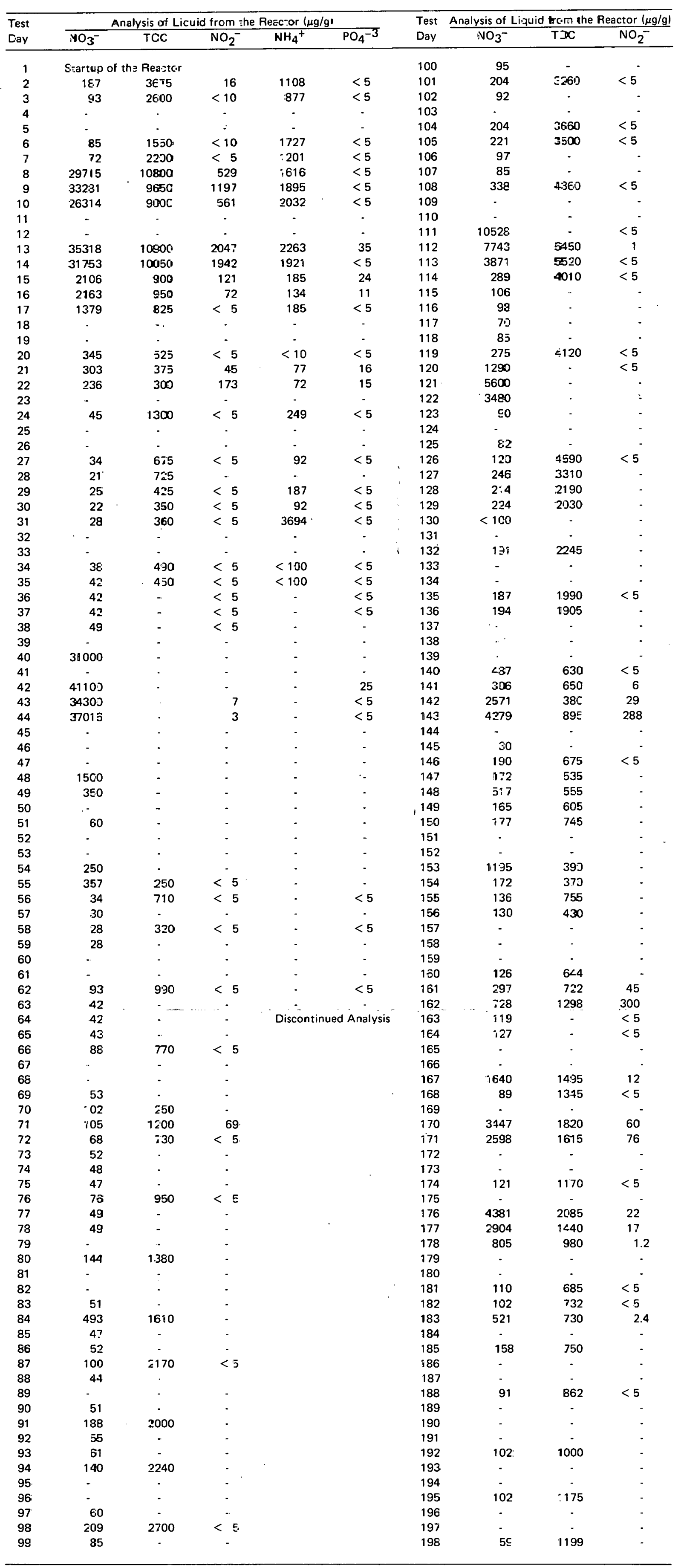


Table A.9

MINI III JAS ANALYSES

\begin{tabular}{|c|c|c|}
\hline $\begin{array}{l}\text { Test } \\
\text { Day }\end{array}$ & $\frac{\text { Nitrate }}{\text { (g NO }}$ & $\frac{\text { the Reac:or }}{\left(\mathrm{g} \mathrm{NO}_{3}-/ \mathrm{day} / \mathrm{dm}^{3}\right)}$ \\
\hline 1 & $\cdot$ & . \\
\hline 2 & - & - \\
\hline 3 & 0.93 & 52.8 \\
\hline 4 & 0.93 & 52.8 \\
\hline 5 & - & - \\
\hline 6 & . & . \\
\hline 7 & - & - \\
\hline 8 & - & - \\
\hline 9 & - & - \\
\hline 10 & - & . \\
\hline 11 & . & - \\
\hline 12 & - & - \\
\hline 13 & - & - \\
\hline 14 & & : \\
\hline 15 & Tank Emptied - & Restarted \\
\hline 16 & - & . \\
\hline 17 & 0.21 & 12 \\
\hline 18 & - & - \\
\hline 19 & 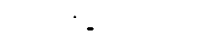 & - \\
\hline 20 & . & - \\
\hline 21 & 0.30 & 16.8 \\
\hline 22 & 0.11 & 2.6 \\
\hline 23 & Added Inoculun & \\
\hline 24 & 2.11 & 120 \\
\hline 25 & 2.27 & 129 \\
\hline 26 & 3.28 & 187 \\
\hline 27 & 3.16 & 180 \\
\hline 28 & 3.16 & 180 \\
\hline 29 & 3.16 & 180 \\
\hline 30 & 2.27 & 129 \\
\hline 31 & 129.6 & 2.29 \\
\hline 32 & 129.6 & 2.29 \\
\hline 33 & 129.6 & 2.27 \\
\hline 34 & 129.6 & 2.27 \\
\hline 35 & 144.0 & 2.53 \\
\hline 36 & 235.2 & 4.13 \\
\hline 37 & 240.0 & 4.21 \\
\hline 38 & 240.0 & 4.21 \\
\hline 39 & 278.4 & 4.88 \\
\hline 40 & Solenoid Feed & alve Failed \\
\hline 41 & Added $\mathrm{Ca}(\mathrm{OH})$ & \\
\hline 42 & 0 & - \\
\hline 43 & 0 & 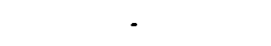 \\
\hline 44 & 0 & $\cdot$ \\
\hline 45 & 0 & 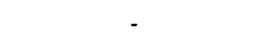 \\
\hline 46 & 0 & - \\
\hline 47 & 0 & \\
\hline 48 & Tank Emptied & Restarted \\
\hline 49 & 0 & \\
\hline 50 & 132.0 & 2.32 \\
\hline 51 & 129.6 & 2.27 \\
\hline 52 & 134.4 & 2.36 \\
\hline 53 & 256.8 & 4.51 \\
\hline 54 & 225.6 & 3.96 \\
\hline 55 & 189.6 & 3.33 \\
\hline 56 & 208.8 & 3.66 \\
\hline 57 & 213.6 & 3.75 \\
\hline 58 & 213.6 & 3.75 \\
\hline 59 & 278.4 & 4.88 \\
\hline 60 & 285.6 & 5.01 \\
\hline 61 & 273.6 & 4.80 \\
\hline 62 & 278.4 & 4.88 \\
\hline 63 & 276.0 & 4.84 \\
\hline 64 & 276.0 & 4.84 \\
\hline 65 & 283.2 & 4.97 \\
\hline 66 & 288.0 & 5.05 \\
\hline 67 & 288.0 & 5.05 \\
\hline 68 & 285.6 & 5.01 \\
\hline 69 & 264.0 & 4.63 \\
\hline 70 & 261.6 & 4.59 \\
\hline 71 & 266.4 & 4.67 \\
\hline 72 & 266.4 & 4.67 \\
\hline 73 & 338.4 & 6.06 \\
\hline 74 & 312.0 & 5.47 \\
\hline 75 & 307.2 & 5.39 \\
\hline 76 & 307.2 & 5.39 \\
\hline $7 i$ & 288.0 & 5.18 \\
\hline 78 & 292.8 & 5.14 \\
\hline 79 & 297.6 & 5.14 \\
\hline 80 & 297.6 & 5.22 \\
\hline 81 & 256.8 & 4.51 \\
\hline 82 & 256.8 & 4.51 \\
\hline 83 & 256.8 & 4.51 \\
\hline 84 & 357.6 & 6.29 \\
\hline 85 & 364.8 & 6.40 \\
\hline 85 & 376.8 & 6.61 \\
\hline 87 & 496.8 & 8.72 \\
\hline 88 & 468.0 & 8.21 \\
\hline 29 & 468.0 & 8.21 \\
\hline 90 & 434.4 & 7.62 \\
\hline 91 & 427.2 & 7.49 \\
\hline$\S 2$ & 408.0 & 7.16 \\
\hline$\leq 3$ & 525.6 & 9.22 \\
\hline 94 & 499.2 & 8.76 \\
\hline 95 & & 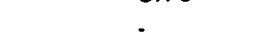 \\
\hline
\end{tabular}


Table A-9 (Continued:

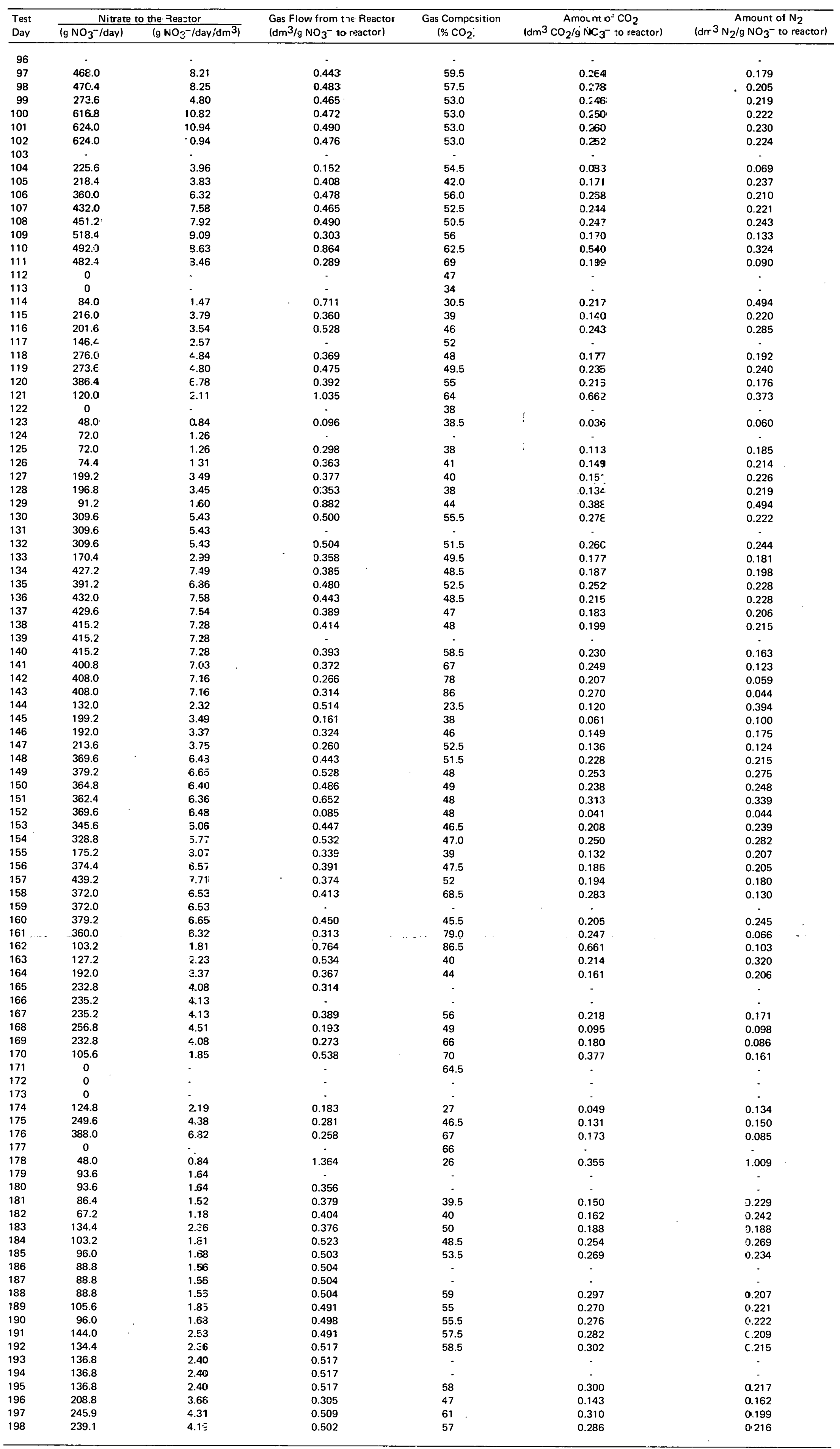


Table A-10

REDUCTION OF NITRATE IN THE MINI IV REACTOR

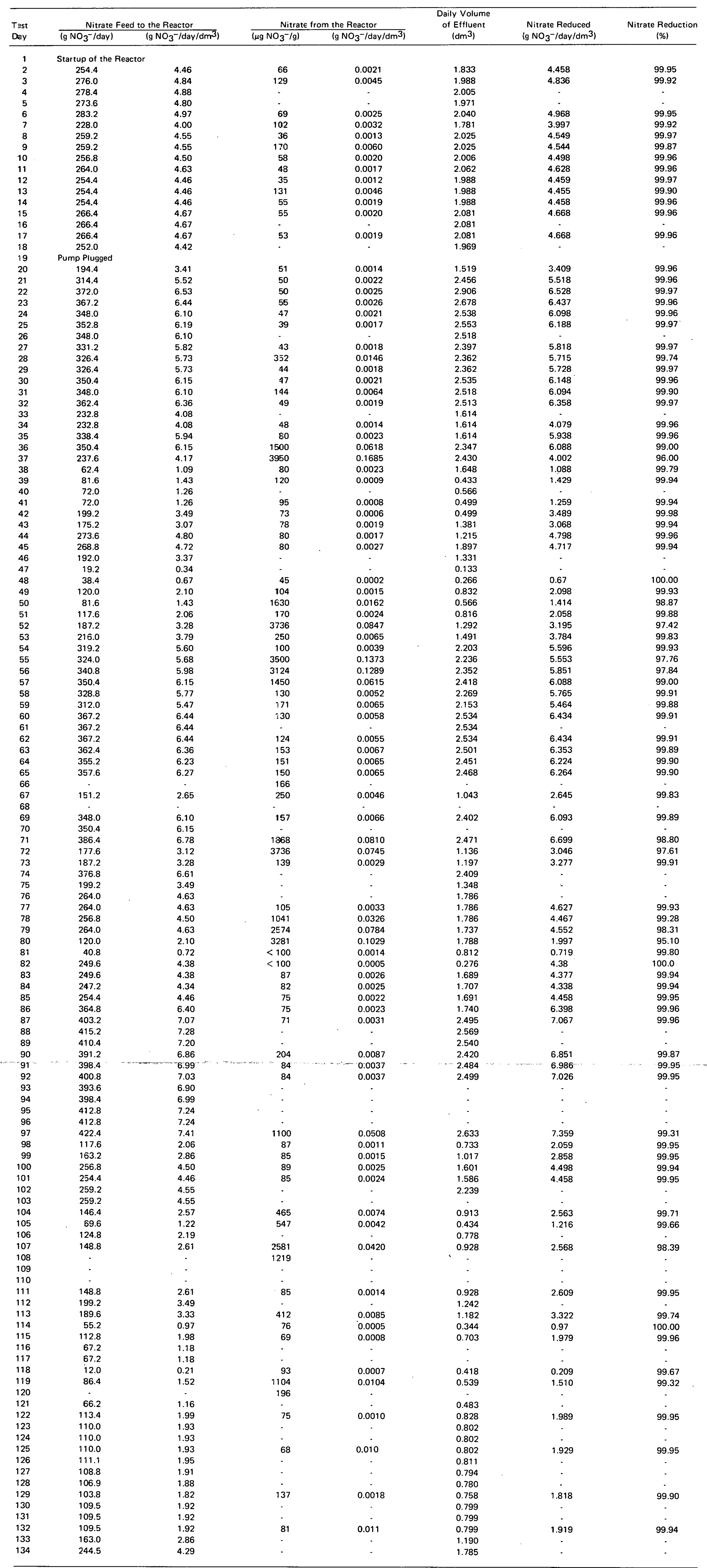


Table A-11

COMPOSITION OF LIQUID FROM THE MINI IV REACTOR

\begin{tabular}{|c|c|c|c|c|c|c|c|c|c|c|c|}
\hline \multirow{2}{*}{$\begin{array}{l}\text { Test } \\
\text { Day }\end{array}$} & \multirow{2}{*}{$\frac{\text { Analysis of }}{\mathrm{NO}_{3}-}$} & \multirow{2}{*}{ TOC } & \multirow{2}{*}{$\frac{\mathrm{NO}_{2}{ }^{-}}{}$} & \multirow{2}{*}{$\begin{array}{l}\mathrm{n} \text { the } \mathrm{Re} \\
\mathrm{NH}_{4}{ }^{+}\end{array}$} & \multirow{2}{*}{$\frac{\mathrm{PO}_{4}^{-}}{\mathrm{etor}(\mu \mathrm{g} /}$} & \multirow{2}{*}{$\begin{array}{l}\text { Test } \\
\text { Day }\end{array}$} & \multicolumn{5}{|c|}{ Analysis of Aqueous Effluent from the Reactor $(\mu \mathrm{g} / \mathrm{g})$} \\
\hline & & & & & & & $\mathrm{NO}_{3}^{-}$ & TOC & $\mathrm{NO}_{2}^{-}$ & $\mathrm{NH}_{4}{ }^{+}$ & $\mathrm{PO}_{4}^{-}$ \\
\hline 1 & Startup o & the Rea & ctor & & & 69 & 157 & 4680 & . & - & - \\
\hline 2 & 66 & - & - & - & - & 70 & - & - & . & - & - \\
\hline 3 & 129 & 1970 & $<5$ & - & . & 71 & 1868 & 4370 & - & - & - \\
\hline 4 & - & - & - & - & . & 72 & 3736 & 4780 & . & - & . \\
\hline 5 & - & - & - & - & - & 73 & 139 & $4270 / 2825^{(1)}$ & - & - & . \\
\hline 6 & 69 & . & - & - & - & 74 & - & - & . & - & - \\
\hline 7 & 102 & 1070 & 0.9 & . & . & 75 & . & . & . & . & . \\
\hline 8 & 36 & 1938 & $<5$ & - & - & 76 & - & . & - & - & - \\
\hline 9 & 170 & 850 & $<5$ & - & - & 77 & 105 & $2240 / 1210$ & - & - & . \\
\hline 10 & 58 & . & . & . & - & 78 & 1041 & $1570 / 1250$ & - & . & - \\
\hline 11 & 48 & - & - & . & - & 79 & 2574 & $1420 / 1205$ & . & . & . \\
\hline 12 & 55 & - & - & - & - & 80 & 3281 & $1105 / 1125$ & . & . & $=$ \\
\hline 13 & 131 & 1240 & $<5$ & - & . & 81 & $<100$ & . & . & - & - \\
\hline 14 & 55 & 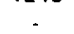 & . & . & . & n? & $5 \ln n$ & . & . & . & \\
\hline 15 & รุ. & & & & & 00 & 00 & 955/775 & . & . & - \\
\hline 16 & 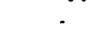 & - & - & - & - & 84 & 82 & $103 n / 781$ & - & . & . \\
\hline 17 & 53 & 1560 & 1.7 & . & . & 85 & 75 & $965 / 675^{(1)}$ & . & . & . \\
\hline 18 &. & . & . & . & . & 86 & 75 & 035 & . & . & . \\
\hline 19 & Pump Plu & & & & & 87 & 71 & $\overline{700}$ & & . & . \\
\hline 20 & 51 & . & - & - & - & 88 & . & 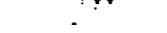 & - & . & . \\
\hline 21 & 50 & 3950 & . & - & . & 89 & - & . & . & - & - \\
\hline 22 & 50 & . & - & . & . & 90 & 204 & 240 & . & . & . \\
\hline 23 & 55 & - & - & - & - & 91 & 84 & $542 / 358$ & . & . & . \\
\hline 24 & 47 & 3290 & $\therefore 5$ & - & - & 32 & 84 & 355 & . & . & - \\
\hline 25 & 39 & - & 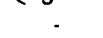 & . & - & 93 &. &. & - & & . \\
\hline 26 & . & - & . & - & - & 94 & . & . & . & - & . \\
\hline 27 & 43 & & . & . & . & 95 & . & . & . & . & - \\
\hline 28 & 352 & 2850 & - & - & . & 96 & - & - & . & . & . \\
\hline 29 & 44 &. & . & . & - & 97 & 1100 & $1272 / 1228$ & 634 & - & - \\
\hline 30 & 47 & . & - & . & - & 98 & 87 & $1072 / 988$ & $<5$ & . & . \\
\hline 31 & 144 & 3450 & - & - & - & 99 & 85 & $1085 / 1007$ & . & . & . \\
\hline 32 & 49 & 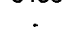 & - & . & - & 100 & 89 &.$/ 953$ & . & . & . \\
\hline 33 & - & - & . & - & . & 101 & 85 &.$/ 955$ & - & . & . \\
\hline 34 & 48 & . & - & - & . & 10? &. & . & 。 & . & . \\
\hline 35 & 80 & 3720 & 5 & . & $<5$ & 103 & . & - & . & . & - \\
\hline 36 & 1500 & - & . & . & $\therefore$ & 104 & 465 & $1125 /$. & 207 & - & . \\
\hline 37 & 3950 & - & . & - & . & 105 & 547 & $1075 / 1075$ & $<5$ & - & - \\
\hline 30 & 00 & วค९อ & $\leq 5$ & $=$ & . & 100 & . & . & . & - & - \\
\hline 39 & 120 & - & - & - & . & 107 & 2581 & $157 n /$. & 50 & . & . \\
\hline 40 & - & . & . & - & . & 108 & 1219 & $1415 /$ & 856 & . & - \\
\hline 41 & 95 & 4920 & $<5$ & - & - & 109 & 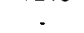 & . & . & - & - \\
\hline 42 & 13 & - & . & . & . & 110 & . & . & . & - & - \\
\hline 4.3 & 78 & - & . & - & . & 111 & 85 & $1045 / 790$ & $\leqslant 5$ & - & . \\
\hline 44 & 80 & - & . & - & - & 112 & - & - & 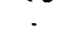 & . & . \\
\hline 45 & 80 & 3970 & $<5$ & . & . & 113 & 412 & $1025 / 859$ & 234 & . & . \\
\hline 16 & & & . & - & $=$ & 114 & 76 & $840 / 798$ & . & . & - \\
\hline 17 & & . & . & . & 2 & 115 & by & $140 / 10 /$ & $<b$ & . & . \\
\hline 18 & 10 & & & . & . & 19u & $=$ & - &. & . & . \\
\hline 49 & 404 & 4140 & $<5$ & . & - & 117 & . & - & . & - & . \\
\hline 50 & 1630 & 5520 & $<5$ & - & . & 118 & 93 & $750 / 7.32$ & $<5$ & . & , \\
\hline 51 & $1 / 0$ & 5080 & $<5$ & - & . & 119 & 1104 & $942 / 990$ & 63 & - & . \\
\hline 62 & 3730 & . & $\div 5$ & . & $=$ & 120 & 196 & /68// $\angle 4$ & 121 & - & - \\
\hline 53 & 250 & - & . & - & . & 121 & . & . & . & . & . \\
\hline b4 & 100 & . & - & . & - & 122 & 75 & $888 /$ & . & - & . \\
\hline 55 & 3500 & - & - & - & $=$ & 123 &. & . & & & 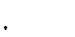 \\
\hline 56 & 3124 & 5660 & . & . & . & 124 & . & - & - & . & . \\
\hline 51 & 1400 & - & . & . & . & 125 & 68 & $1030 \%$ & $<5$ & . & . \\
\hline 58 & 130 & - & . & . & . & 126 &. & . & . & . & . \\
\hline 59 & 171 & 4290 & - & . & - & 127 & . & . & . & . & . \\
\hline 60 & 130 & . & & & - & 120 & - & - & - & . & . \\
\hline 61 & . & . & . & . & . & 129 & 137 & - & . & . & . \\
\hline 62 & 124 & - & . & . & & 130 & . & . & . & . & . \\
\hline 63 & 153 & 5360 & . & $\therefore$ & . & 131 & . & - & . & . & . \\
\hline 64 & 151 & 4630 & . & - & . & 132 & 81 & $1345 /-(1)$ & . & . & . \\
\hline 65 & 150 & 4590 & . & . & . & 133 &. & - & . & 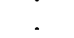 & . \\
\hline 66 & 166 & 4630 & - & - & - & 134 & . & . & - & - & - \\
\hline 67 & 250 & . & . & . & . & 135 & . & . & . & - & - \\
\hline 68 & - & . & . & . & . & & & & & & \\
\hline
\end{tabular}

(1) Acetate carbon. 
Table A-12

MINI IV GAS ANALYSES

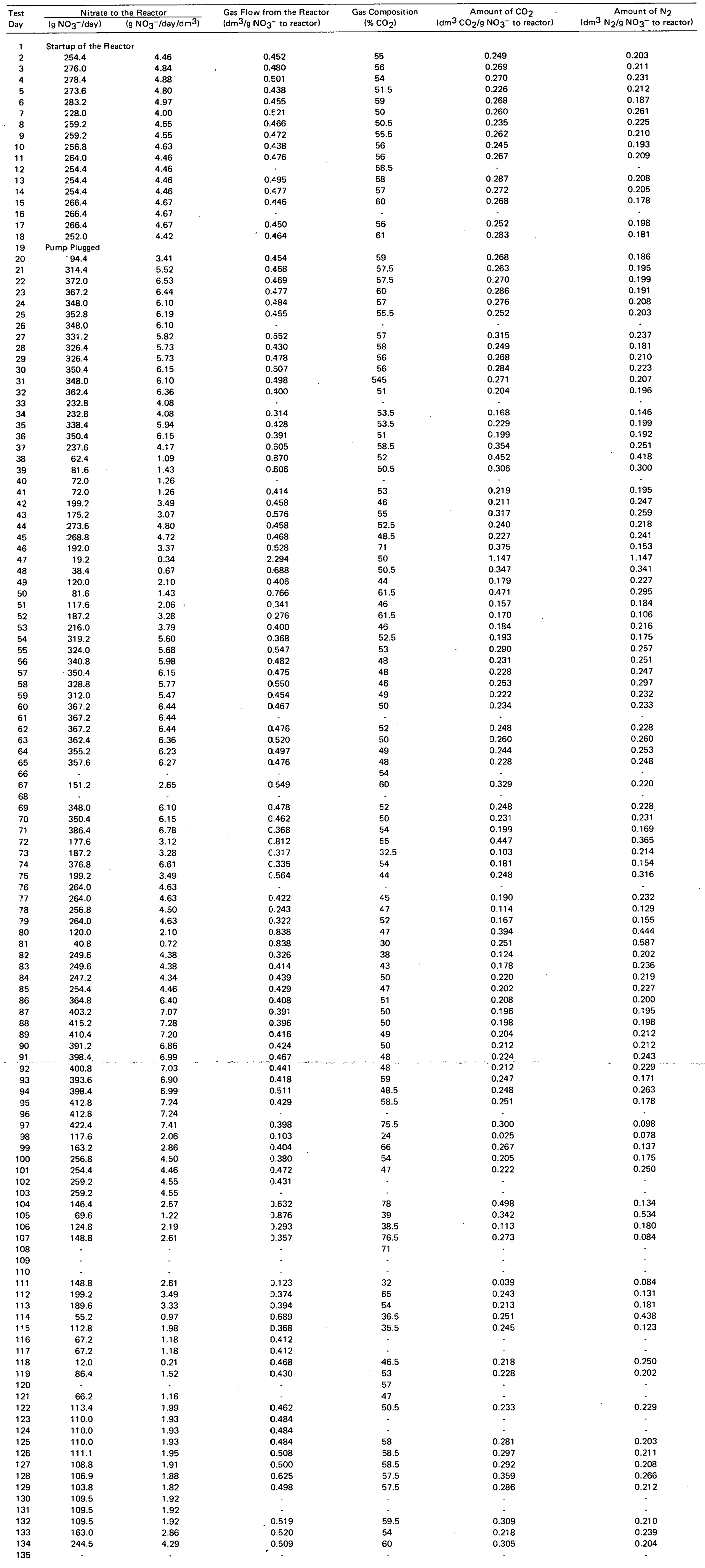


Table A.13

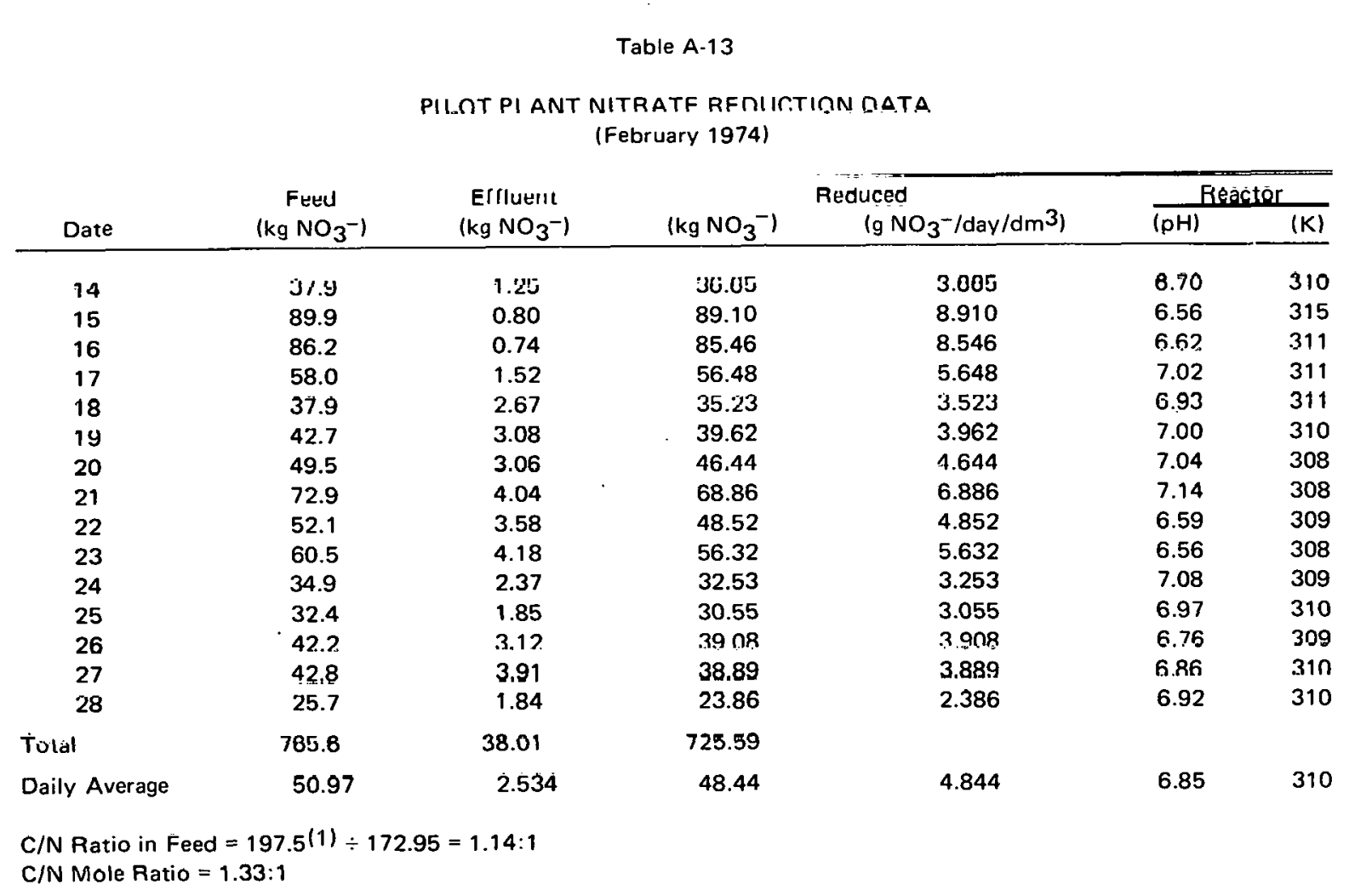

(1) Total organic carbon initially present tlus additions during month.

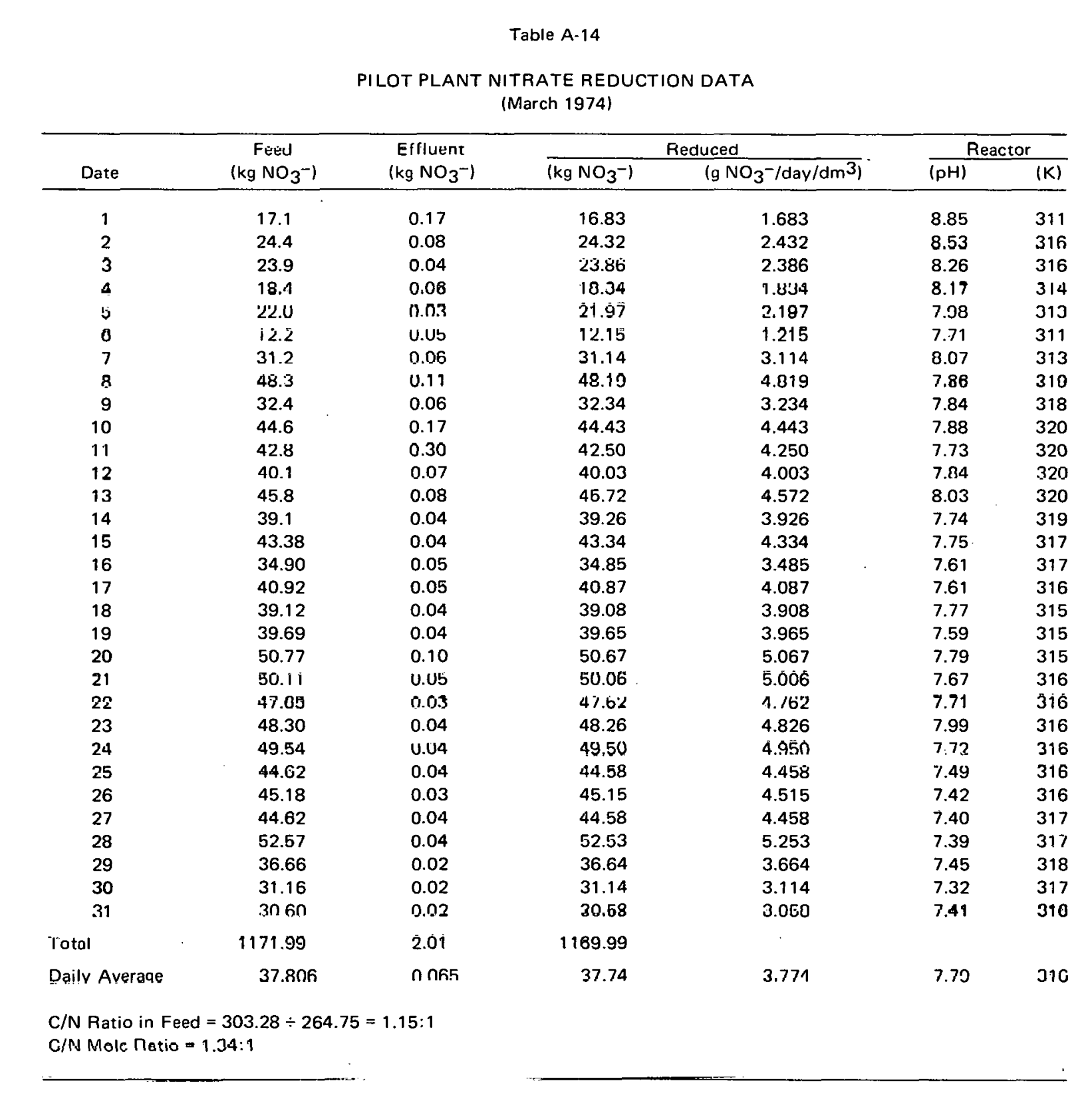

Table A.15

PILOT PLANT NITRATE REDUCTION DATA

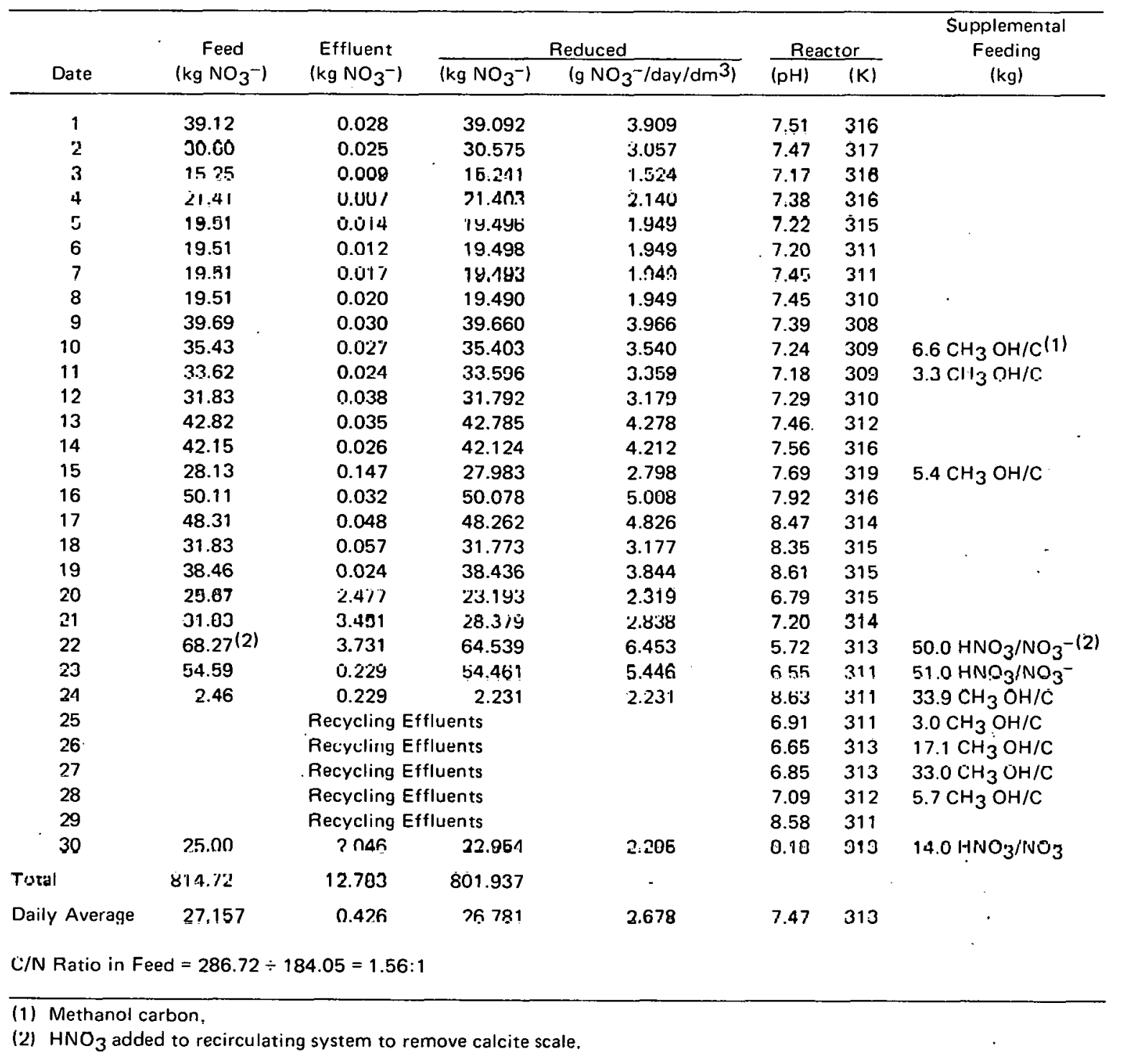


Table A.16

\begin{tabular}{|c|c|c|c|c|c|c|c|}
\hline \multirow[b]{2}{*}{ Date } & \multicolumn{6}{|c|}{$\begin{array}{l}\text { Table A-16 } \\
\text { NiTRATE REDUCTION DATA } \\
\text { (May 1974) }\end{array}$} & \multirow{3}{*}{ 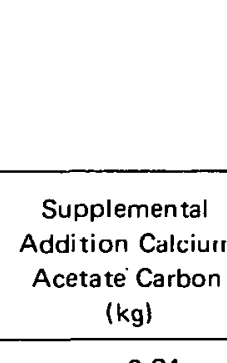 } \\
\hline & $\begin{array}{l}\text { Feed } \\
\left(\mathrm{kg} \mathrm{N}_{3}{ }^{-1}\right)\end{array}$ & $\begin{array}{l}\text { EElffuent } \\
\left(\mathrm{kg} \mathrm{N}_{3} \mathrm{NO}_{3}\right)\end{array}$ & \multicolumn{2}{|c|}{ 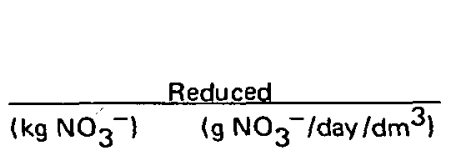 } & \multicolumn{2}{|c|}{$\frac{\text { Reactor }}{(\mathrm{pH}) \quad(\mathrm{K})}$} & \\
\hline 1 & $9.8^{111}$ & Reeycling & $5.7^{(2)}$ & 0.575 & 8.22 & 315 & \\
\hline$\frac{2}{3}$ & 13.3 & $\begin{array}{l}\text { EEffleut } \\
\text { Effluent }\end{array}$ & $\begin{array}{l}5.75 \\
5.75\end{array}$ & $\begin{array}{l}0.575 \\
0.575\end{array}$ & $\begin{array}{l}9.32 \\
9.28\end{array}$ & $\begin{array}{l}336 \\
316\end{array}$ & \\
\hline $\begin{array}{r}4 \\
5\end{array}$ & 7.1 & $\begin{array}{l}\text { EEflfuent } \\
\text { Effluent }\end{array}$ & $\begin{array}{l}5.75 \\
5.75\end{array}$ & $\begin{array}{l}0.575 \\
0.575\end{array}$ & $\begin{array}{l}8.43 \\
7.72\end{array}$ & $\begin{array}{l}311 \\
315\end{array}$ & \\
\hline & & 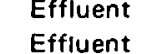 & 5.7.75 & $\begin{array}{l}0.575 \\
0.575\end{array}$ & $\begin{array}{l}7.06 \\
6.69\end{array}$ & 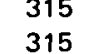 & \\
\hline 8 & 3.7 & $\begin{array}{l}\text { EEfluent } \\
\text { Eftuent }\end{array}$ & 5.75 & . 0.575 & $\begin{array}{l}0.09 \\
7.49\end{array}$ & 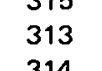 & $\begin{array}{l}. .73 \\
0.73\end{array}$ \\
\hline $\begin{array}{c}9 \\
10\end{array}$ & $\begin{array}{l}2.0 \\
1.7 \\
1.7\end{array}$ & $\begin{array}{l}\text { EEffluent } \\
\text { Effluent }\end{array}$ & 5.74 & $\begin{array}{l}0.575 \\
0.574\end{array}$ & $\begin{array}{l}7.06 \\
7.10\end{array}$ & $\begin{array}{l}314 \\
310\end{array}$ & $\begin{array}{l}0.52 \\
4.54\end{array}$ \\
\hline 11 & $\begin{array}{l}3.3 \\
4.6\end{array}$ & $\begin{array}{l}\text { Efffluent } \\
\text { Eftlifent }\end{array}$ & 5.74 & $\begin{array}{l}0.574 \\
0.574\end{array}$ & 7.92 & $\begin{array}{l}311 \\
3314\end{array}$ & $\begin{array}{r}12.12 \\
2.85 \\
-12\end{array}$ \\
\hline 13. & 年, 17.71 & $\begin{array}{l}\text { Etwluent } \\
0.002\end{array}$ & $\begin{array}{l}5.74 \\
5.74 \\
.7202\end{array}$ & 0.574 & $\begin{array}{l}8.04 \\
8.04\end{array}$ & $\begin{array}{l}314 . \\
312 \\
312\end{array}$ & 年. \\
\hline $\begin{array}{l}15 \\
16\end{array}$ & 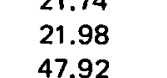 & $\begin{array}{l}0.249 \\
0.249\end{array}$ & $\begin{array}{l}21,731 \\
21.731 \\
1.05\end{array}$ & $\begin{array}{l}2.173 \\
2.1705 \\
205\end{array}$ & $\begin{array}{l}1.60 \\
7.45 \\
725\end{array}$ & $\begin{array}{l}312 \\
313 \\
313\end{array}$ & $\therefore$ \\
\hline 17 & 4.8 & $\begin{array}{l}\text { Reycting } \\
\text { Resycting }\end{array}$ & $\begin{array}{l}14.055 \\
14.055\end{array}$ & $\begin{array}{l}1.405 \\
1.405\end{array}$ & $\begin{array}{l}7.35 \\
6.88\end{array}$ & 311 & 3.08 \\
\hline $\begin{array}{l}18 \\
19\end{array}$ & & $\begin{array}{l}\text { Reyccing } \\
0.028\end{array}$ & $\begin{array}{l}14.055 \\
14.055\end{array}$ & $\begin{array}{l}1.405 \\
1.405 \\
-10\end{array}$ & $\begin{array}{l}7.53 \\
7.69\end{array}$ & $\begin{array}{l}313 \\
313\end{array}$ & $\begin{array}{l}4.80 \\
5.31\end{array}$ \\
\hline 20 & $\begin{array}{l}28.47 \\
24.27\end{array}$ & $\begin{array}{l}0.051 \\
0.055\end{array}$ & $\begin{array}{l}28.419 \\
24.155\end{array}$ & $\begin{array}{l}2.841 \\
2445\end{array}$ & 7.12 & 311 & 6.73 \\
\hline & 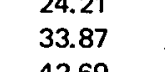 & 0.055 & $\begin{array}{l}24.155 \\
33.815 \\
3.51\end{array}$ & 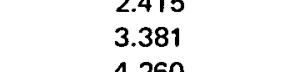 & $\begin{array}{l}6.12 \\
6.96\end{array}$ & $\begin{array}{l}312 \\
313\end{array}$ & 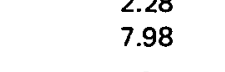 \\
\hline 24 & $\begin{array}{l}4269 \\
16.62\end{array}$ & $\begin{array}{l}0.089 \\
0.846\end{array}$ & $\begin{array}{l}42.601 \\
15.774\end{array}$ & $\begin{array}{l}4.260 \\
1.577\end{array}$ & $\begin{array}{l}6.78 \\
6.74\end{array}$ & $\begin{array}{l}\begin{array}{l}313 \\
315\end{array} \\
\end{array}$ & \\
\hline $\begin{array}{l}25 \\
26\end{array}$ & $\begin{array}{l}23.18 \\
3809\end{array}$ & $\begin{array}{l}0.516 \\
3.542\end{array}$ & $\begin{array}{l}22.634 \\
34.548\end{array}$ & $\begin{array}{l}2.263 \\
3.454 \\
2\end{array}$ & $\begin{array}{l}6.60 \\
6.20 \\
6.20\end{array}$ & $\begin{array}{l}313 \\
311\end{array}$ & $\begin{array}{l}6.50 \\
6.54\end{array}$ \\
\hline 27 & & 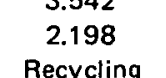 & $\begin{array}{l}9.452 \\
6.020\end{array}$ & $\begin{array}{l}0.945 \\
0.602\end{array}$ & $\begin{array}{l}5.99 \\
6.09\end{array}$ & $\begin{array}{l}311 \\
3314\end{array}$ & 6.84 \\
\hline & & $\begin{array}{l}\text { Reycling } \\
\text { Recyling }\end{array}$ & 6.020 & 0.602 & 5.97 & 310 & \\
\hline $\begin{array}{l}30 \\
31\end{array}$ & 3.7 & $\begin{array}{l}\text { Reycung } \\
\text { Reycling }\end{array}$ & $\begin{array}{l}0.020 \\
6.020\end{array}$ & $\begin{array}{l}0.602 \\
0.602\end{array}$ & $\begin{array}{l}8.15 \\
7.73\end{array}$ & 310 & 14.80 \\
\hline Total & 393.40 & 7.072 & 386.328 & & & & 101.39 \\
\hline Daily Average & 1269 & 0.228 & 12.462 & 1.246 & 7.36 & 313 & \\
\hline $\mathrm{C} / \mathrm{NRe}_{\mathrm{f}}$ & $d=18.90 \%$ & $8.87=2.12: 1$ & & & & & \\
\hline
\end{tabular}

Table A.17

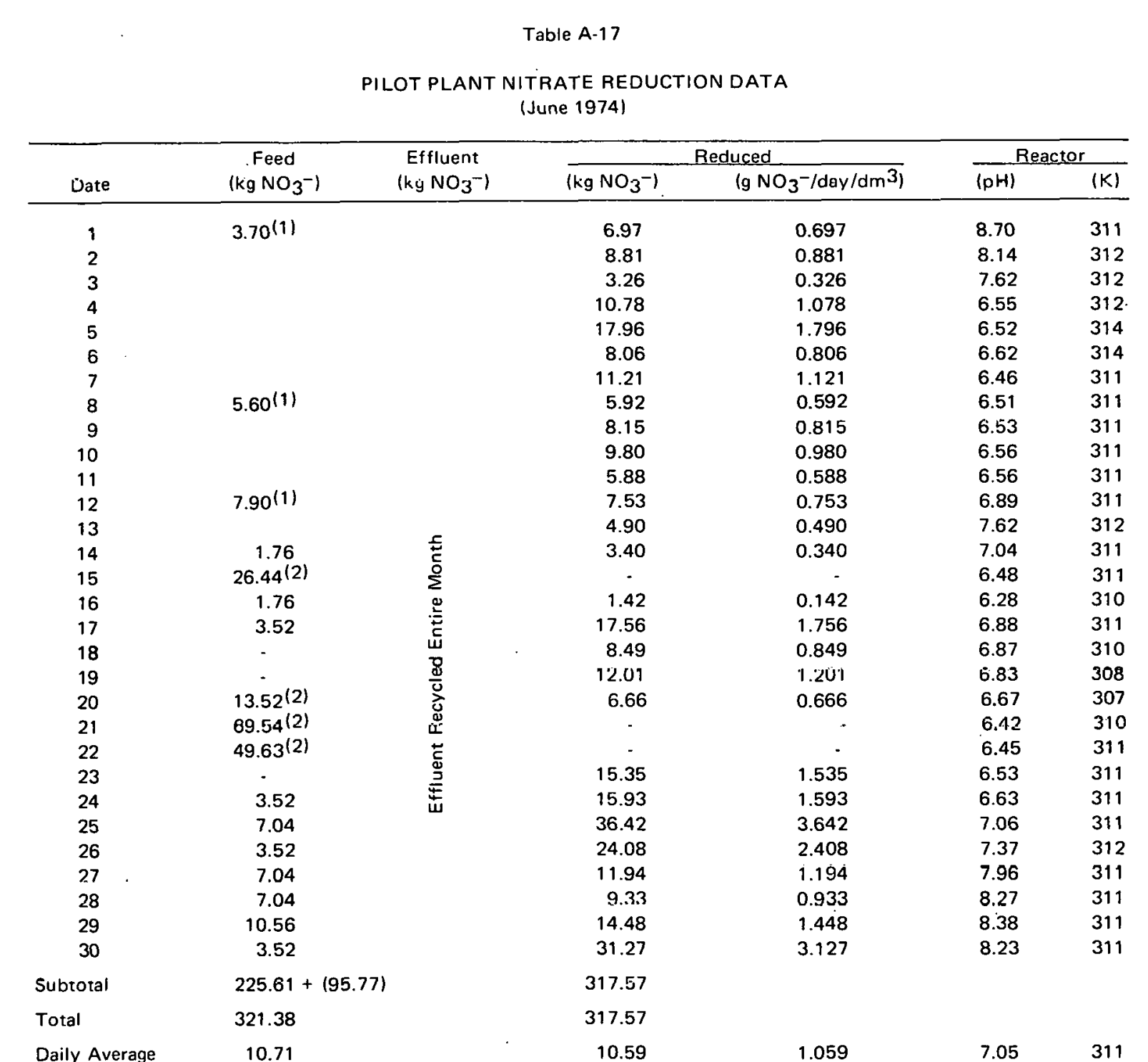

CIN Ratio in Feed $=12666-7260=179$

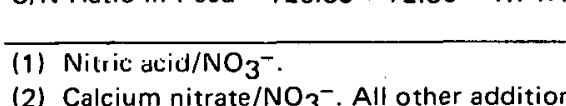

Table A.18

PILOT PLANT NITRATE REDUCTION DATA
IJUYY 1970 )

\begin{tabular}{|c|c|c|c|c|c|c|}
\hline \multirow[b]{2}{*}{ Date } & \multicolumn{4}{|c|}{$\begin{array}{l}\text { PILOT PLANT NITRATE REDUCTION DATA } \\
\text { (July 1974) }\end{array}$} & \multirow{2}{*}{\multicolumn{2}{|c|}{$\frac{\text { Reactor }}{(\text { DH }}$}} \\
\hline & \begin{tabular}{|c|c|c|} 
Feed \\
$\left(\mathrm{kg} \mathrm{NO}_{3}-1\right.$
\end{tabular} & $\begin{array}{c}\text { Effluent } \\
\left(\mathrm{kgNO}_{3}{ }^{-1}\right.\end{array}$ & $\overline{\left(\mathrm{IkgNO}_{3}-1\right.}$ & 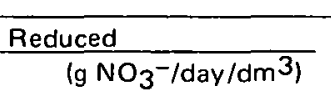 & & \\
\hline 1 & $5.28(1)$ & & 2.99 & 0.299 & 8.32 & \\
\hline & $\begin{array}{l}8.80 \\
.895\end{array}$ & & $\begin{array}{l}10.699 \\
10.69\end{array}$ & $\begin{array}{l}1.069 \\
1.069\end{array}$ & 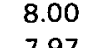 & $\begin{array}{l}313 \\
313 \\
313\end{array}$ \\
\hline $\begin{array}{l}3 \\
4\end{array}$ & $\begin{array}{l}7.95 \\
13.40 \\
01\end{array}$ & & $\begin{array}{l}1.357 \\
10.58\end{array}$ & $\begin{array}{l}1.357 \\
1.058 \\
-1058\end{array}$ & $\begin{array}{l}7.97 \\
8.25 \\
-\end{array}$ & $\begin{array}{l}313 \\
313 \\
313\end{array}$ \\
\hline $\begin{array}{l}5 \\
6\end{array}$ & $\mid \begin{array}{c}56.62(2) \\
6.81 \\
6\end{array}$ & & $\begin{array}{r}4.17 \\
16.61\end{array}$ & $\begin{array}{l}0.417 \\
1.661 \\
0\end{array}$ & $\begin{array}{l}7.34 \\
7.78 \\
\end{array}$ & $\begin{array}{l}\begin{array}{l}312 \\
312\end{array} \\
312\end{array}$ \\
\hline $\begin{array}{l}7 \\
8\end{array}$ & 9.09 & & $\begin{array}{l}5.87 \\
0.61\end{array}$ & $\begin{array}{l}0.587 \\
0.061\end{array}$ & $\begin{array}{l}7.31 \\
7.21\end{array}$ & $\begin{array}{l}312 \\
314\end{array}$ \\
\hline $\begin{array}{r}9 \\
10\end{array}$ & $\begin{array}{r}6181 \\
11160\end{array}$ & & $\begin{array}{l}0.93 \\
0.07\end{array}$ & $\begin{array}{l}0.093 \\
0.007\end{array}$ & $\begin{array}{l}7.05 \\
7.07\end{array}$ & $\begin{array}{l}312 \\
312\end{array}$ \\
\hline 11 & $\begin{array}{l}13.63 \\
3.27\end{array}$ & & $\begin{array}{l}1.23 \\
0.65\end{array}$ & $\begin{array}{l}0.123 \\
0.005\end{array}$ & $\begin{array}{l}6.90 \\
6.80\end{array}$ & $\begin{array}{l}313 \\
312\end{array}$ \\
\hline $\begin{array}{l}13 \\
14\end{array}$ & $\begin{array}{l}6.81 \\
2.27\end{array}$ & & & & & $\begin{array}{l}312 \\
312\end{array}$ \\
\hline $\begin{array}{l}15 \\
16\end{array}$ & 4.54 & 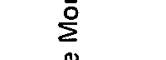 & & & & $\begin{array}{l}312 \\
312 \\
312\end{array}$ \\
\hline & $\begin{array}{l}6.81 \\
5.50\end{array}$ & 毵 & $\begin{array}{l}1.50 \\
9.57\end{array}$ & $\begin{array}{l}0.150 \\
0.957\end{array}$ & $\begin{array}{l}6.91 \\
700\end{array}$ & 312 \\
\hline 19 & $\begin{array}{l}5.50 \\
2.50 \\
2501\end{array}$ & ّँ & $\begin{array}{l}4.57(3) \\
.957\end{array}$ & $\begin{array}{l}0.957 \\
0.457 \\
.045\end{array}$ & & $\begin{array}{r}312 \\
312 \\
2\end{array}$ \\
\hline 21 & & 育 & 4.58 & 0.458 & & $\begin{array}{l}311 \\
311 \\
\text {. }\end{array}$ \\
\hline $\begin{array}{l}22 \\
23\end{array}$ & . & 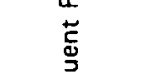 & $\begin{array}{l}4.58 \\
4.58\end{array}$ & $\begin{array}{l}0.458 \\
0.458\end{array}$ & & $\begin{array}{l}311 \\
311\end{array}$ \\
\hline 25 & 2.50 & 遥 & $\begin{array}{l}4.58 \\
4.58\end{array}$ & $\begin{array}{l}0.458 \\
0.458\end{array}$ & 7.00 & $\begin{array}{l}311 \\
312 \\
312\end{array}$ \\
\hline $\begin{array}{l}26 \\
27\end{array}$ & $\begin{array}{l}1.25 \\
1.25 \\
-1\end{array}$ & & $\begin{array}{l}4.58 \\
4.58\end{array}$ & $\begin{array}{l}0.458 \\
0.458\end{array}$ & & $\begin{array}{l}\begin{array}{l}311 \\
309\end{array} \\
309\end{array}$ \\
\hline${ }_{29}^{28}$ & & & $\begin{array}{l}4.58 \\
4.58\end{array}$ & $\begin{array}{l}0.458 \\
0.458\end{array}$ & & 311 \\
\hline $\begin{array}{l}30 \\
31\end{array}$ & $\begin{array}{l}2.5 \\
2.5\end{array}$ & & $\begin{array}{r}\begin{array}{r}4.58 \\
24.58\end{array} \\
\end{array}$ & $\begin{array}{l}0.458 \\
2.458 \\
\end{array}$ & $\begin{array}{l}7.98 \\
7.90\end{array}$ & $\begin{array}{l}312 \\
312 \\
-12\end{array}$ \\
\hline tiviat & $183.17-13.11$ & & 158.56 & & 7.30 & 313 \\
\hline ptal & 169.46 & & 158.56 & & & \\
\hline
\end{tabular}

\begin{tabular}{l|r} 
Total & 169.46 \\
Daily Average & 5.47
\end{tabular}

C/N Ratio in Feed

(1) Nitrate feed for the entire month, except on the 5 th, was scidified aluminum nitrate to simulatec concentrated raffinate
feed.

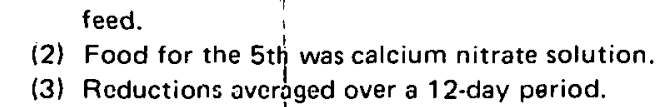




\section{Distribution}

Energy Research and Development Administration - Oak Ridge

Hibbitts, H.W.

Hickman, H. D.

Sieman, R. C.

Wing, J. F. (5)

Zachry, D. S.

\section{Los Alamos Scientific Laboratory}

Rohrer, D. M.

\section{Oak Rirdg̣e Găaseous Dịrfụsiụ! Plant}

Douglass, T. E.

Hartman, W. C.

Pashley, J. H.

Stief, S. S.

Wilcox, W. J., Jr

\section{Oak Ridge National Laboratory}

Auerbach, S. I. (20)

Francis. C. W. (20)

Sriffith, W. b.

Hancher, C. W.

Nelcon, D. J.

Struxness, E. G.

\section{Oak Ridge Y-12 Plant}

Avee, $\mathrm{H}$. $\mathrm{H}$.

Barkman, J. R.

Briscoe, O.W.

Burditt. R. B.

Buırkhart, I. F./Mietrish, W. C.

Clark, F. E.

Fraser, R. J.

Gary, W. E.

Jordan, R. G.

Kahl, K. G.
Keith, A.

Kite, H. T. (50)

Laggis, E. G.

Lundin, M. I.

Marrow, G. B.

McLendon, J. D.

Mee, W. T.

Mills, J. M., Jr

Napier, J. M. (5)

Parsens, J. A.

Phillips, L.R.

Sanders. M.

Schreyer, J. M./Schmitt, C. K.

Smith, R. D.

Speas, I. G.

Strohecker, J. W.

Stroud, D. D.

Weathersby, W. E.

Whitson, W. K.

Williams, R. D.

Yaggi, W. J./Googin, J. M.

$Y-12$ Centrạl Files (5)

$Y-12$ Central Filos (mastor cop' $y^{\prime}$ )

$\mathrm{Y}-12$ Central Files (route copy)

$Y 12$ Contral Filc3 ( $Y: 12$ RC)

Zerby, C. D.

7.ucker, D.

\section{Paducah Gaseous Diffusion Plant}

Baker, R. C.

Levin, R. W.

In addition, this report is distributed in accordance with the category UC-11, Environmental and Earth Sciences, as given in the USERDA Standard Distribution Lists for Unclassified Scientific and Technical Reports, TID-4500. 